\title{
Review \\ Unraveling How Tumor-Derived Galectins Contribute to Anti-Cancer Immunity Failure
}

\author{
Diego José Laderach ${ }^{1,2,3, * \mathbb{C}}$ and Daniel Compagno ${ }^{1,2}$ (D) \\ 1 Molecular and Functional Glyco-Oncology Laboratory, IQUIBICEN-CONICET, \\ Buenos Aires C1428BGA, Argentina; danielcompagno@qb.fcen.uba.ar \\ 2 Departamento de Química Biológica, Facultad de Ciencias Exactas y Naturales, Universidad de Buenos Aires, \\ Buenos Aires C1428EGA, Argentina \\ 3 Departamento de Ciencias Básicas, Universidad Nacional de Luján, Luján L6700, Argentina \\ * Correspondence: diegoladerach@qb.fcen.uba.ar
}

check for updates

Citation: Laderach, D.J.;

Compagno, D. Unraveling How

Tumor-Derived Galectins Contribute to Anti-Cancer Immunity Failure. Cancers 2021, 13, 4529. https:// doi.org/10.3390/cancers13184529

Academic Editor: Djordje

Atanackovic

Received: 17 July 2021

Accepted: 24 August 2021

Published: 9 September 2021

Publisher's Note: MDPI stays neutral with regard to jurisdictional claims in published maps and institutional affiliations.

Copyright: (c) 2021 by the authors. Licensee MDPI, Basel, Switzerland. This article is an open access article distributed under the terms and conditions of the Creative Commons Attribution (CC BY) license (https:/ / creativecommons.org/licenses/by/ $4.0 /)$.
Simple Summary: This review compiles our current knowledge of one of the main pathways activated by tumors to escape immune attack. Indeed, it integrates the current understanding of how tumor-derived circulating galectins affect the elicitation of effective anti-tumor immunity. It focuses on several relevant topics: which are the main galectins produced by tumors, how soluble galectins circulate throughout biological liquids (taking a body-settled gradient concentration into account), the conditions required for the galectins' functions to be accomplished at the tumor and tumor-distant sites, and how the physicochemical properties of the microenvironment in each tissue determine their functions. These are no mere semantic definitions as they define which functions can be performed in said tissues instead. Finally, we discuss the promising future of galectins as targets in cancer immunotherapy and some outstanding questions in the field.

Abstract: Current data indicates that anti-tumor T cell-mediated immunity correlates with a better prognosis in cancer patients. However, it has widely been demonstrated that tumor cells negatively manage immune attack by activating several immune-suppressive mechanisms. It is, therefore, essential to fully understand how lymphocytes are activated in a tumor microenvironment and, above all, how to prevent these cells from becoming dysfunctional. Tumors produce galectins- $1,-3,-7$, -8 , and -9 as one of the major molecular mechanisms to evade immune control of tumor development. These galectins impact different steps in the establishment of the anti-tumor immune responses. Here, we carry out a critical dissection on the mechanisms through which tumor-derived galectins can influence the production and the functionality of anti-tumor T lymphocytes. This knowledge may help us design more effective immunotherapies to treat human cancers.

Keywords: galectins; tumor immune evasion; cancer immunotherapy; lymphocyte homeostasis

\section{Introduction}

In humans, the immune system is constituted by approximately $10^{13} \mathrm{~T}$ lymphocytes at a given time [1]. However, lymphoid homeostasis is highly dynamic, depending on the continuous production of naïve cells in central hematopoietic organs, their activation, survival, and generation of immune memory in peripheral organs. Each of these processes depends on continuous biological signals that lymphocytes receive from their microenvironment [2] At a molecular level, multiple signaling pathways are involved in lymphocyte regulation. Although we only have a partial understanding of this subject, an extensive compendium of the literature supports galectins as being prominent actors in the regulation of immune homeostasis in both central and peripheral organs (as discussed below).

Currently, 12 human galectin members have been described and found in GenBank (https:/ / www.ncbi.nlm.nih.gov/genbank/; accessed on 15 July 2021). Galectins are involved in the regulation of different cellular processes, among which we can mention cell 
differentiation, cell adhesion and migration; gene transcription and RNA splicing; and cell cycle and apoptosis $[3,4]$. Such biological functions depend on their lectinic properties (recognition of $\mathrm{N}$-acetyllactosamine sequences displayed on the cell surface, in the extracellular matrix, or intracellular glycoconjugates) (Table 1). Besides, and studied to a lesser extent, they also depend on non-lectinic properties mediated by interactions of galectins with nucleic acids, proteins, lipids, and complex biomolecules (reviewed in [4], Table 1).

Interestingly, the expression profile of galectins is altered during several pathological conditions (expert opinions for each disease have been reviewed in [5-14]). In particular, the production of galectins- $1,-3,-7,-8$, and -9 is deregulated during tumorigenesis [15-17]. These galectins are detected in transformed cells and their associated stroma in various types of cancers $[18,19]$. In the latter case, it is not clear whether stromal cells produce galectins by themselves or take them up from neighboring transformed cells [20-22]. However, galectins play essential roles in controlling the tumor microenvironment properties independently of their cellular origin $[18,19]$. Notably, tumor-associated hypoxia and inflammation contribute to the deregulation of galectins expression [23-26]. As a consequence, increased levels of these galectins are detected in the sera of cancer patients. Until mid-2021, more than 55 independent studies have been recorded in this field (here, and due to space limitations, we only cite some examples on each galectin member [27-38]).

Increased galectins production in cancers has been proposed as a prognostic factor since they can easily be detected in the biological fluids and their expression in the tumor microenvironment generally predicts a poor clinical outcome for patients [15,19,39-41]. Besides being used as interesting biomarkers, these tumor-derived galectins display active roles in defining tumor progression. Despite the multiple influences these proteins have on the behavior of tumor cells (e.g., tumorigenesis, metastasis, and angiogenesis) [16], it is clear that they constitute an important strategy applied by tumors to evade an immune attack [42]. This review aims to deepen our knowledge on how galectins, abundantly produced by tumors, can impact the production, activation, and effector function of antitumor T lymphocytes; some of these processes occur at anatomic sites distant from the tumor (Figure 1). 
Table 1. The galectins' interactors and their impact on cancer immune escape.

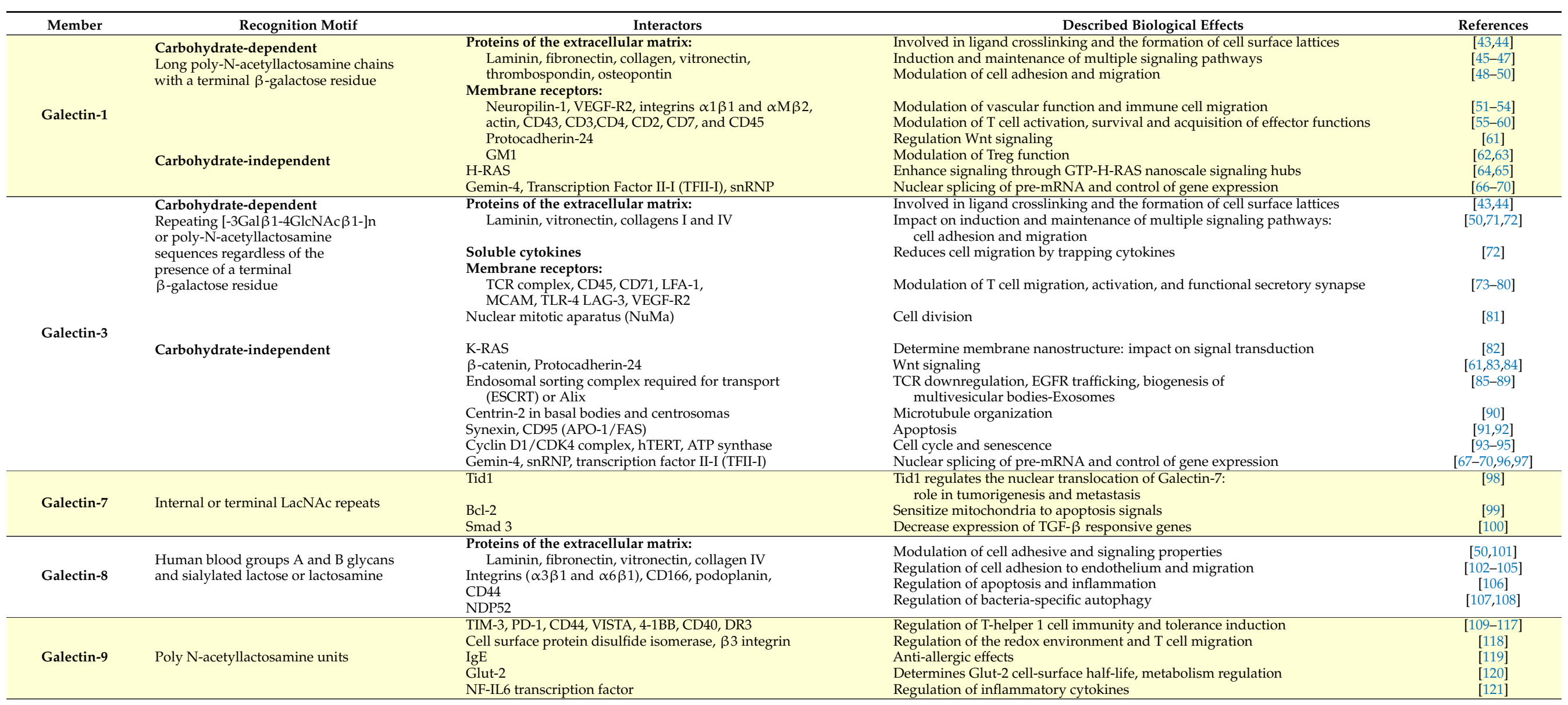




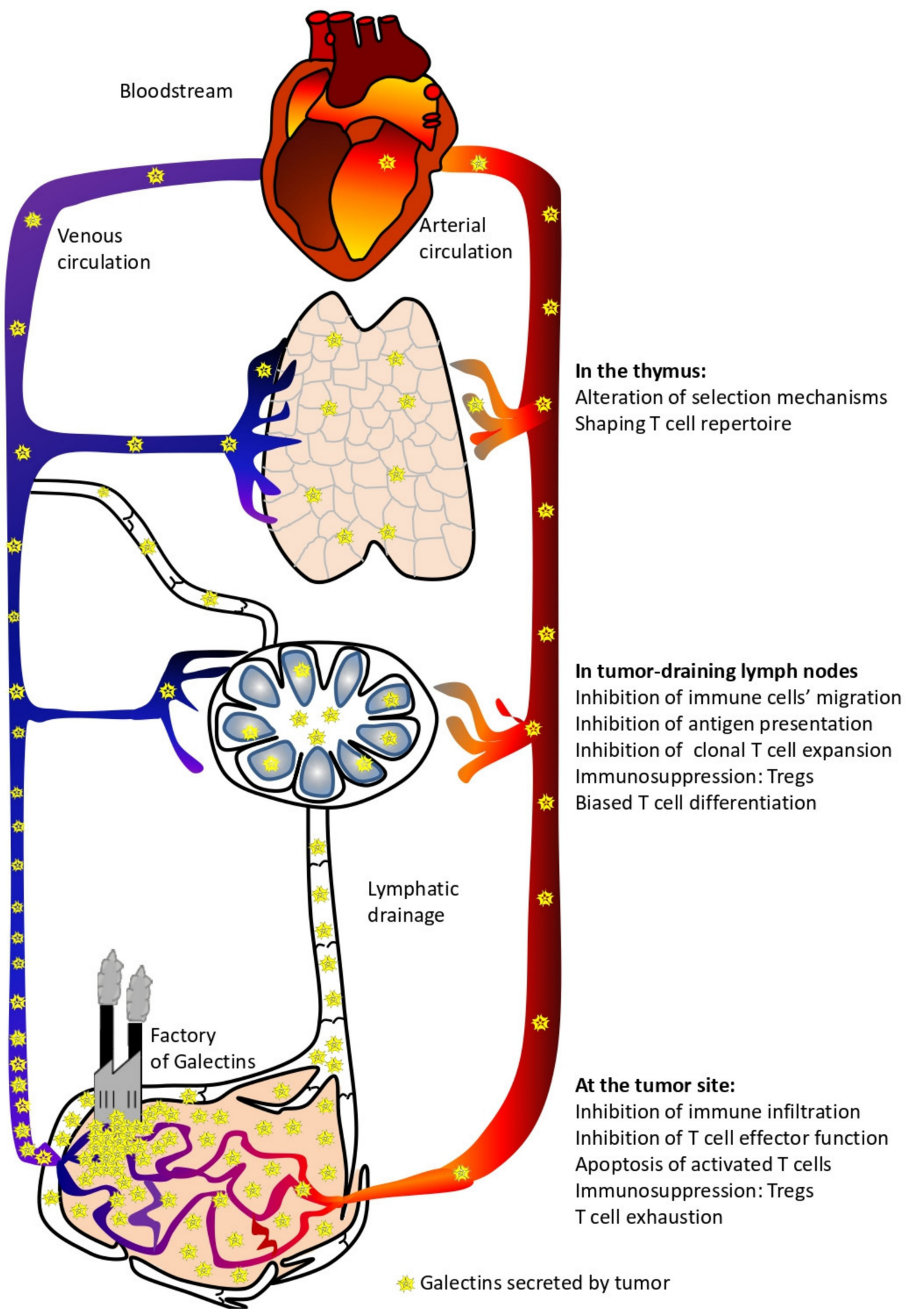

Figure 1. Local and systemic effects of circulating tumor-derived galectins.

\subsection{Do Circulating Tumor-Derived Galectins Have Any Impact on Nä̈ve T Cell Production?}

From the approximately $2-7 \times 10^{7}$ naïve T cells produced in the thymus every day during adulthood [122,123], very few cells are specific against self-components due to the relative efficiency of the negative selection process [124]. However, if the cancer immunosurveillance theory is correct (which is supported by the low frequency of tumor occurrence throughout our lives) [125], lymphocytes with anti-self-reactivity, available in 
the periphery in healthy individuals, may be enough to kill cells early after their malignant transformation. However, this optimistic scenario changes radically when transformed cells escape to immune pressure and become less immunogenic. During this tumor development phase, severe impairment of intrathymic $\mathrm{T}$ cell differentiation/maturation has been reported, leading to a paralysis of cellular anti-tumor immunity [126-130]. Simultaneously, tumors produce large amounts of galectins (mainly galectins $-1,-3,-7,-8$, and -9 ). As already stated, increased levels of galectins in patients' sera have been reported for several cancer types [27-38]. In such conditions of abundant production and secretion, galectins circulate through biological fluids and reach the thymus. Indeed, it was demonstrated that under stress conditions, high levels of circulating galectin-1 are associated with increased numbers of galectin-1-positive cells in the thymus medulla. This effect is not genetically mediated since no upregulation of galectin-1 mRNA was observed in thymic cells [131,132]. In this context, do galectins produced by the multiple cell types within a tumor impact $\mathrm{T}$ cell production and education in the thymus?

Since thymic education involves a high rate of cell death [133], galectins' role in the regulation of thymic apoptosis awakes a particular interest. There exists information about the thymocyte pro-apoptotic role for most of the galectins produced by tumors (galectins-1, $-3,-8$, and -9 ).

Physiologically, galectin-1 is detected in thymic epithelial, endothelial, and dendritic cells, as well as macrophages [134,135]. From a functional point of view, galectin- 1 induces thymocyte apoptosis [136]. This initial result was extensively confirmed under different experimental conditions, allowing a better understanding of this biological phenomenon. The highly proliferating immature $\mathrm{CD} 4+\mathrm{CD} 8+$ double-positive thymocytes are the primary targets for galectin-1-induced cell death $[136,137]$. This FAS-independent apoptosis relies on a thymocyte permissive glycophenotype and involves the lectin interaction with CD7, CD43, and CD45 receptors $[55,56,58,59,138]$. Pro-apoptotic properties of galectin-1 on thymocytes have usually been evaluated in vitro using a soluble recombinant protein; only a few studies have used a more relevant biological context, demonstrating that galectin1 produced in situ by cells have such a pro-apoptotic effect on $\mathrm{T}$ cell lines $[46,139,140]$. Furthermore, no report has addressed this issue using primary $\mathrm{T}$ cells. This point is crucial since galectin-1 is an inactive monomer that becomes a biologically active homodimer through non-covalent bonds with a $\mathrm{Kd}$ around $7 \mu \mathrm{M}$ (equivalent to a concentration of $98 \mu \mathrm{g} / \mathrm{mL}$ ) [141,142]. Based on this low homodimerization constant, high amounts of the protein are needed to reach the critical concentration required for the active dimer formation. Even if a genetically engineered dimeric galectin-1 reduces tenfold the concentrations of the protein to achieve a biologically active form [143], the required concentration of the lectin remains high.

Galectin-3 was also detected in epithelial and phagocytic cells in the medulla and, to a lesser extent, in the cortical regions of the thymus [74,144]. It is important to remark that galectin-3 has opposite effects on cells depending on its extracellular or intracellular localization $[145,146]$. Similar to galectin-1, extracellular galectin-3 induces thymocyte apoptosis. However, galectin-3 preferentially targets a different cell subpopulation (CD4CD8- double-negative thymocytes) [74]. Furthermore, and although both galectin- 1 and galectin-3 induced apoptosis are carbohydrate-dependent, galectin-3-mediated effects are different in several aspects: galectin-3 uses distinct sets of glyco-receptors (does not require CD7) and involves different molecular mechanisms [74]. Further, galectin-3 is more potent at inducing cell apoptosis when compared to galectin-1. However, galectin3 's pro-apoptotic effects still require concentrations in the order of $\mu \mathrm{M}$. In addition, this pro-apoptotic effect of extracellular galectin-3 opposes the anti-apoptotic function of intracellular galectin-3 [147]. Additionally, intracellular galectin-3 blocks galectin-1-mediated apoptosis [138], implying that both galectin members are closely interrelated in the control of thymocyte apoptosis.

Galectin-9 induces carbohydrate-dependent cell death in thymocytes [138]. Galectin-9 is detected in epithelial cells throughout the thymus, but it is more abundantly found in 
the medulla compared to the cortical regions of the thymus [138]. Again, galectin-9 has its particularities when compared against other galectins. Galectin-9 induces the cell death of all thymic subpopulations [138]; other galectins show more population-specific effects. Thymocytes' apoptosis induced by galectin-9 involves receptors that are different from those used by galectins- 1 and -3 : while at present the relevant receptors remain unknown, CD44 could be a potential candidate since it has been demonstrated to bind galectin-9 in peripheral T cells $[112,113]$. At a mechanistic level, galectin-9-mediated apoptosis involves, at least partially, a Bcl-2-mediated pathway [138]. In addition, galectin-9 is more potent than the other galectins at inducing $\mathrm{T}$ cell death $(<1 \mu \mathrm{M}$ is effective) $[138,148]$.

Galectin- 8 is also found in the thymus but, in contrast to galectins-1, -3 , and -9 , it is not detected in thymic epithelial cells [149]. This galectin induces apoptosis of CD4+ CD8+ double-positive thymocytes through a mechanism that, at least partially, involves activation of the caspase-mediated pathway. In this in vitro study, concentrations of galectin- 8 ranging from 0.5 to $2 \mu \mathrm{M}$ were effective at inducing apoptosis [149].

Former evidence supports galectins acting as pro-apoptotic factors for thymocytes when produced in situ under physiological situations. Thus, galectins produced abundantly by tumors could shape the repertoire of newly generated T lymphocytes. As previously stated, galectins can circulate through biological fluids and reach the thymus. Although it is difficult to transfer in vitro concentrations to tissue levels, comparing the concentrations of circulating galectins in sera (in the order of $\mathrm{ng} / \mathrm{mL}$, as found in the 55 reports currently available for different cancers; some were cited before) with the concentrations of galectins required to trigger thymocyte apoptosis (in the order of $\mu \mathrm{g} / \mathrm{mL}$ ), the galectin concentrations reaching the thymus are likely insufficient to induce the thymocytes' cell death. The only way tumor-derived galectins could induce thymocyte apoptosis would be by trapping these lectins, which would allow reaching the required galectin concentrations locally. To date, this phenomenon has not been described. Otherwise, if $\mu \mathrm{M}$ concentrations are reached in biological fluids, galectins may induce dangerous side effects, such as the aggregation of different types of cells $[143,150]$ and potential systemic immunosuppression. Taking these arguments together, it seems unlikely that tumor-derived, circulating galectins can induce cell apoptosis in the thymus.

Apart from apoptosis, other biological properties, such as cell-to-cell interactions, can be regulated by galectins in the thymus [151]. For instance, galectin-3 was described as a factor promoting thymocytes' release from thymic epithelial cells. Therefore this protein is a de-adhesive factor [144]. Conversely, a pro-adhesive role has been ascribed to galectin-1 through its interaction with several proteins of the extracellular matrix [134]. Thymic galectin- 9 also acts as an adhesive molecule since it induces thymocyte homotypic aggregation [150]. Once again, all these biological aspects of galectins have essentially been addressed in vitro and require the use of high concentrations of recombinant proteins. It is, therefore, unlikely that any cell attachment-related modulation in the thymus can be ascribed to circulating and tumor-derived galectins.

Despite former arguments against the role of circulating and tumor-derived galectins in controlling thymic apoptosis and cell attachment-related functions, the evaluation of murine galectin-deficient models highlight that these proteins play essential roles in the control of thymocyte development. Indeed, while data identify endogenous galectin-1 as being not essential for thymocyte development (unaffected general thymic subpopulation numbers and percentages), this protein shapes the $\mathrm{T}$ cell repertoire acting as a selective modifier of positive and negative selection processes [152]. Indeed, physiological thymic galectin-1 opposes positive selection while it promotes negative selection of conventional $\mathrm{CD} 8+\mathrm{T}$ cells. This conclusion was further confirmed by the use of a galectin-1-specific inhibitor in fetal thymic organ cultures; such treatment enhanced CD8+ T cell development [152]. The failures in thymic selection processes observed in galectin-1-deficient mice could explain (at least partially) some of the peripheral autoimmune phenomena spontaneously observed in these mice [153,154]. 
Endogenous galectin-3 is another member with an important modulation role in thymocyte development. Indeed, thymocyte subpopulations in galectin-3-deficient mice show a reduction in thymus cellularity, which is due to reduced in vivo proliferation and increased apoptosis of thymocytes [155]. Interestingly, although exogenous galectin-3 induces $\mathrm{T}$ cell apoptosis, the absence of endogenous galectin- 3 also induces thymocyte apoptosis. This last point was demonstrated by genetic ablation and confirmed by specific inhibition experiments. Therefore, it is evident that optimal production of Tymphocytes requires physiological levels of galectin-3.

Up to mid-2021, no report indicates alterations in the thymic selection processes due to gene invalidation of galectins-7, -8 , and -9 . Nevertheless, it is interesting to note that galectin-7 is detected in Hassal corpuscules located in the medulla of the thymus [156]. While a functional significance remains unclear, this observation indicates a potential role of galectin-7 in thymic regulation. Altogether, data on galectins- 1 and -3 supports that serum concentrations of galectins detected in cancer patients could modify the repertoire of T lymphocytes exported from the thymus to the periphery. Mechanisms by which this happens remain to be determined and more studies on the role of other galectins are necessary. Here, it is also important to note that, in addition to their lectin functions that require high concentrations to induce glycan-lectin lattices, galectins also act as regulators of gene expression, transcript maturation, and intracellular signaling [4,68,83,91,93,94,96,157-161]. Most of these later functions are glycan-independent and therefore require lower galectin levels [161]. The galectin concentrations detected in the circulation of cancer patients are consistent with these non-lectin functions. Therefore, galectins can act like soluble factors controlling the thymocyte educative process through effects on the thymocytes themselves or, indirectly, via effects on the stromal cells that participate in their education. Additional basic research can shed some light on these concerns.

\subsection{T Lymphocyte Regulation by Galectins at the Periphery}

In humans, the peripheral $\mathrm{T}$ cell pool is constituted by approximately $4 \times 10^{11}$ naïve $\mathrm{T}$ lymphocytes [123]. In general, analysis of the murine peripheral $\mathrm{T}$ cell repertoire has demonstrated that each naïve clonotype is made up of few cells [162]. Similar low frequencies for each $\mathrm{T}$ clonotype have been found in humans [163]. More stringent restrictions apply to the anti-tumor-specific $\mathrm{T}$ cell repertoire since potent central selection processes only allow the exit of low avidity clonotypes against self-epitopes [164]. On the other hand, the frequency of anti-tumor $T$ cells is increased through the clonotypes reactive against the neoepitopes, which arise as a consequence of tumor genetic instability; these clonotypes are not eliminated by central tolerance $[165,166]$. In general, basic studies have reported variable, low frequencies of pre-existing anti-tumor T lymphocytes in healthy individuals [167-169]. These low numbers of cells constitute the available army to recognize and eliminate transformed cells. In cancer patients, the said T cells expand and gain cytotoxic function in a tumor-dependent manner since each of these cancers differs in their mutational ratio, in their immunogenicity [170], and use of evasion pathways. Despite these considerations, the low number of specific anti-tumor $\mathrm{T}$ cells represents a real challenge for immuno-oncology. This fact implies that the expansion and gain of function of the few tumor-specific $\mathrm{T}$ cells must be as efficient as possible, at the risk of losing these effector cells. Hence, understanding the tumoral strategies leading to lymphocyte de-functionalization is essential to counteract them during cancer immunotherapies.

To assess the role of tumor-derived galectins on the function of immune cells in the periphery, we will focus on two anatomical locations where tumors have a direct and significant influence: the draining lymph nodes and the tumor itself. It does not imply that circulating galectins (produced by tumors) can influence cellular functions in other anatomical locations; these are beyond the scope of this review. 


\subsubsection{Galectins' Functions in Tumor-Draining Lymph Nodes}

The first stages of lymphocyte activation occur in the draining node. There, a specific clonal expansion process is carried out [171]. Tumor-derived galectins can reach this anatomical location via blood and lymphatic vessels as soluble proteins, transported by cells or contained in exoparticles [172]. Once in lymph nodes, galectins impact on the early lymphocyte activation process. As mentioned above, there is abundant literature about the pro-apoptotic functions on recently activated Tlymphocytes for the 5 galectins evaluated in this review. However, the concentrations of galectins found in blood and lymphatic fluids are unlikely to induce the glycolattice formation required for the said function. As previously discussed in the thymus section, it is therefore unlikely that the tumor-derived galectins in circulation modulate lymphocyte function in lymph nodes through their lectin properties. In contrast, other lymphocyte functions may be finely regulated by circulating tumor-derived galectins.

The emergence of a tumor is associated with a complete reorganization of the local tissue architecture, with major impacts on blood and lymphatic vessels. Indeed, circulating galectin-1 can be taken up by and control the functional properties of endothelial cells [20]. It is worth noting that galectin-1 expressed by endothelial cells plays a major regulatory role in the homing of naïve lymphocytes towards the lymph nodes [135,173,174]. Indeed, lymphocyte recruitment is significantly reduced in vitro. This phenomenon happens when endothelial cells are treated with recombinant galectin- 1 at nM concentrations [173] or when endothelial cells upregulate galectin- 1 following their incubation with tumor cellconditioned media [135]. The latter is an example that mimics how tumor products can alter physiology, even at a distance. It is important to note that these $\mathrm{nM}$ concentrations (around $14 \mathrm{ng} / \mathrm{mL}$ ) are compatible with the levels of galectins detected in biological fluids. More importantly, lymphocyte homing is significantly increased in galectin-1 deficient compared to wild-type mice [173]. This biological effect occurs independently of cell death [135] and both in physiological and inflammatory conditions [173]. Thus, tumorderived galectin- 1 decreases the influx of naïve $T$ cells into the draining lymph nodes, accounting for a reduction in $\mathrm{T}$ cell activation and clonal expansion.

Despite regulation of cell migration through the blood endothelium, galectin-1 also plays a significant role in the formation of new lymphatic vessels. Indeed, genome-wide functional analysis revealed that galectin-1 is one of the major regulators of lymphatic endothelial cell function [175]. Therefore, this protein has a major impact on how tumorderived antigens and antigen-presenting cells arrived at the draining lymph node through lymphatic vessels. Furthermore, galectin- 1 inhibits the migration of immunogenic dendritic cells through the extracellular matrix and across lymphatic endothelial cells [176].

Galectin-1 compromises cell migration, and the T lymphocytes that effectively reach the draining lymph node are poorly activated if this lectin is present in the local media. Indeed, galectin-1 imparts a regulatory program in dendritic cells, resulting in lower lymphocyte priming $[177,178]$. However, regulation of the dendritic cell properties by galectin-1 does not exclusively depend on the extracellular concentrations of this lectin since endogenous galectin-1 also controls dendritic cell immunogenic potential [177,179,180]. Altogether, galectin-1 plays an essential role in controlling the initial steps of antigenspecific lymphocyte activation. Indeed, lymphocytes from the draining lymph nodes of galectin-1-silenced tumors are more prone to proliferation and produce higher levels of IL-2 and IFN $\gamma[181,182]$. The tumor origin of galectin- 1 that causes alterations in antigen presentation is further supported by the fact that these biological effects are observed in the draining but not in other tumor-distant lymph nodes [181].

However, comprehension of the scenario in its full complexity requires additional clues. Indeed, the use of antigen-presenting cell-free systems demonstrated that galectin-1 modulates TCR-mediated signaling $[137,183]$. Accordingly, galectin-1 directly affects T cells during the early steps of activation, which are not only dependent on accessory cells. Altogether, tumor-derived galectin-1 promotes lymphocyte differentiation towards Th profiles that are inefficient to eliminate transformed cells [28,52,184-186]. In this respect, 
endogenous lymphocyte galectin-1 can control cell function at the level of gene expression regulation (reviewed in [4]). Indeed, endogenous galectin-1 in lymphocytes controls their expansion [187] and differentiation [188,189] in a variety of experimental models. In cancer, our group demonstrated that the inactivation of endogenous galectin- 1 in lymphocytes reverses tumor immunosuppression [190].

Finally, tumor-derived galectins participate in the recruitment of cells with regulatory function in lymph nodes and thus have a major impact on the clonal expansion of antitumor $\mathrm{T}$ lymphocytes. Indeed, galectin-1 silencing in tumors reduces the frequency and the suppressive function of CD4+ CD25+ FOXP3+ regulatory T cells (Tregs) in draining lymph nodes [191]. Furthermore, Tregs require galectin-1 to be fully suppressive; galectin-1 neutralization reverses immunosuppression by Tregs [62,192]. Galectin-1 plays also an important role in the differentiation and suppressive function of CD122+ PD-1+ CD8+ Tregs [193]. In addition, this galectin also attracts other regulatory cells, such as M2 macrophages and myeloid-derived suppressor cells, to the tumor-draining lymph nodes, as it does towards the tumors themselves [194-198].

Galectin-3 is another member of this lectin family with a significant impact on the anti-tumor lymphocyte activation occurring in the draining lymph nodes. Our laboratory recently demonstrated that tumor galectin-3 is a potent negative checkpoint that suppresses lymphocyte proliferation in a prostate cancer microenvironment [199]. Furthermore, galectin-3 downregulation is a pre-requisite for optimal lymphocyte activation when a dendritic cell-based vaccine is used in prostate cancer. In such a case, long-term protective immunity is achieved [199]. Additional evidence suggests that galectin-3 could also act as a negative immune checkpoint in other types of cancers $[72,75,79,200]$.

Among the molecular mechanisms accounting for the powerful lymphocyte inhibitory effect of galectin- 3 in cancers, this protein modulates the interactions between $\mathrm{T}$ cells and antigen-presenting cells [85]. First, galectin-3 deficient immature dendritic cells have defective motility properties [201]. Consequently, by controlling the dendritic cell migration from the peripheral tissues (including tumors) to the draining lymph nodes, galectin-3 has a direct role in eliciting anti-tumor immune responses. Furthermore, this particular galectin also contributes to dendritic cell homeostasis since it was observed that galectin-3deficient mice have increased numbers of plasmacytoid dendritic cells [79]. Interestingly, plasmacytoid dendritic cells are superior to conventional ones in activating anti-tumor CD8+ T lymphocytes [79]. Finally, information obtained from experimental models of infection has demonstrated the critical function of galectin-3 on the adaptive immune responses triggered by dendritic cells [202-204]. Altogether, these data seem to indicate galectin-3 plays a role at the initial steps of tumor antigen presentation.

Galectin-3 also has a direct effect on T lymphocytes. First, the galectin-3 expression on tumor cells negatively impacts the T lymphocyte numbers in lymph nodes [199]. This effect can be explained through the regulation at the initial steps of the lymphocyte activation process. Indeed, galectin-3 modulates the immunological synapse formation, restricting TCR movements, potentiating TCR downregulation, suppressing early TCR signaling pathways, and controlling cytokine production $[73,76,85,205]$. Extracellular galectin-3 accomplishes these biological effects via interactions with membrane glyco-receptors as well as by reducing the availability of soluble proteins (in particular cytokines like IL-2, IFN $\gamma$, and IL-12) [72]. These functions are glycan-dependent. Subject to the surrounding microenvironment, endogenous galectin- 3 is upregulated in T cells early upon activation and skews their differentiation program. Indeed, galectin-3 deficiency promotes immune responses that favor effectors and effector memory $\mathrm{T}$ cells to the detriment of the generation of central memory T cells $[85,206]$. Furthermore, it was described that the survival of recently activated $\mathrm{T}$ cells might be affected by galectin-3. Indeed, in vitro studies have demonstrated that extracellular galectin-3 induces apoptosis in human $\mathrm{T}$ cells by directly binding the glycoprotein receptors CD45 and CD71 [74]. However, similarly to what was discussed on galectin-1, it is unlikely that tumor-derived circulating galectin-3 reaches the concentrations required to reveal its pro-apoptotic properties in the tumor-draining lymph 
nodes in cancer patients. It is also important to note that during activation, lymphocytes upregulate intracellular galectin-3 [206,207], which protects T cells from apoptosis [147,206]. Thus, the role of galectin-3 on the survival of newly activated lymphocytes in the lymph nodes is complex, and its real pathologic relevance remains controversial. On the other hand, the expression of galectin-3 by the stroma is required to recruit CD4+ CD25+ FOXP3+ Tregs towards immune organs in tumor-harboring mice [200]. Considering all these arguments, tumor-derived galectin-3 may substantially impact $\mathrm{T}$ cell activation, expansion, and polarization of the immune responses elicited in tumor-draining lymph nodes. This concept is relevant not only to the design of in vivo vaccine strategies [199] but also to adoptive $T$ cell transfer of ex vivo-expanded tumor-reactive T cells [208].

Currently, few studies have evaluated the effect of galectin- 8 in the process of antitumor immune activation. First, galectin- 8 crosstalk among the VEFG-C, podoplanin, and integrin pathways plays a key role in lymphangiogenesis [209]. Indeed, podoplaninexpressing macrophages promote lymphangiogenesis in breast cancer via interaction with galectin-8 on lymphatic endothelial cells [210]. Some additional information can be drawn from other (non-tumoral) experimental models. Indeed, galectin-8 promotes all steps of antigen presentation from antigen binding, internalization, processing [211], and maturation of dendritic cells $[212,213]$. Studies with galectin- 8 deficient antigen-presenting cells confirmed the relevance of such functions in pathophysiology [212]. This experimental model seems more relevant compared to artificial in vitro use of high concentrations of recombinant galectin-8. Aside from the antigen-presenting cell-dependent naïve CD4+ T cell co-stimulation that occurs with low galectin- 8 concentrations, it was demonstrated that higher concentrations of galectin-8 induce antigen-independent proliferation of CD4+ T cells [214]. However, higher concentrations seem unlikely to be reached in tumor-draining lymph nodes, while low ones could play a role in controlling tumor antigen presentation in those immune organs.

Finally, recombinant galectin-8 increases differentiation of CTLA-4+ IL-10+ CD103+ Tregs through activation of TGF- $\beta$ and sustained-IL-2 receptor signaling [215]. Tumors could use this strategy to block immunity in draining lymph nodes. In summary, little is known about the biological functions of galectin-8 in lymph nodes during cancer. Compilation of existing data indicates that secretion of this protein would not generate a strong selective advantage for tumors. On the contrary, galectin-8-based strategies could potentiate anti-tumor immunity since this lectin can lower the TCR activation threshold [216].

While the anti-tumor effect of galectin-9 was demonstrated in several experimental models [111,217-219], other strategies demonstrated galectin-9 has apparent diametrical opposite roles in immune regulation [220-224]. Possible explanations for these dichotomic observations range from the doses of galectin-9 used in the experiments, alternative regulations in different cell types, different receptors this lectin binds, different galectin-9 topographic localization in these cells (interaction with glyco-receptors exposed at the extracellular space contrasting to intracellular effects), different phases of the disease, and the activation of different signaling pathways in inflammatory versus tolerogenic microenvironments.

Interestingly, it was reported that low galectin-9 doses serve as an activation signal for resting $\mathrm{T}$ cells in the absence of any antigen stimulation. Indeed, exogenous galectin9 initially causes the death of some naïve cells, but it induces robust proliferation of the surviving T cells [225]. Furthermore, exogenous galectin-9 increases early calcium mobilization and sensitizes T cells for higher IL-2 and IFN $\gamma$ production $[226,227]$. These effects are antigen-independent and result in important changes in T cell phenotypes [225]. Therefore, tumor secreted galectin- 9 can shape the available $\mathrm{T}$ cell repertoire by a direct action on resting $\mathrm{T}$ cells without any antigen stimulation.

During activation of anti-tumor-specific responses, exogenous galectin-9 modulates antigen presentation, promoting the differentiation of plasmacytoid dendritic-like cells [217], dendritic cell maturation, and a Th1 polarizing microenvironment $[111,228]$. Furthermore, the exogenous levels of galectin-9 serve as a potent regulator of cytokine production by $\mathrm{T}$ cells. This effect depends on the interactions with glycans but does not involve the T cell immunoglobulin 
and mucin domain-containing protein 3 (Tim-3) receptor [227]; this last being one of the main receptors described for galectin-9. On the other hand, the intrinsic expression of galectin-9 in $\mathrm{T}$ cells regulates early events of T cell activation. Indeed, galectin-9-deficient $\mathrm{T}$ cells show impaired proliferation, which cannot be recovered by exogenously added galectin-9 [229]. It was demonstrated that this galectin is recruited to the immune synapse upon T cell activation, contributing to proximal TCR signaling [229]. Altogether, these results indicate a positive regulation of $\mathrm{T}$ cell activation and expansion by galectin-9.

Galectin-9 also promotes immune regulation. During the initial events of naïve CD4+ $\mathrm{T}$ cell activation and clonal expansion occurring in lymph nodes, some T helper cells secrete galectin-9 with the concomitant production of IL-10 and TGF $\beta[230,231]$. In this cytokine scenario, conventional $\mathrm{T}$ cells acquire regulatory functions (so-called induced regulatory T cells, iTreg). Galectin- 9 is, therefore, a paracrine and autocrine factor that enhances the expansion and suppressive phenotype of iTregs [113]. Indeed, galectin-9 interacts with the CD44-TGF- $\beta$ RI complex to stabilize the expression of FOXP3, the master transcription factor of conventional Tregs. Besides controlling CD4+ CD25+ FOXP3+ Tregs function, galectin-9 also clusters the 4-1BB receptors, promoting in vivo accumulation of CD8+ Tregs, an alternative suppressive pathway activated during inflammation [115]. Furthermore, galectin- 9 binds the V-domain Ig suppressor of $\mathrm{T}$ cell activation protein (VISTA). This interaction induces $\mathrm{T}$ cells to acquire a dysfunctional phenotype [232]. Galectin-9 also promotes CD11b+ Ly-6G+ myeloid-derived suppressor cells, an additional point of regulation of $\mathrm{T}$ cells expansion. This effect on myeloid suppressor cells requires the interaction of galectin-9 with the Tim-3 receptor [233]. However, several inducible receptors in T cells are involved in galectin-9-mediated immunoregulation: Tim-3 [234], CD44 [113], DR3 [117], 4-1BB [115], CD40 [116], and the protein disulfide isomerase [118].

In addition, galectin-9 is also described as an apoptosis inducer of activated T cells (discussed in depth in the next chapter). However, the concentrations of lectin required to induce cell death (in the order of $\mathrm{nM}$ ) are unlikely to be reached in the tumor-draining lymph nodes, precluding any pro-apoptotic role of tumor-derived galectin- 9 at this anatomical localization. Finally, it is important to note that galectin-9 interventions in cancer may take some considerations on kinetics and receptor expressions into account. For instance, TCR downregulation is a well-known phenomenon occurring early during $\mathrm{T}$ cell activation in lymph nodes [235]. Considering that some of the described functions for galectin-9 require the integrity of the TCR/CD3 signaling pathway (such as calcium mobilization) [226], these functions of galectin-9 may not be relevant in recently activated lymphocytes in tumor-draining lymph nodes.

\subsubsection{Galectin Functions inside the Tumor}

Tumor $\mathrm{T}$ cell infiltration and effector functions are important biomarkers for predicting better clinical outcomes [236-238]. Several preclinical models have evaluated the impact of galectins-1, $-3,-7,-8$, and -9 produced by tumors in controlling $\mathrm{T}$ cell behavior. It is important to note that tumors are made up of different types of cells, including transformed cells and non-transformed stroma (fibroblasts, macrophages, endothelial and immune cells, among others). All of these cells contribute to the tumor production of galectins.

In the case of galectin-1, experimental evidence demonstrated that galectin-1 from the tumor, and not from the host, plays a fundamental role in contributing to tumor growth and distant metastasis $[194,239,240]$. Consequently, experiences in which galectin-1 was inhibited in tumor cells have shown that this lectin serves as a potent pro-tumor agent $[174,181,182,194,239,240]$. The mechanisms by which this regulation happens remain a matter of discussion. However, it is incontestable that galectin-1 pro-tumor effects require the active participation of the immune system. Indeed, tumors expressing or not galectin-1 grow indistinctly in immunodeficient mice $[52,181,239,241,242]$, clearly indicating that the immune system is the major target of tumor-galectin-1. Furthermore, immune cell depletion experiences indicate that CD4 and CD8 T lymphocytes are involved in the effects of galectin-1 [181,194]. This concept is also supported by the use of CD8 T lymphocyte- 
deficient mice [174]. Additionally, cells of innate immunity could also play a direct or indirect role in these biological phenomena $[194,197,243]$.

What are the mechanisms by which tumor-derived galectins accomplish immune deactivation? A hypothesis raised by Van der Brûle in 2001 supports the concept of galectin-1 serving as a tumor-protective shield since this lectin induces the death of effector cells reaching the tumor [39]. Indeed, a seminal article published in 1995 was the first to demonstrate that galectin-1 induces apoptosis of T lymphocytes [139]. While this pioneering result showed that all $\mathrm{T}$ lymphocytes bind galectin-1 [139], further studies have revealed that this protein has the opposite biological effects in naïve versus activated $\mathrm{T}$ cells. While galectin-1 (at low concentrations) promotes survival of resting naïve T cells [244], activated Th1 effector cells have a permissive glycophenotype that allows galectin- 1 to induce their apoptosis $[139,185,245]$. The latter include effector cells that should migrate toward tumors to accomplish their cytotoxic function.

However, the pro-apoptotic effects of galectin- 1 on activated $T$ cells remain controversial in several aspects. First, regarding in vitro methodological issues related to the use of reducing agents in galectin-1 preparations, the said reagents per se can induce apoptosis in $T$ cells [246]. Therefore, in vitro studies that use recombinant galectin- 1 obtained in such conditions should be analyzed with caution. Furthermore, the evaluation of the entire in vivo picture highlights that even if tumors produce abundant galectin-1, their microenvironment is highly oxidative (high levels of oxygen and nitrogen derived-species resulting from its metabolism) [247]. The oxidative microenvironment together with the requirement of high protein concentrations for homodimerization may make it difficult for galectin-1 to reach optimal conditions to induce apoptosis of the infiltrating effector lymphocytes. Therefore, this tumor pro-apoptotic function seems to require particular conditions: galectin-1 reaching locally high concentrations and protected from the oxidative microenvironment. In this sense, after secretion, galectin-1 can remain within the cell membrane and be associated with components of the extracellular matrix. At this localization, tumor galectin- 1 is more effective in its pro-apoptotic activity [46]. This phenomenon is crucial for preserving its lectin activity since the binding of galectin- 1 to sugar residues on membrane proteins prevents it from being oxidized by the cell environment [141,248]. In addition, galectins can also compartmentalize in particular cell membrane structures (e.g., lipid rafts where some galectins have been detected $[201,249])$ and therefore be protected from the extracellular redox damage [118]. These observations indicate that tumors can induce topographic sites of intimate cell-to-cell contacts that privilege galectin- 1 expression in an active and $\mathrm{T}$ cell pro-apoptotic form. This concept is supported by very few reports that have evaluated the in vivo tumor lymphocyte pro-apoptotic effect [239] or by using relevant co-culture systems [186,250-252]. This information also indicates important differences between the galectin-1 effects in the tumor and other lymphoid organs. Indeed, at the tumor site, galectin-1 may exert its lymphocyte pro-apoptotic effect only if the microenvironment allows a close contact between lymphocytes and tumor cells. In contrast, the galectins produced by the tumor could not be considered as soluble factors with T cell pro-apoptotic functions in other lymphoid organs (as developed in previous chapters).

Nevertheless, other experimental models do not support the in vivo lymphocyte proapoptotic effects of tumor galectin-1 $[174,253]$. Therefore, alternative mechanisms should also be considered. While the growth of wild-type tumor cells is hampered in galectin-1deficient mice, the same tumor cells are tumorigenic in wild-type mice $[20,190,241,243]$. This observation supports the relevance of the tumor-associated stroma in galectin-1 mediated effects. On the one hand, galectin- 1 is a potent pro-angiogenic factor $[20,25,51,52,254,255]$. Besides providing tumors with nutrients/oxygen/hormones, etc., the formation of new blood vessels should facilitate the arrival of lymphocytes and promotes tumor infiltration (if the correct adhesion molecules are expressed). This is not the case in several models; the expression of galectin-1 in stromal endothelial cells induces less lymphocytic infiltration $[135,256]$. Furthermore, the galectin- 1 produced by tumors is taken up by endothelial cells, activates these cells, and promotes neovascularization $[20,257,258]$, but inhibits lymphocyte 
migration through the endothelium and the extracellular matrix $[135,173,174]$. The net result is lower intra-tumoral lymphocyte infiltration $[52,182,197,253,256]$. In this case, the concentrations of galectin- 1 detected in pathophysiological situations (around $\mathrm{nM}$ ) are capable of reducing lymphocyte attachment and adhesion to activated endothelium $[173,174]$. Furthermore, it was also nicely demonstrated that tumor-derived galectin-1 upregulates PD-L1 and galectin-9 in endothelial cells. This molecular pathway is responsible for the inhibition of lymphocyte migration towards tumors, reversing the immune checkpoint resistance observed in some cancer patients [174]. Thus, a concept that deserves increasing attention positions galectin- 1 secreted by tumors as a paracrine molecule acting on the stroma to create a microenvironment permissive for tumor growth. In this context, our group demonstrated that tumors significantly impact the intracellular levels of galectin-1 in T lymphocytes. This phenomenon is a powerful way by which tumors control $\mathrm{T}$ cell proliferation and effector properties. Indeed, lymphocytes with higher levels of galectin-1 show lower cytotoxic effector capacity within a tumor contexture [190]. Experimental data also support that the intrinsic galectin-1 in T lymphocytes have major regulatory functions in other models of $\mathrm{T}$ cell immunity: infections, allergic contact dermatitis, and autoimmunity $[188,189,259,260]$. Aside from direct regulation of T cell function, galectin-1 may also control lymphocyte behavior through the participation of other cells. Indeed, several types of tumors are characterized by significant Treg cell infiltrates (reviewed in [261]). This observation indicates that suppression of $\mathrm{T}$ cell expansion does not only occur at the draining lymph nodes. Tumors can be considered tertiary immune organs where $\mathrm{T}$ cell proliferation is still possible and thus must be suppressed. In this context, the galectin-1 produced by tumors may control the function of Tregs in a paracrine manner [191,192,262]. Indeed, blockade of exposed galectin-1 in Tregs reduced their suppressive properties [192]. This regulatory effect of galectin- 1 is such a potent mechanism that it can also control immunity at distant metastatic sites [191]. Apart from Tregs, other immune-suppressive cells are also modulated by tumor-derived galectin-1. Indeed, intra-tumor accumulation of myeloid cells depends on tumor-derived galectin-1 [194,197,263], a phenomenon intimately related to the microbiota through the participation of $\gamma \delta$ T cells [243]. This last observation evidences the complex cellular network that coordinately regulates immune responses against tumors, some occurring at a distance from the tumor site.

Tumor galectin-3 is an additional potent regulator of lymphocyte effector properties at the tumor site $[72,199]$. First, $\mathrm{T}$ cell recruitment towards the tumor requires an IFN $\gamma$-induced CXCL9/10 gradient of chemokines. It has been demonstrated that IFN $\gamma$ entrapment by galectin-3 in the tumor extracellular matrix prevents the creation of such a chemokine gradient required to attract $\mathrm{T}$ cells towards the tumor [72]. The relevance of this phenomenon was also confirmed after demonstrating that galectin-3 interacts with glycans of IFN $\gamma$-R2, therefore interfering with Janus-activated tyrosine kinase/signal transducer and activator of transcription (JAK/STAT) activation (an essential signaling pathway in responding T cells) [264]. Besides regulating $\mathrm{T}$ cell migration, galectin-3 also controls effector functions. Indeed, galectin-3 silenced tumors elicit lymphocytes with increased degranulation capability and specific anti-tumor cytotoxicity [199]. Mechanistically, it was demonstrated that galectin-3 decreases lymphocyte effector functions through downregulation of the TCR, thus transforming $\mathrm{T}$ infiltrating lymphocytes (TILs) into dysfunctional cells [75]. These defective rearrangements at the T cell synapse induced by galectin- 3 are responsible for the failure of CD8+ TILs to attach to their specific targets and to secrete killing cytokines (even while these cells produce normal amounts of cytokines) [76]. These galectin-3-mediated effects are local (inside the tumor) since the functional unresponsiveness of TILs contrasts with the functional properties of blood T cells $[75,265]$. The dysfunctional state of intra-tumor lymphocytes induced by galectin-3 is further supported by their expression of terminal $\mathrm{T}$ cell deactivation/exhaustion markers [266]. Indeed, the CD8+ TILs that bind galectin-3 in the tumor microenvironment co-express LAG-3 and PD-1 [79]. This study demonstrated the central role LAG-3 plays in galectin-3-mediated suppression of lymphocyte anti-tumor effector function [79]. All these arguments support 
the significant role of galectin-3 in reducing tumor infiltration and the killing function of activated $\mathrm{T}$ lymphocytes.

In addition, and since galectin-3 was described as pro-apoptotic for activated lymphocytes $[74,145,147,267]$, the same considerations previously stated for galectin- 1 apply for galectin-3. Indeed, galectin-3 interacts with proteins in the tumor extracellular matrix and colocalizes in the cell lipid nanodomains $[201,268]$. Thus, galectin-3 reaches high protein levels and is protected from the oxidative microenvironment.

Apart from a direct effect on effector T cells, galectin-3 attracts macrophages towards the tumor and promotes their M2 differentiation [269]. Furthermore, other innate immune cells may also be involved in the complete picture of how galectin-3 regulates immunity against cancer [200,205]. Altogether, these arguments clearly state that galectin-3 plays a central role in tumors escaping the anti-tumor effector function. This concept must be taken into consideration in the immunotherapy approaches. Indeed, we recently demonstrated that preconditioning the tumor microenvironment through galectin- 3 downmodulation is a pre-requirement for a long-term protective vaccine strategy in prostate cancer [199].

Galectin-7 is detected in several types of tumors [270-277]. In general, higher histological galectin-7 expression in tumors represents a negative prognostic factor for the survival of cancer patients [274-276]. A transcriptome meta-analysis of cervical cancer cells after ectopic galectin-7 expression demonstrated the regulation of molecular networks, such as metabolism, growth control, invasion, apoptosis, and control of the immune response [278]. This result suggests that galectin-7 plays a role in the tumor microenvironment and immune surveillance. Interestingly, galectin-7 is detected in tumor-associated macrophages [274]. Whether macrophages produce galectin-7 themselves or take it up from neighbor tumor cells remains unknown [22,279], nor is the functional impact of galectin-7 on tumor-associated macrophages. On the other hand, recombinant galectin-7 induces apoptosis of human peripheral T cells [280]. As previously mentioned, the biological concentrations required to induce active galectin isoforms, its topographic cellular distribution, and the oxidative properties of the surrounding environment are important parameters in determining the pro-apoptotic function of this lectin. Apart from controlling the survival of activated T cells, galectin-7 could also be used by tumors to downregulate the cytokine production by T cells, as was demonstrated in other experimental models [281]. Altogether, galectin-7 plays interesting effects on the function and survival of immune cells and should be considered a target for immunotherapies.

Currently, there are no studies evaluating the impact of tumor galectin- 8 on the generation of specific and protective immune responses. Most studies have focused on the role of this protein in tumor metastasis and angiogenesis [103,282-285]. However, inspiration from non-tumoral scenarios can illustrate some potential immune functions of this protein at the tumor site. Galectin- 8 promotes cell death of activated lymphocytes. Indeed, Phytohemagglutinin (PHA)- and CD3/CD28-pre-stimulated human peripheral blood mononuclear cells (PBMCs) become apoptotic after re-stimulation in the presence of recombinant galectin-8 $[286,287]$. Similarly, galectin-8 provides anti-proliferative signals to pre-activated T cells $[286,287]$. Together with those data exposed in the lymph node chapter, these results indicate a dual role of galectin- 8 in T cell function. First, galectin- 8 enhances (co-stimulates) early $\mathrm{T}$ responses in the lymph nodes, especially when the stimulus is limited or when the available $\mathrm{T}$ cell repertoire has low avidity for epitopes (cancer is such a case). Second, galectin- 8 restricts the effector phase of ongoing immune responses through a direct pro-apoptotic effect. However, more experimental data are needed to clarify these biological effects of galectin-8 in cancer.

Contradictory results were observed in several studies that evaluated the prognostic value of the galectin-9 expression in solid tumors. Galectin-9 is a positive prognosis biomarker for patients with some types of cancer [288]. This positive correlation between galectin-9 expression and the overall survival can be accounted by direct effects on tumor cells such as inhibition of metastasis [289,290] and apoptosis induction [291], and also indirectly, through the induction of a more efficient anti-tumor immune response in the 
draining lymph nodes (as stated in the previous chapter). However, as tumor settles as a chronic disease, galectin-9 expression correlates with a poor prognostic value and often associates with immune evasion [110]. Intratumor CD103+ dendritic cells express Tim-3; its interaction with galectin-9 induces deactivation of antigen-presenting cells [292] Interestingly, this subset of dendritic cells is superior in antigen transport from tumors and its cross-presentation in draining lymph nodes [293-295]. In addition, this dendritic cell subtype plays a fundamental role in the local re-stimulation of CD8+ T cells [296]. Furthermore, tumor galectin-9 interacts with dectin- 1 on macrophages to promote their tolerogenic program [297]. Therefore, tumor galectin-9 plays a significant role in controlling myeloid cell's properties, $\mathrm{T}$ cell activation and also in controlling the effector phase of anti-tumor immune responses.

After being activated in the lymph nodes, the migration of lymphocytes into tumors is regulated by galectins. Indeed, tumor-derived galectin-1 remodels the local endothelium in a way that galectin-9 and PD-L1 are upregulated to prevent the lymphocyte infiltration of tumors [174]. Furthermore, galectin-9 contained in tumor-derived exosomes [172] attracts regulatory $\mathrm{T}$ cells towards tumors [298]. As a consequence of their high levels of Tim-3 [299,300], Tregs are very sensitive to the galectin-9 levels in the tumor microenvironment, and this galectin-9/Tim-3 signaling pathway plays a major role in dampening any potentially lymph node-elicited, anti-tumor immune response.

Not only do tumor cells express galectin-9, but this protein is also detected in tumorinfiltrating Tregs $[113,234]$ and tumor-associated macrophages [301]. This particular cellular microenvironment induces arriving $\mathrm{T}$ cells to acquire a characteristic PD1+ Tim3+ CD8+ "exhausted" phenotype, which is associated with failure of T cell proliferation and effector function [301-303]. In addition, it was demonstrated that through interaction with Tim-3, galectin-9 induces apoptosis of effector Th1 lymphocytes [109]. Since galectin-9-mediated cell death is not completely abolished in Tim-3-deficient cells, galectin-9 may also use additional receptors to induce Th1 cell death $[109,227]$. Indeed, tumor galectin-9 also interacts with VISTA in T lymphocytes [114]. This interaction results in the activation of granzyme B inside cytotoxic T cells, causing their apoptosis [114]. Regardless of the mechanism, CD4+ and CD8+ T lymphocytes are both sensitive to galectin-9-mediated apoptosis $[148,220]$. It must be noted that, compared to the other galectin members, lower concentrations of galectin-9 (in the order of $\mathrm{nM}$ ) are required to induce $\mathrm{T}$ cell apoptosis [226]. Galectin-9/Tim-3 interactions occur in lipid rafts [304]; these types of interactions have well-defined topographic locations. In such membrane domains, galectin-9 binds to and increases retention of the protein disulfide isomerase (PDI) at the cell surface, thus controlling the redox status at the plasma membrane [118]. Finally, galectin-9 induction of $\mathrm{T}$ cell apoptosis seems to be finely regulated. Indeed, when expressed at high levels, PD-1 also binds galectin-9 in a glycan-dependent manner, and the co-expression of PD- 1 and Tim-3 protects T cells from galectin-9-induced apoptosis [110]. Through this mechanism, tumor-galectin- 9 eliminates the effectors but not exhausted T cells. These results explain why dysfunctional PD-1+ Tim-3+ T cells persist within the tumor microenvironment and even dominate the intratumoral CD8+ T cell population in several cancers [305-307].

\section{Conclusions and Future Directions}

The low frequency of cancers that develop all along our lives attests to the high efficiency of the immune system to eliminate early transformed cells. Said efficiency occurs even if few immunogenic tumor antigens have been described, and very low numbers of tumor-specific T lymphocytes (mostly with low avidity TCR) are detected in a healthy individual $[169,308]$. Nevertheless, as the tumor is settled and progresses, it develops powerful immunosuppression mechanisms to escape immune attacks. In recent years, much progress has been made in understanding such regulatory mechanisms, the socalled negative checkpoints [309]. However, the partial clinical results obtained with such interventions indicate the need for a more comprehensive understanding of the entire process of anti-tumor immune activation [310]. 
This review highlights that tumor-derived circulating galectins can affect cellular and molecular processes in central and peripheral immune organs to prevent the immune attack of transformed cells. Most of the immunological functions that have been ascribed to galectins in cancer were analyzed in this review. Other functions are likely still worthy of discovery. Among those already known, one of the most studied functions of galectins concerns their ability to induce apoptosis of activated T lymphocytes [311]. A comprehensive evaluation of the existing experimental evidence indicates this effect would be limited to particular structures within the tumor itself. Therein, galectins would reach the necessary concentrations to be active and would be protected from the tumor oxidative environment [118]. On the contrary, biological functions that do not require the formation of lattices between oligomerized galectins and glycans exposed at the cell membrane and the extracellular matrix can be accomplished with lower concentrations of galectins. Therefore, such glycan-independent functions are more easily achievable at tumor-distant tissues (e.g., thymus, draining lymph nodes, and other immune organs in patients harboring a tumor). Among these functions, it is worth mentioning that circulating galectins can be taken up by immune cells [20-22,132]. Once they reach the intracellular space, they interact with cytoplasmic and nuclear molecules, resulting in the control of cell behavior, including cell gene expression (reviewed in [4]). While these non-lectin interactions have received less attention until now, their impact on cancer and other pathologies should not be undervalued. Thus, and without requiring high concentrations, galectins may function as soluble factors affecting each stage of the anti-tumor immune response (T cell migration/activation/effector function). Therefore, galectins represent attractive targets for intervention in cancer immunotherapy.

In this scenario, increasing experimental and clinical evidence indicates that galectins' blockade as monotherapy does not result in any significant advantage for cancer treatment $[42,110,196,292,312,313]$. However, galectins are involved in patient sensitivity or resistance to chemo-, radio-, immune-, anti-angiogenic, and targeted-therapies (reviewed in [314]), promising that effective therapeutic avenues can be achieved by combining galectins' inhibition with the former strategies. It should be noted that said combinatory strategies may involve processes that are immune-dependent as well as others that are not. Among the last ones, we can mention that inhibition of galectin- 1 or galectin-3 both potentiates tumor cell sensitivity to several types of chemotherapies (involving different molecular mechanisms) in a panoply of different cancers [315-335]. On the other hand, administration of galectin-9 increases the sensitivity of chronic myeloid leukemia to the BCR-ABL tyrosine kinase drug imatinib [336]. Many of these described mechanisms support the combination between galectins' inhibition and targeted therapies. In-depth evaluation of these galectins' immune-independent functions is beyond the scope of this review. However, they must be carefully considered to define a personalized combinatorial therapeutic strategy for each patient.

Interestingly, the galectins' inhibition combined with chemotherapy impacts the antitumor immunity (Table 1). In colorectal liver metastasis, single-cell analyses defined two mutually exclusive subsets of tumor cells with divergent response to chemotherapy: the stem-like cells (tumors cells which mainly use the PD-1/PD-L1 pathway to control immunity) and the enterocyte-like cells (which use the Tim-3/galectin-9 pathway to evade immunity) [337]. This observation highlights the impact of chemotherapies on the immune system's ability to attack tumor cells and the need to select combinatorial strategies carefully. In breast cancer, Tim-3 positivity was associated with a worse chemotherapy response [338]. Besides, the use of neutralizing anti-Tim-3 or anti-galectin-9 antibodies improves paclitaxel-based chemotherapy [292]. In said cases, combinatorial treatments induce negative regulation of tumor growth by mechanisms that depend on CD103+ dendritic cells and CD8+ T lymphocytes. Upon such a combinatory treatment, CD103+ dendritic cells express higher levels of CXCL9 chemokine ligand, which attracts CD8+ T lymphocytes towards the tumor. Indeed, not only do increased numbers of CD8+ T cells infiltrate tumors, but these cells also have higher effector functions [292]. 
The combination of galectin-1 inhibition and chemotherapy is another promising strategy for some types of cancers. Indeed, synergic therapeutic effects were reported by combining inhibition of galectin-1 and temozolomide to treat glioblastoma [196]. Such combinatory treatment switches macrophages to M1 polarization, reduces myeloid-derived suppressor and regulatory T cells, and increases tumors' CD4+ and CD8+ T cells infiltration [196].

Interestingly, a positive correlation between circulating galectin-3 levels and paclitaxel resistance was demonstrated in patients with ovarian cancer [339]. In those patients, paclitaxel triggers the TLR-4/MyD88 pathway signaling [340], and exogenous galectin-3 boosts such signaling and promotes higher levels of IL-6, IL-8, and VEGF release [339]. This observation further supports that exogenous galectin-3 plays immune-mediated roles during chemotherapies. In prostate cancer, low doses of docetaxel downregulate tumor galectin-3, even in docetaxel-resistant patients [199]. As a result of the said tumor galectin-3 inhibition, vaccination induces long-term anti-prostate cancer immune protection [199]. This observation highlights a molecular mechanism (mediated by galectins) explaining the synergy between chemotherapy and immunotherapy and the importance of the chronology between both treatments. While inhibition of galectin-3 before vaccination is efficient, all standard clinical assays using the opposite chronology seem not to benefit patients' survival [42].

Galectin inhibition may also be a good strategy combined with radiotherapy. It was demonstrated that radiotherapy increases the tumor levels and secretion of galectin1 [341,342]. High levels of circulating galectin-1 are directly associated with lymphopenia [342] and radioresistance [343] in cancer patients. Furthermore, increased galectin-1 levels resulting from radiation is one of the main causes of poor tumor $\mathrm{T}$ cell infiltration, the tumor endothelium being a major actor in this process [174,344]. Therefore, irradiation creates an unfavorable immune contexture to mount efficient anti-tumor immune responses. Besides, the galectin- 1 blockade can help to reverse such adverse immune scenarios. Accordingly, the use of Anginex (a 33 amino acid galectin-1 inhibitory peptide) combined with a suboptimal dose of radiation causes tumor regression in ovarian, mammary, and squamous cell carcinoma models [313].

Tumor-induced hypoxia is a major driving force that promotes angiogenesis and impairs effector immune responses $[345,346]$. Indeed, in vitro studies have demonstrated that hypoxia promotes the differentiation of PD-1+ Tim-3+ terminally exhausted-like CD8+ $\mathrm{T}$ cells [347]. Furthermore, these exhausted $\mathrm{T}$ cells are resistant to inhibitory checkpoints strategies [348]. Altogether, these data indicate a close regulation between hypoxia, angiogenesis, and immunosuppression. Antiangiogenic agents have been shown to normalize tumor vasculature transiently, which alleviates hypoxia, improves the response to various chemotherapies, and facilitates immune cell infiltration of tumors [349]. In this context, inhibition of galectin-1, similar to other antiangiogenic agents, resulted in transient vessel normalization, as evidenced by vasculature remodeling, increased pericyte coverage of vessels, and T cell infiltration, as well as reduced tumor hypoxia [52,196,350]. Therefore, inhibition of galectins can provide a rational basis to optimize synergistic combinations of antiangiogenic and immunotherapeutic strategies, with the overarching goal of improving the efficacy of these treatments.

Several reports have demonstrated that hormone-sensitive cancers change their galectinome signature during disease progression [255,351,352]. Besides being interesting biomarkers for prognosis and treatment resistance, galectin inhibition in these cancers represents attractive strategies to be combined with hormone-related ones. Although androgen-deprivation therapy, the most common treatment for prostate cancer, initially promotes a robust $\mathrm{T}$ cell infiltrate, $\mathrm{T}$ cell responses are later attenuated due to potent tolerogenic mechanisms tumors develop [353,354]. Given the immunosuppressive functions described for galectins, their participation in such immune phenomena upon androgen deprivation seems plausible. On the other hand, progestagens reconfigure the breast cancer microenvironment, inducing the preferential expansion of myeloid-derived suppressor cells in the spleen and bone marrow of tumor-bearing mice [355]. Furthermore, anti- 
progesterone treatments enhance the anti-tumor immune response and increase sensitivity to the PD-L1 blockade in breast cancers [356]. It is worth noting that progesterone regulates galectin-1 expression in some experimental settings [357,358]. However, there is still a lack of direct evidence between galectins and hormone-dependent immune escape. Indeed, more research is needed to clarify if the galectins' inhibition could have an additive effect on hormone-dependent therapies by preventing immune escape mechanisms induced by such approaches.

Galectin inhibition can also potentiate other immunotherapies. For instance, galectin-1 knockdown synergizes with dendritic cell vaccination and PD-1 blockade in glioblastoma [196]. Data from head and neck cancer demonstrated that galectin-1 inhibition enhances anti-PD1 therapy, suggesting that a combination of galectin-1 inhibitors and antiPD1/PDL1 immune checkpoint synergize for cancer treatment [174]. Indeed, galectin-1 induces resistance to immunotherapy through upregulation of PD-L1 and galectin-9 in the endothelium, resulting in impaired T cell infiltration [174]. In addition, OTX008, a selective galectin-1 inhibitor, inhibits tumor growth in several preclinical studies $[350,359,360]$. In 2012, a phase I clinical trial aiming at evaluating the effects of subcutaneous administration of OTX008 for the treatment of advanced solid tumors was announced (ClinicalTrials.gov: NCT01724320, accessed on 16 July 2021). No results have been communicated up to the present. Although the effects of OTX008 on cancer-associated immune system remain misunderstood, some information can be drawn from leukemia. Indeed, inhibition of leukemia patients' serum galectin-1 by OTX008 abrogates IL-10 production by dendritic and T cells [361], implying this molecule prevents immune deactivation. More studies are needed to fully understand the effects of OTX008 and other galectin-1 inhibitors on the immune system in cancer.

In lung cancer, the accumulation of Tim-3-expressing lymphoid cells and galectin9-expressing monocytic myeloid-derived suppressor cells positively correlates with resistance to anti-PD1 immunotherapy [312]. Accordingly, resistance to anti-PD-1 can be overcome by in vitro blockade of the galectin-9/Tim-3 pathway [362]. This type of results supports a phase I/II trial that currently evaluates the safety and efficacy of MBG453, an antibody against Tim-3, as a single agent and in combination with anti-PD-1 in patients with advanced malignancies (ClinicalTrials.gov: NCT02608268; accessed on 16 July 2021).

Galectin-3 has been involved as a major determinant of cold tumors (those which do not respond to immune checkpoint inhibitors due to the paucity of tumor $\mathrm{T}$ cell infiltration, as happens in prostate and pancreas adenocarcinomas); galectin-3 inhibition can reverse such resistance [363]. Consequently, inhibition of galectin-3 in tumor cells leads to an optimal anti-prostate cancer vaccination [199]. In the same way, galectin-3 inhibition in a pancreatic adenocarcinoma allogeneic vaccine increased disease-free survival in patients [79]. Nevertheless, the impact of galectin-3 inhibition seems to apply to other cancers, including hot cancer. Oral administration of a galectin-3 inhibitor (GB1107) reduced human and mouse lung adenocarcinoma growth and blocked metastasis in a syngeneic model [364]. Treatment with GB1107 increased tumor M1 macrophage polarization and CD8+ T cell infiltration. Furthermore, GB1107 potentiated the effects of a PD-L1 immune checkpoint inhibitor to increase the production of cytotoxic effector molecules [364]. In metastatic melanoma and head and neck cancers, anti-PD-1 treatments are improved by belapectin (GR-MD-02), a galectin-3 inhibitor [365]. This combinatory therapy significantly increases effector memory $\mathrm{T}$ cell activation and reduces monocytic myeloid-derived suppressor cells detected in blood [365]. In non-small cell lung carcinoma, high galectin-3 expression correlated with a poor response to PD-1 blockade in a small cohort of patients [366]. Altogether, the available information underlines the key roles played by galectins in resistance to anti-PD-1 treatments and supports how useful galectin's inhibition could be when associated with a negative checkpoint's blockade. Accordingly, several clinical trials are in progress to treat patients with galectin-3 inhibitors and immunotherapy in different tumor types. These clinical trials include non-small cell lung cancer, squamous cell head and neck cancers (ClinicalTrials.gov: NCT02575404), and melanoma (ClinicalTrials.gov: 
NCT02117362, NCT02575404, both accessed on 16 July 2021) (see Table 1, [42]). Publication of such results will surely clarify the potential role of galectin inhibitors in treating those cancers.

Finally, it is interesting to note that cancer patients following different therapies show better clinical outcomes if they develop galectin-neutralizing antibodies, a natural way to prevent their biological functions [79,367-369]. This argument strongly supports the potential use of galectin inhibitors combined with other approaches to reach more effective treatments for cancer patients.

Even though several galectin inhibitors have been described for more than a decade (Table 2), none has had clinical success [42]. Several reasons may explain such disappointing results. First, most of these inhibitors display weak affinities for galectins [370-374]. Second, in general, the available molecules inhibit various galectin members. This point is challenging since different galectins display high sequence homology $[375,376]$. The development of member-specific inhibitors would be advantageous at reducing the minimal effective dose required to obtain functional results and prevent side effects. Several inhibitors also interact with galectins via their carbohydrate recognition domain (CRD) [377]. In general, such inhibitors are not effective at targeting the CRD-independent functions of galectins [370]. Moreover, since galectins display intra- and extracellular functions, the permeability of these molecules is challenging for their biological effects. Molecular weight is another relevant biochemical parameter to take into account when polysaccharide-derived or polymeric inhibitors are used. Both parameters determine the biodistribution of these molecules, defining which tissues and cells they can access. This review attempts to demonstrate the relevance of these inhibitors reaching the primary and secondary lymphoid organs and the tumor itself. In addition, most glycan-mimicking inhibitors are sensitive to enzymatic hydrolysis by glycosidases, reducing the kinetics of their biological effects [378]. Nevertheless, since galectins are involved in physiological processes, their inhibition can potentially induce side effects. Therefore, it would be desirable to inhibit galectins only at the right place, preventing the systemic biodistribution of these molecules. Considering the abundant experimental evidence supporting galectins as major intermediaries in tumor immune escape, it would be interesting to develop strategies to block them locally in immune-related tissues. As discussed in this review, lymph nodes (where anti-tumor immune responses are elicited) and the tumor itself (where effector function is performed) are attractive anatomic sites where galectins may be inhibited. Finally, it was demonstrated that tumors generate different isoforms of galectins via alternative splicing [379]. This phenomenon can induce inhibitor-resistant galectins. Combinatory strategies are, therefore, logical strategies to prevent resistance selection.

Table 2. The main inhibitors of galectins evaluated for cancer treatment.

\begin{tabular}{|c|c|c|c|c|}
\hline Member & Inhibitor & Reported Biological Effects & Phase of The Study & References \\
\hline \multirow[t]{6}{*}{ Galectin-1 } & Thiodigalactoside (TDG) & $\begin{array}{l}\text { Inhibition of tumor growth and metastasis } \\
\text { Reduction of angiogenesis } \\
\text { Activation of anti-tumor immunosurveillance }\end{array}$ & Pre-clinic & {$[380,381]$} \\
\hline & Anginex ( $\beta$ pep-25) & $\begin{array}{l}\text { Inhibition of tumor growth, angiogenesis and } \\
\text { migration } \\
\text { Increase sensitivity to radiotherapy, chemotherapy } \\
\text { and anti-angiogenesis therapy }\end{array}$ & Pre-clinic & $\begin{array}{c}{[20,254,313,341,382,} \\
383]\end{array}$ \\
\hline & $\begin{array}{l}\text { Anginex analogues (6DBF7; } \\
\text { DB16; DB21) }\end{array}$ & Inhibition of tumor growth and angiogenesis & Pre-clinic & {$[384,385]$} \\
\hline & OTX008 & $\begin{array}{l}\text { Inhibition of tumor growth, angiogenesis and } \\
\text { migration } \\
\text { Synergic effects with chemo- and immunotherapy }\end{array}$ & $\begin{array}{l}\text { Pre-clinic } \\
\text { Phase I }\end{array}$ & $\begin{array}{l}{[315,359,386,387]} \\
\text { NCT01724320 }\end{array}$ \\
\hline & $\begin{array}{l}\text { Galectin-1-specific } \\
\text { neutralizing } \mathrm{mAb}\end{array}$ & Inhibition of tumor growth and angiogenesis & Pre-clinic & {$[25,52,388,389]$} \\
\hline & & Increased immune infiltration of tumors & & \\
\hline \multirow[t]{2}{*}{ Galectins- 1 and -3} & GM-CT-01 (DAVANAT ${ }^{\circledR}$ ) & $\begin{array}{l}\text { Inhibition of tumor growth } \\
\text { Restoration of anti-tumor immune surveillance }\end{array}$ & $\begin{array}{c}\text { Pre-clinic } \\
\text { Phase I and II }\end{array}$ & $\begin{array}{c}{[390]} \\
\text { NCT00054977, } \\
\text { NCT00388700, } \\
\text { NCT00386516, } \\
\text { NCT01723813 }\end{array}$ \\
\hline & $\begin{array}{l}\text { GR-MD- } 02 \\
\text { (modified version of the } \\
\text { DAVANAT®) }\end{array}$ & $\begin{array}{l}\text { Inhibition of tumor growth, improve survival of } \\
\text { tumor-bearing mice } \\
\text { Restoration of anti-tumor immune surveillance, } \\
\text { improve immune checkpoint blockade }\end{array}$ & $\begin{array}{l}\text { Pre-clinic } \\
\text { Phase I }\end{array}$ & $\begin{array}{l}{[365,391]} \\
\text { NCT02117362, } \\
\text { NCT02575404 }\end{array}$ \\
\hline
\end{tabular}


Table 2. Cont.

\begin{tabular}{|c|c|c|c|c|}
\hline Member & Inhibitor & Reported Biological Effects & Phase of The Study & References \\
\hline \multirow[t]{5}{*}{ Galectin-3 } & G3-C12 & $\begin{array}{l}\text { Inhibition of tumor growth and mestastasis } \\
\text { Synergic effects with chemotherapy }\end{array}$ & Pre-clinic & [392-396] \\
\hline & Modified citrus peptin (MCP) & $\begin{array}{l}\text { Inhibition of tumor growth, angiogenesis and } \\
\text { metastasis } \\
\text { Immune activation } \\
\text { Increased sensitivity to chemotherapy }\end{array}$ & Pre-clinic & [397-402] \\
\hline & $\begin{array}{l}\text { PectaSol-C Modified Citrus } \\
\text { Peptin }\end{array}$ & Synergic effects with chemotherapy & Pre-clinic & {$[331,403,404]$} \\
\hline & GCS-100 & $\begin{array}{l}\text { Inhibition of tumor growth } \\
\text { Correction of impaired anti-tumor immune functions }\end{array}$ & $\begin{array}{l}\text { Phase III } \\
\text { Pre-clinic } \\
\text { Phase I }\end{array}$ & $\begin{array}{l}\text { NCT01681823 } \\
{[265,327,405-408]} \\
\text { NCT00609817 }\end{array}$ \\
\hline & & Increased sensitivity to Immuno-chemotherapy & Phase II & \\
\hline Galectin-7 & Inhibitory peptide & $\begin{array}{l}\text { Inhibition of tumor growth and metastasis } \\
\text { Restoration of anti-tumor immune surveillance, } \\
\text { improve immune checkpoint blockade }\end{array}$ & Pre-clinic & {$[370]$} \\
\hline
\end{tabular}

In conclusion, to block galectin-mediated tumor immune escape, the scientific community needs to develop more effective and selective inhibitory reagents, elucidate their precise in vivo mechanism of action, and combine these molecules with other anti-cancer strategies in a logical way.

Author Contributions: D.J.L. and D.C. writing—review and editing. Both authors have read and agreed to the published version of the manuscript.

Funding: Research at the Molecular and Functional Glyco-Oncology laboratory is funded by Worldwide Cancer Research (Scotland, UK), Argentinean National Cancer Institute and Argentinean National Agency for Promotion of Science and Technology (PICT2019-01451).

Institutional Review Board Statement: Not applicable.

Informed Consent Statement: Not applicable.

Acknowledgments: We apologize to the many authors whose papers could not be cited owing to space limitations. We would like to thank all the members of the Molecular and Functional GlycoOncology laboratory for the constant and fruitful scientific discussions. We are also grateful to the staffs of the Flow Cytometry and Animal Core Facilities for helpful assistance in the experimental procedures of our projects. D.J.L. and D.C. are members of the scientific career of the National Research Council (CONICET, Argentina).

Conflicts of Interest: The authors have no financial conflict of interest.

\section{References}

1. Bianconi, E.; Piovesan, A.; Facchin, F.; Beraudi, A.; Casadei, R.; Frabetti, F.; Vitale, L.; Pelleri, M.C.; Tassani, S.; Piva, F.; et al. An estimation of the number of cells in the human body. Ann. Hum. Biol. 2013, 40, 463-471. [CrossRef]

2. Brodin, P.; Davis, M.M. Human immune system variation. Nat. Rev. Immunol. 2017, 17, 21-29. [CrossRef]

3. Laderach, D.J.; Compagno, D.; Toscano, M.A.; Croci, D.O.; Dergan-Dylon, S.; Salatino, M.; Rabinovich, G.A. Dissecting the signal transduction pathways triggered by galectin-glycan interactions in physiological and pathological settings. IUBMB Life 2010, 62, 1-13.

4. Compagno, D.; Jaworski, F.M.; Gentilini, L.; Contrufo, G.; Gonzalez Perez, I.; Elola, M.T.; Pregi, N.; Rabinovich, G.A.; Laderach, D.J. Galectins: Major signaling modulators inside and outside the cell. Curr. Mol. Med. 2014, 14, 630-651. [CrossRef] [PubMed]

5. Nio-Kobayashi, J. Tissue- and cell-specific localization of galectins, beta-galactose-binding animal lectins, and their potential functions in health and disease. Anat. Sci. Int. 2017, 92, 25-36. [CrossRef] [PubMed]

6. Van der Hoeven, N.W.; Hollander, M.R.; Yildirim, C.; Jansen, M.F.; Teunissen, P.F.; Horrevoets, A.J.; van der Pouw Kraan, T.C.; van Royen, N. The emerging role of galectins in cardiovascular disease. Vasc. Pharm. 2016, 81, 31-41. [CrossRef]

7. Sun, M.J.; Cao, Z.Q.; Leng, P. The roles of galectins in hepatic diseases. J. Mol. Histol. 2020, 51, 473-484. [CrossRef] [PubMed]

8. Gu, M.; Mei, X.; Zhao, Y. Galectins as potential pharmacological targets in renal injuries of diverse etiology. Eur. J. Pharm. 2020, 881, 173213. [CrossRef] [PubMed]

9. Wan, L.; Hsu, Y.A.; Wei, C.C.; Liu, F.T. Galectins in allergic inflammatory diseases. Mol. Asp. Med. 2020, 189, 100925. [CrossRef] [PubMed]

10. Ramirez Hernandez, E.; Sanchez-Maldonado, C.; Mayoral Chavez, M.A.; Hernandez-Zimbron, L.F.; Patricio Martinez, A.; Zenteno, E.; Limon Perez de Leon, I.D. The therapeutic potential of galectin-1 and galectin-3 in the treatment of neurodegenerative diseases. Expert Rev. Neurother. 2020, 20, 439-448. [CrossRef] [PubMed] 
11. Salamanna, F.; Veronesi, F.; Frizziero, A.; Fini, M. Role and translational implication of galectins in arthritis pathophysiology and treatment: A systematic literature review. J. Cell. Physiol. 2019, 234, 1588-1605. [CrossRef]

12. Wu, N.L.; Liu, F.T. The expression and function of galectins in skin physiology and pathology. Exp. Derm. 2018, 27, 217-226. [CrossRef] [PubMed]

13. Wang, W.H.; Lin, C.Y.; Chang, M.R.; Urbina, A.N.; Assavalapsakul, W.; Thitithanyanont, A.; Chen, Y.H.; Liu, F.T.; Wang, S.F. The role of galectins in virus infection-A systemic literature review. J. Microbiol. Immunol. Infect. 2020, 53, 925-935. [CrossRef]

14. Shi, W.; Xue, C.; Su, X.Z.; Lu, F. The roles of galectins in parasitic infections. Acta. Trop. 2018, 177, 97-104. [CrossRef]

15. Liu, F.T.; Rabinovich, G.A. Galectins as modulators of tumour progression. Nat. Rev. Cancer 2005, 5, 29-41. [CrossRef] [PubMed]

16. Girotti, M.R.; Salatino, M.; Dalotto-Moreno, T.; Rabinovich, G.A. Sweetening the hallmarks of cancer: Galectins as multifunctional mediators of tumor progression. J. Exp. Med. 2020, 217, e20182041. [CrossRef] [PubMed]

17. Elola, M.T.; Ferragut, F.; Cardenas Delgado, V.M.; Nugnes, L.G.; Gentilini, L.; Laderach, D.; Troncoso, M.F.; Compagno, D.; Wolfenstein-Todel, C.; Rabinovich, G.A. Expression, localization and function of galectin-8, a tandem-repeat lectin, in human tumors. Histol. Histopathol. 2014, 29, 1093-1105. [CrossRef]

18. Thijssen, V.L.; Heusschen, R.; Caers, J.; Griffioen, A.W. Galectin expression in cancer diagnosis and prognosis: A systematic review. Biochim. Biophys. Acta 2015, 1855, 235-247. [CrossRef]

19. Martinez-Bosch, N.; Navarro, P. Galectins in the Tumor Microenvironment: Focus on Galectin-1. Adv. Exp. Med. Biol. 2020, 1259, 17-38. [CrossRef]

20. Thijssen, V.L.; Barkan, B.; Shoji, H.; Aries, I.M.; Mathieu, V.; Deltour, L.; Hackeng, T.M.; Kiss, R.; Kloog, Y.; Poirier, F.; et al. Tumor cells secrete galectin-1 to enhance endothelial cell activity. Cancer Res. 2010, 70, 6216-6224. [CrossRef]

21. Gao, X.; Liu, D.; Fan, Y.; Li, X.; Xue, H.; Ma, Y.; Zhou, Y.; Tai, G. The two endocytic pathways mediated by the carbohydrate recognition domain and regulated by the collagen-like domain of galectin-3 in vascular endothelial cells. PLoS ONE 2012, 7 , e52430. [CrossRef] [PubMed]

22. Lepur, A.; Carlsson, M.C.; Novak, R.; Dumic, J.; Nilsson, U.J.; Leffler, H. Galectin-3 endocytosis by carbohydrate independent and dependent pathways in different macrophage like cell types. Biochim. Biophys. Acta 2012, 1820, 804-818. [CrossRef] [PubMed]

23. Le, Q.T.; Shi, G.; Cao, H.; Nelson, D.W.; Wang, Y.; Chen, E.Y.; Zhao, S.; Kong, C.; Richardson, D.; O’Byrne, K.J.; et al. Galectin-1: A link between tumor hypoxia and tumor immune privilege. J. Clin. Oncol. 2005, 23, 8932-8941. [CrossRef] [PubMed]

24. Zhao, X.Y.; Chen, T.T.; Xia, L.; Guo, M.; Xu, Y.; Yue, F.; Jiang, Y.; Chen, G.Q.; Zhao, K.W. Hypoxia inducible factor-1 mediates expression of galectin-1: The potential role in migration/invasion of colorectal cancer cells. Carcinogenesis 2010, 31, 1367-1375. [CrossRef]

25. Croci, D.O.; Salatino, M.; Rubinstein, N.; Cerliani, J.P.; Cavallin, L.E.; Leung, H.J.; Ouyang, J.; Ilarregui, J.M.; Toscano, M.A.; Domaica, C.I.; et al. Disrupting galectin-1 interactions with N-glycans suppresses hypoxia-driven angiogenesis and tumorigenesis in Kaposi's sarcoma. J. Exp. Med. 2012, 209, 1985-2000. [CrossRef] [PubMed]

26. Ikemori, R.Y.; Machado, C.M.; Furuzawa, K.M.; Nonogaki, S.; Osinaga, E.; Umezawa, K.; de Carvalho, M.A.; Verinaud, L.; Chammas, R. Galectin-3 up-regulation in hypoxic and nutrient deprived microenvironments promotes cell survival. PLoS ONE 2014, 9, e111592. [CrossRef]

27. Saussez, S.; Glinoer, D.; Chantrain, G.; Pattou, F.; Carnaille, B.; Andre, S.; Gabius, H.J.; Laurent, G. Serum galectin-1 and galectin-3 levels in benign and malignant nodular thyroid disease. Thyroid 2008, 18, 705-712. [CrossRef]

28. Cedeno-Laurent, F.; Watanabe, R.; Teague, J.E.; Kupper, T.S.; Clark, R.A.; Dimitroff, C.J. Galectin-1 inhibits the viability, proliferation, and Th1 cytokine production of nonmalignant $\mathrm{T}$ cells in patients with leukemic cutaneous T-cell lymphoma. Blood 2012, 119, 3534-3538. [CrossRef]

29. Martinez-Bosch, N.; Barranco, L.E.; Orozco, C.A.; Moreno, M.; Visa, L.; Iglesias, M.; Oldfield, L.; Neoptolemos, J.P.; Greenhalf, W.; Earl, J.; et al. Increased plasma levels of galectin-1 in pancreatic cancer: Potential use as biomarker. Oncotarget 2018, 9, 32984-32996. [CrossRef] [PubMed]

30. Yi, N.; Zhao, X.; Ji, J.; Xu, M.; Jiao, Y.; Qian, T.; Zhu, S.; Jiang, F.; Chen, J.; Xiao, M. Serum galectin-3 as a biomarker for screening, early diagnosis, prognosis and therapeutic effect evaluation of pancreatic cancer. J. Cell. Mol. Med. 2020, 24, 11583-11591. [CrossRef] [PubMed]

31. Cymbaluk-Ploska, A.; Gargulinska, P.; Kwiatkowski, S.; Pius-Sadowska, E.; Machalinski, B. Could Galectin 3 Be a Good Prognostic Factor in Endometrial Cancer? Diagnostics 2020, 10, 635. [CrossRef]

32. Qi, D.; Zhang, Y.; Li, H.; Wang, R.; Qian, K. Expression and Clinical Significance of Galcetin-3 in the Serum of Non-small Cell Lung Cancer Patients. Zhongguo Fei Ai Za Zhi 2020, 23, 333-336. [CrossRef]

33. Iurisci, I.; Tinari, N.; Natoli, C.; Angelucci, D.; Cianchetti, E.; Iacobelli, S. Concentrations of galectin-3 in the sera of normal controls and cancer patients. Clin. Cancer Res. 2000, 6, 1389-1393.

34. Chen, C.; Duckworth, C.A.; Fu, B.; Pritchard, D.M.; Rhodes, J.M.; Yu, L.G. Circulating galectins $-2,-4$ and -8 in cancer patients make important contributions to the increased circulation of several cytokines and chemokines that promote angiogenesis and metastasis. Br. J. Cancer 2014, 110, 741-752. [CrossRef] [PubMed]

35. Barrow, H.; Guo, X.; Wandall, H.H.; Pedersen, J.W.; Fu, B.; Zhao, Q.; Chen, C.; Rhodes, J.M.; Yu, L.G. Serum galectin-2, -4, and -8 are greatly increased in colon and breast cancer patients and promote cancer cell adhesion to blood vascular endothelium. Clin. Cancer Res. 2011, 17, 7035-7046. [CrossRef] 
36. Seifert, A.M.; Reiche, C.; Heiduk, M.; Tannert, A.; Meinecke, A.C.; Baier, S.; von Renesse, J.; Kahlert, C.; Distler, M.; Welsch, T.; et al. Detection of pancreatic ductal adenocarcinoma with galectin-9 serum levels. Oncogene 2020, 39, 3102-3113. [CrossRef]

37. Wdowiak, K.; Gallego-Colon, E.; Francuz, T.; Czajka-Francuz, P.; Ruiz-Agamez, N.; Kubeczko, M.; Grochola, I.; Wybraniec, M.T.; Chudek, J.; Wojnar, J. Increased serum levels of Galectin-9 in patients with chronic lymphocytic leukemia. Oncol. Lett. 2019, 17, 1019-1029. [CrossRef]

38. Tavares, L.B.; Silva-Filho, A.F.; Martins, M.R.; Vilar, K.M.; Pitta, M.G.R.; Rego, M. Patients with Pancreatic Ductal Adenocarcinoma Have High Serum Galectin-9 Levels: A Sweet Molecule to Keep an Eye On. Pancreas 2018, 47, e59-e60. [CrossRef] [PubMed]

39. Van den Brule, F.A.; Waltregny, D.; Castronovo, V. Increased expression of galectin-1 in carcinoma-associated stroma predicts poor outcome in prostate carcinoma patients. J. Pathol. 2001, 193, 80-87. [CrossRef]

40. Szoke, T.; Kayser, K.; Baumhakel, J.D.; Trojan, I.; Furak, J.; Tiszlavicz, L.; Horvath, A.; Szluha, K.; Gabius, H.J.; Andre, S. Prognostic significance of endogenous adhesion/growth-regulatory lectins in lung cancer. Oncology 2005, 69, 167-174. [CrossRef]

41. Dube-Delarosbil, C.; St-Pierre, Y. The emerging role of galectins in high-fatality cancers. Cell. Mol. Life Sci. 2018, 75, 1215-1226. [CrossRef]

42. Compagno, D.; Tiraboschi, C.; Garcia, J.D.; Rondon, Y.; Corapi, E.; Velazquez, C.; Laderach, D.J. Galectins as Checkpoints of the Immune System in Cancers, Their Clinical Relevance, and Implication in Clinical Trials. Biomolecules 2020, 10, 750. [CrossRef]

43. Rabinovich, G.A.; Toscano, M.A.; Jackson, S.S.; Vasta, G.R. Functions of cell surface galectin-glycoprotein lattices. Curr. Opin. Struct. Biol. 2007, 17, 513-520. [CrossRef]

44. Garner, O.B.; Baum, L.G. Galectin-glycan lattices regulate cell-surface glycoprotein organization and signalling. Biochem. Soc. Trans. 2008, 36, 1472-1477. [CrossRef] [PubMed]

45. Rabinovich, G.A.; Ariel, A.; Hershkoviz, R.; Hirabayashi, J.; Kasai, K.I.; Lider, O. Specific inhibition of T-cell adhesion to extracellular matrix and proinflammatory cytokine secretion by human recombinant galectin-1. Immunology 1999, 97, 100-106. [CrossRef]

46. He, J.; Baum, L.G. Presentation of galectin-1 by extracellular matrix triggers T cell death. J. Biol. Chem. 2004, $279,4705-4712$. [CrossRef] [PubMed]

47. He, J.; Baum, L.G. Galectin interactions with extracellular matrix and effects on cellular function. Methods Enzym. 2006, 417, 247-256. [CrossRef]

48. Fischer, C.; Sanchez-Ruderisch, H.; Welzel, M.; Wiedenmann, B.; Sakai, T.; Andre, S.; Gabius, H.J.; Khachigian, L.; Detjen, K.M.; Rosewicz, S. Galectin-1 interacts with the \{alpha\}5\{beta\}1 fibronectin receptor to restrict carcinoma cell growth via induction of p21 and p27. J. Biol. Chem. 2005, 280, 37266-37277. [CrossRef] [PubMed]

49. Gu, M.; Wang, W.; Song, W.K.; Cooper, D.N.; Kaufman, S.J. Selective modulation of the interaction of alpha 7 beta 1 integrin with fibronectin and laminin by L-14 lectin during skeletal muscle differentiation. J. Cell. Sci. 1994, 107 Pt 1, 175-181. [CrossRef]

50. Elola, M.T.; Wolfenstein-Todel, C.; Troncoso, M.F.; Vasta, G.R.; Rabinovich, G.A. Galectins: Matricellular glycan-binding proteins linking cell adhesion, migration, and survival. Cell. Mol. Life Sci. 2007, 64, 1679-1700. [CrossRef]

51. Hsieh, S.H.; Ying, N.W.; Wu, M.H.; Chiang, W.F.; Hsu, C.L.; Wong, T.Y.; Jin, Y.T.; Hong, T.M.; Chen, Y.L. Galectin-1, a novel ligand of neuropilin-1, activates VEGFR-2 signaling and modulates the migration of vascular endothelial cells. Oncogene 2008, 27, 3746-3753. [CrossRef]

52. Croci, D.O.; Cerliani, J.P.; Dalotto-Moreno, T.; Mendez-Huergo, S.P.; Mascanfroni, I.D.; Dergan-Dylon, S.; Toscano, M.A.; Caramelo, J.J.; Garcia-Vallejo, J.J.; Ouyang, J.; et al. Glycosylation-dependent lectin-receptor interactions preserve angiogenesis in anti-VEGF refractory tumors. Cell 2014, 156, 744-758. [CrossRef]

53. Moiseeva, E.P.; Spring, E.L.; Baron, J.H.; de Bono, D.P. Galectin 1 modulates attachment, spreading and migration of cultured vascular smooth muscle cells via interactions with cellular receptors and components of extracellular matrix. J. Vasc. Res. 1999, 36, 47-58. [CrossRef] [PubMed]

54. Gonzalez, M.M.; Yoshizaki, L.; Wolfenstein-Todel, C.; Fink, N.E. Isolation of galectin-1 from human platelets: Its interaction with actin. Protein J. 2012, 31, 8-14. [CrossRef] [PubMed]

55. Pace, K.E.; Lee, C.; Stewart, P.L.; Baum, L.G. Restricted receptor segregation into membrane microdomains occurs on human T cells during apoptosis induced by galectin-1. J. Immunol. 1999, 163, 3801-3811.

56. Walzel, H.; Schulz, U.; Neels, P.; Brock, J. Galectin-1, a natural ligand for the receptor-type protein tyrosine phosphatase CD45. Immunol. Lett. 1999, 67, 193-202. [CrossRef]

57. Walzel, H.; Blach, M.; Hirabayashi, J.; Kasai, K.I.; Brock, J. Involvement of CD2 and CD3 in galectin-1 induced signaling in human Jurkat T-cells. Glycobiology 2000, 10, 131-140. [CrossRef]

58. Pace, K.E.; Hahn, H.P.; Pang, M.; Nguyen, J.T.; Baum, L.G. CD7 delivers a pro-apoptotic signal during galectin-1-induced T cell death. J. Immunol. 2000, 165, 2331-2334. [CrossRef]

59. Hernandez, J.D.; Nguyen, J.T.; He, J.; Wang, W.; Ardman, B.; Green, J.M.; Fukuda, M.; Baum, L.G. Galectin-1 binds different CD43 glycoforms to cluster CD43 and regulate T cell death. J. Immunol. 2006, 177, 5328-5336. [CrossRef]

60. Chen, I.J.; Chen, H.L.; Demetriou, M. Lateral compartmentalization of T cell receptor versus CD45 by galectin-N-glycan binding and microfilaments coordinate basal and activation signaling. J. Biol. Chem. 2007, 282, 35361-35372. [CrossRef]

61. Ose, R.; Oharaa, O.; Nagase, T. Galectin-1 and Galectin-3 Mediate Protocadherin-24-Dependent Membrane Localization of beta-catenin in Colon Cancer Cell Line HCT116. Curr. Chem. Genom. 2012, 6, 18-26. [CrossRef] [PubMed] 
62. Wang, J.; Lu, Z.H.; Gabius, H.J.; Rohowsky-Kochan, C.; Ledeen, R.W.; Wu, G. Cross-linking of GM1 ganglioside by galectin-1 mediates regulatory $\mathrm{T}$ cell activity involving TRPC5 channel activation: Possible role in suppressing experimental autoimmune encephalomyelitis. J. Immunol. 2009, 182, 4036-4045. [CrossRef]

63. Wu, G.; Lu, Z.H.; Gabius, H.J.; Ledeen, R.W.; Bleich, D. Ganglioside GM1 deficiency in effector T cells from NOD mice induces resistance to regulatory T-cell suppression. Diabetes 2011, 60, 2341-2349. [CrossRef]

64. Paz, A.; Haklai, R.; Elad-Sfadia, G.; Ballan, E.; Kloog, Y. Galectin-1 binds oncogenic H-Ras to mediate Ras membrane anchorage and cell transformation. Oncogene 2001, 20, 7486-7493. [CrossRef] [PubMed]

65. Blazevits, O.; Mideksa, Y.G.; Solman, M.; Ligabue, A.; Ariotti, N.; Nakhaeizadeh, H.; Fansa, E.K.; Papageorgiou, A.C.; Wittinghofer, A.; Ahmadian, M.R.; et al. Galectin-1 dimers can scaffold Raf-effectors to increase H-ras nanoclustering. Sci. Rep. 2016, 6, 24165. [CrossRef] [PubMed]

66. Vyakarnam, A.; Lenneman, A.J.; Lakkides, K.M.; Patterson, R.J.; Wang, J.L. A comparative nuclear localization study of galectin-1 with other splicing components. Exp. Cell. Res. 1998, 242, 419-428. [CrossRef]

67. Park, J.W.; Voss, P.G.; Grabski, S.; Wang, J.L.; Patterson, R.J. Association of galectin-1 and galectin-3 with Gemin4 in complexes containing the SMN protein. Nucleic Acids Res. 2001, 29, 3595-3602. [CrossRef] [PubMed]

68. Patterson, R.J.; Wang, W.; Wang, J.L. Understanding the biochemical activities of galectin-1 and galectin-3 in the nucleus. Glycoconj. J. 2002, 19, 499-506. [CrossRef] [PubMed]

69. Voss, P.G.; Gray, R.M.; Dickey, S.W.; Wang, W.; Park, J.W.; Kasai, K.; Hirabayashi, J.; Patterson, R.J.; Wang, J.L. Dissociation of the carbohydrate-binding and splicing activities of galectin-1. Arch. Biochem. Biophys. 2008, 478, 18-25. [CrossRef] [PubMed]

70. Wang, W.; Park, J.W.; Wang, J.L.; Patterson, R.J. Immunoprecipitation of spliceosomal RNAs by antisera to galectin-1 and galectin-3. Nucleic Acids Res. 2006, 34, 5166-5174. [CrossRef] [PubMed]

71. Barboni, E.A.; Bawumia, S.; Hughes, R.C. Kinetic measurements of binding of galectin 3 to a laminin substratum. Glycoconj. J. 1999, 16, 365-373. [CrossRef]

72. Gordon-Alonso, M.; Hirsch, T.; Wildmann, C.; van der Bruggen, P. Galectin-3 captures interferon-gamma in the tumor matrix reducing chemokine gradient production and T-cell tumor infiltration. Nat. Commun. 2017, 8, 793. [CrossRef]

73. Demetriou, M.; Granovsky, M.; Quaggin, S.; Dennis, J.W. Negative regulation of T-cell activation and autoimmunity by Mgat5 N-glycosylation. Nature 2001, 409, 733-739. [CrossRef] [PubMed]

74. Stillman, B.N.; Hsu, D.K.; Pang, M.; Brewer, C.F.; Johnson, P.; Liu, F.T.; Baum, L.G. Galectin-3 and galectin-1 bind distinct cell surface glycoprotein receptors to induce T cell death. J. Immunol. 2006, 176, 778-789. [CrossRef]

75. Demotte, N.; Stroobant, V.; Courtoy, P.J.; Van Der Smissen, P.; Colau, D.; Luescher, I.F.; Hivroz, C.; Nicaise, J.; Squifflet, J.L.; Mourad, M.; et al. Restoring the association of the $\mathrm{T}$ cell receptor with CD8 reverses anergy in human tumor-infiltrating lymphocytes. Immunity 2008, 28, 414-424. [CrossRef] [PubMed]

76. Petit, A.E.; Demotte, N.; Scheid, B.; Wildmann, C.; Bigirimana, R.; Gordon-Alonso, M.; Carrasco, J.; Valitutti, S.; Godelaine, D.; van der Bruggen, P. A major secretory defect of tumour-infiltrating T lymphocytes due to galectin impairing LFA-1-mediated synapse completion. Nat. Commun. 2016, 7, 12242. [CrossRef]

77. Colomb, F.; Wang, W.; Simpson, D.; Zafar, M.; Beynon, R.; Rhodes, J.M.; Yu, L.G. Galectin-3 interacts with the cell-surface glycoprotein CD146 (MCAM, MUC18) and induces secretion of metastasis-promoting cytokines from vascular endothelial cells. J. Biol. Chem. 2017, 292, 8381-8389. [CrossRef]

78. Burguillos, M.A.; Svensson, M.; Schulte, T.; Boza-Serrano, A.; Garcia-Quintanilla, A.; Kavanagh, E.; Santiago, M.; Viceconte, N.; Oliva-Martin, M.J.; Osman, A.M.; et al. Microglia-Secreted Galectin-3 Acts as a Toll-like Receptor 4 Ligand and Contributes to Microglial Activation. Cell. Rep. 2015, 10, 1626-1638. [CrossRef] [PubMed]

79. Kouo, T.; Huang, L.; Pucsek, A.B.; Cao, M.; Solt, S.; Armstrong, T.; Jaffee, E. Galectin-3 Shapes Antitumor Immune Responses by Suppressing CD8+ T Cells via LAG-3 and Inhibiting Expansion of Plasmacytoid Dendritic Cells. Cancer Immunol. Res. 2015, 3, 412-423. [CrossRef] [PubMed]

80. Markowska, A.I.; Jefferies, K.C.; Panjwani, N. Galectin-3 protein modulates cell surface expression and activation of vascular endothelial growth factor receptor 2 in human endothelial cells. J. Biol. Chem. 2011, 286, 29913-29921. [CrossRef] [PubMed]

81. Magescas, J.; Sengmanivong, L.; Viau, A.; Mayeux, A.; Dang, T.; Burtin, M.; Nilsson, U.J.; Leffler, H.; Poirier, F.; Terzi, F.; et al. Spindle pole cohesion requires glycosylation-mediated localization of NuMA. Sci. Rep. 2017, 7, 1474. [CrossRef] [PubMed]

82. Shalom-Feuerstein, R.; Plowman, S.J.; Rotblat, B.; Ariotti, N.; Tian, T.; Hancock, J.F.; Kloog, Y. K-ras nanoclustering is subverted by overexpression of the scaffold protein galectin-3. Cancer Res. 2008, 68, 6608-6616. [CrossRef] [PubMed]

83. Shimura, T.; Takenaka, Y.; Tsutsumi, S.; Hogan, V.; Kikuchi, A.; Raz, A. Galectin-3, a novel binding partner of beta-catenin. Cancer Res. 2004, 64, 6363-6367. [CrossRef] [PubMed]

84. Shimura, T.; Takenaka, Y.; Fukumori, T.; Tsutsumi, S.; Okada, K.; Hogan, V.; Kikuchi, A.; Kuwano, H.; Raz, A. Implication of galectin-3 in Wnt signaling. Cancer Res. 2005, 65, 3535-3537. [CrossRef]

85. Chen, H.Y.; Fermin, A.; Vardhana, S.; Weng, I.C.; Lo, K.F.; Chang, E.Y.; Maverakis, E.; Yang, R.Y.; Hsu, D.K.; Dustin, M.L.; et al. Galectin-3 negatively regulates TCR-mediated CD4+ T-cell activation at the immunological synapse. Proc. Natl. Acad. Sci. USA 2009, 106, 14496-14501. [CrossRef]

86. Liu, W.; Hsu, D.K.; Chen, H.Y.; Yang, R.Y.; Carraway, K.L., 3rd; Isseroff, R.R.; Liu, F.T. Galectin-3 regulates intracellular trafficking of EGFR through Alix and promotes keratinocyte migration. J. Investig. Derm. 2012, 132, 2828-2837. [CrossRef] 
87. Fei, F.; Joo, E.J.; Tarighat, S.S.; Schiffer, I.; Paz, H.; Fabbri, M.; Abdel-Azim, H.; Groffen, J.; Heisterkamp, N. B-cell precursor acute lymphoblastic leukemia and stromal cells communicate through Galectin-3. Oncotarget 2015, 6, 11378-11394. [CrossRef]

88. Thery, C.; Boussac, M.; Veron, P.; Ricciardi-Castagnoli, P.; Raposo, G.; Garin, J.; Amigorena, S. Proteomic analysis of dendritic cell-derived exosomes: A secreted subcellular compartment distinct from apoptotic vesicles. J. Immunol. 2001, 166, 7309-7318. [CrossRef]

89. Welton, J.L.; Khanna, S.; Giles, P.J.; Brennan, P.; Brewis, I.A.; Staffurth, J.; Mason, M.D.; Clayton, A. Proteomics analysis of bladder cancer exosomes. Mol. Cell. Proteom. 2010, 9, 1324-1338. [CrossRef]

90. Koch, A.; Poirier, F.; Jacob, R.; Delacour, D. Galectin-3, a novel centrosome-associated protein, required for epithelial morphogenesis. Mol. Biol. Cell. 2010, 21, 219-231. [CrossRef]

91. Yu, F.; Finley, R.L., Jr.; Raz, A.; Kim, H.R. Galectin-3 translocates to the perinuclear membranes and inhibits cytochrome c release from the mitochondria. A role for synexin in galectin-3 translocation. J. Biol. Chem. 2002, 277, 15819-15827. [CrossRef]

92. Fukumori, T.; Takenaka, Y.; Oka, N.; Yoshii, T.; Hogan, V.; Inohara, H.; Kanayama, H.O.; Kim, H.R.; Raz, A. Endogenous galectin-3 determines the routing of CD95 apoptotic signaling pathways. Cancer Res. 2004, 64, 3376-3379. [CrossRef]

93. Kim, S.J.; Lee, H.W.; Gu Kang, H.; La, S.H.; Choi, I.J.; Ro, J.Y.; Bresalier, R.S.; Song, J.; Chun, K.H. Ablation of galectin-3 induces p27(KIP1)-dependent premature senescence without oncogenic stress. Cell Death Differ. 2014, 21, 1769-1779. [CrossRef] [PubMed]

94. La, S.H.; Kim, S.J.; Kang, H.G.; Lee, H.W.; Chun, K.H. Ablation of human telomerase reverse transcriptase (hTERT) induces cellular senescence in gastric cancer through a galectin-3 dependent mechanism. Oncotarget 2016, 7, 57117-57130. [CrossRef]

95. Kim, D.W.; Kim, K.H.; Yoo, B.C.; Hong, S.H.; Lim, Y.C.; Shin, Y.K.; Park, J.G. Identification of mitochondrial F(1)F(0)-ATP synthase interacting with galectin-3 in colon cancer cells. Cancer Sci. 2008, 99, 1884-1891. [CrossRef] [PubMed]

96. Dagher, S.F.; Wang, J.L.; Patterson, R.J. Identification of galectin-3 as a factor in pre-mRNA splicing. Proc. Natl. Acad. Sci. USA 1995, 92, 1213-1217. [CrossRef] [PubMed]

97. Haudek, K.C.; Voss, P.G.; Locascio, L.E.; Wang, J.L.; Patterson, R.J. A mechanism for incorporation of galectin-3 into the spliceosome through its association with U1 snRNP. Biochemistry 2009, 48, 7705-7712. [CrossRef]

98. Chen, Y.S.; Chang, C.W.; Tsay, Y.G.; Huang, L.Y.; Wu, Y.C.; Cheng, L.H.; Yang, C.C.; Wu, C.H.; Teo, W.H.; Hung, K.F.; et al. HSP40 co-chaperone protein Tid1 suppresses metastasis of head and neck cancer by inhibiting Galectin-7-TCF3-MMP9 axis signaling. Theranostics 2018, 8, 3841-3855. [CrossRef]

99. Villeneuve, C.; Baricault, L.; Canelle, L.; Barboule, N.; Racca, C.; Monsarrat, B.; Magnaldo, T.; Larminat, F. Mitochondrial proteomic approach reveals galectin-7 as a novel BCL-2 binding protein in human cells. Mol. Biol. Cell. 2011, 22, 999-1013. [CrossRef]

100. Inagaki, Y.; Higashi, K.; Kushida, M.; Hong, Y.Y.; Nakao, S.; Higashiyama, R.; Moro, T.; Itoh, J.; Mikami, T.; Kimura, T.; et al. Hepatocyte growth factor suppresses profibrogenic signal transduction via nuclear export of Smad3 with galectin-7. Gastroenterology 2008, 134, 1180-1190. [CrossRef]

101. Yamamoto, H.; Nishi, N.; Shoji, H.; Itoh, A.; Lu, L.H.; Hirashima, M.; Nakamura, T. Induction of cell adhesion by galectin-8 and its target molecules in Jurkat T-cells. J. Biochem. 2008, 143, 311-324. [CrossRef] [PubMed]

102. Hadari, Y.R.; Arbel-Goren, R.; Levy, Y.; Amsterdam, A.; Alon, R.; Zakut, R.; Zick, Y. Galectin-8 binding to integrins inhibits cell adhesion and induces apoptosis. J. Cell. Sci. 2000, 113 Pt 13, 2385-2397. [CrossRef]

103. Troncoso, M.F.; Ferragut, F.; Bacigalupo, M.L.; Cardenas Delgado, V.M.; Nugnes, L.G.; Gentilini, L.; Laderach, D.; WolfensteinTodel, C.; Compagno, D.; Rabinovich, G.A.; et al. Galectin-8: A matricellular lectin with key roles in angiogenesis. Glycobiology 2014, 24, 907-914. [CrossRef] [PubMed]

104. Fernandez, M.M.; Ferragut, F.; Cardenas Delgado, V.M.; Bracalente, C.; Bravo, A.I.; Cagnoni, A.J.; Nunez, M.; Morosi, L.G.; Quinta, H.R.; Espelt, M.V.; et al. Glycosylation-dependent binding of galectin-8 to activated leukocyte cell adhesion molecule (ALCAM/CD166) promotes its surface segregation on breast cancer cells. Biochim. Biophys. Acta 2016, 1860, 2255-2268. [CrossRef] [PubMed]

105. Cueni, L.N.; Detmar, M. Galectin-8 interacts with podoplanin and modulates lymphatic endothelial cell functions. Exp. Cell. Res. 2009, 315, 1715-1723. [CrossRef] [PubMed]

106. Eshkar Sebban, L.; Ronen, D.; Levartovsky, D.; Elkayam, O.; Caspi, D.; Aamar, S.; Amital, H.; Rubinow, A.; Golan, I.; Naor, D.; et al. The involvement of CD44 and its novel ligand galectin-8 in apoptotic regulation of autoimmune inflammation. J. Immunol. 2007, 179, 1225-1235. [CrossRef] [PubMed]

107. Kim, B.W.; Hong, S.B.; Kim, J.H.; Kwon, D.H.; Song, H.K. Structural basis for recognition of autophagic receptor NDP52 by the sugar receptor galectin-8. Nat. Commun. 2013, 4, 1613. [CrossRef]

108. Hong, M.H.; Weng, I.C.; Li, F.Y.; Lin, W.H.; Liu, F.T. Intracellular galectins sense cytosolically exposed glycans as danger and mediate cellular responses. J. Biomed. Sci. 2021, 28, 16. [CrossRef] [PubMed]

109. Zhu, C.; Anderson, A.C.; Schubart, A.; Xiong, H.; Imitola, J.; Khoury, S.J.; Zheng, X.X.; Strom, T.B.; Kuchroo, V.K. The Tim-3 ligand galectin-9 negatively regulates T helper type 1 immunity. Nat. Immunol. 2005, 6, 1245-1252. [CrossRef]

110. Yang, R.; Sun, L.; Li, C.F.; Wang, Y.H.; Yao, J.; Li, H.; Yan, M.; Chang, W.C.; Hsu, J.M.; Cha, J.H.; et al. Galectin-9 interacts with PD-1 and TIM-3 to regulate T cell death and is a target for cancer immunotherapy. Nat. Commun. 2021, 12, 832. [CrossRef]

111. Nagahara, K.; Arikawa, T.; Oomizu, S.; Kontani, K.; Nobumoto, A.; Tateno, H.; Watanabe, K.; Niki, T.; Katoh, S.; Miyake, M.; et al. Galectin-9 increases Tim-3+ dendritic cells and CD8+ T cells and enhances antitumor immunity via galectin-9-Tim-3 interactions. J. Immunol. 2008, 181, 7660-7669. [CrossRef] [PubMed] 
112. Katoh, S.; Ishii, N.; Nobumoto, A.; Takeshita, K.; Dai, S.Y.; Shinonaga, R.; Niki, T.; Nishi, N.; Tominaga, A.; Yamauchi, A.; et al. Galectin-9 inhibits CD44-hyaluronan interaction and suppresses a murine model of allergic asthma. Am. J. Respir. Crit. Care Med. 2007, 176, 27-35. [CrossRef]

113. Wu, C.; Thalhamer, T.; Franca, R.F.; Xiao, S.; Wang, C.; Hotta, C.; Zhu, C.; Hirashima, M.; Anderson, A.C.; Kuchroo, V.K. Galectin-9-CD44 interaction enhances stability and function of adaptive regulatory T cells. Immunity 2014, 41, 270-282. [CrossRef] [PubMed]

114. Yasinska, I.M.; Meyer, N.H.; Schlichtner, S.; Hussain, R.; Siligardi, G.; Casely-Hayford, M.; Fiedler, W.; Wellbrock, J.; Desmet, C.; Calzolai, L.; et al. Ligand-Receptor Interactions of Galectin-9 and VISTA Suppress Human T Lymphocyte Cytotoxic Activity. Front. Immunol. 2020, 11, 580557. [CrossRef] [PubMed]

115. Madireddi, S.; Eun, S.Y.; Lee, S.W.; Nemcovicova, I.; Mehta, A.K.; Zajonc, D.M.; Nishi, N.; Niki, T.; Hirashima, M.; Croft, M. Galectin-9 controls the therapeutic activity of 4-1BB-targeting antibodies. J. Exp. Med. 2014, 211, 1433-1448. [CrossRef]

116. Vaitaitis, G.M.; Wagner, D.H., Jr. Galectin-9 controls CD40 signaling through a Tim-3 independent mechanism and redirects the cytokine profile of pathogenic T cells in autoimmunity. PLoS ONE 2012, 7, e38708. [CrossRef] [PubMed]

117. Madireddi, S.; Eun, S.Y.; Mehta, A.K.; Birta, A.; Zajonc, D.M.; Niki, T.; Hirashima, M.; Podack, E.R.; Schreiber, T.H.; Croft, M. Regulatory T Cell-Mediated Suppression of Inflammation Induced by DR3 Signaling Is Dependent on Galectin-9. J. Immunol. 2017, 199, 2721-2728. [CrossRef]

118. Bi, S.; Hong, P.W.; Lee, B.; Baum, L.G. Galectin-9 binding to cell surface protein disulfide isomerase regulates the redox environment to enhance T-cell migration and HIV entry. Proc. Natl. Acad. Sci. USA 2011, 108, 10650-10655. [CrossRef] [PubMed]

119. Niki, T.; Tsutsui, S.; Hirose, S.; Aradono, S.; Sugimoto, Y.; Takeshita, K.; Nishi, N.; Hirashima, M. Galectin-9 is a high affinity IgE-binding lectin with anti-allergic effect by blocking IgE-antigen complex formation. J. Biol. Chem. 2009, $284,32344-32352$. [CrossRef]

120. Ohtsubo, K.; Takamatsu, S.; Minowa, M.T.; Yoshida, A.; Takeuchi, M.; Marth, J.D. Dietary and genetic control of glucose transporter 2 glycosylation promotes insulin secretion in suppressing diabetes. Cell 2005, 123, 1307-1321. [CrossRef]

121. Matsuura, A.; Tsukada, J.; Mizobe, T.; Higashi, T.; Mouri, F.; Tanikawa, R.; Yamauchi, A.; Hirashima, M.; Tanaka, Y. Intracellular galectin-9 activates inflammatory cytokines in monocytes. Genes Cells 2009, 14, 511-521. [CrossRef]

122. Den Braber, I.; Mugwagwa, T.; Vrisekoop, N.; Westera, L.; Mogling, R.; de Boer, A.B.; Willems, N.; Schrijver, E.H.; Spierenburg, G.; Gaiser, K.; et al. Maintenance of peripheral naive T cells is sustained by thymus output in mice but not humans. Immunity 2012, 36, 288-297. [CrossRef]

123. Bains, I.; Antia, R.; Callard, R.; Yates, A.J. Quantifying the development of the peripheral naive CD4+ T-cell pool in humans. Blood 2009, 113, 5480-5487. [CrossRef] [PubMed]

124. Seddon, B.; Yates, A.J. The natural history of naive T cells from birth to maturity. Immunol. Rev. 2018, 285, 218-232. [CrossRef]

125. Schreiber, R.D.; Old, L.J.; Smyth, M.J. Cancer immunoediting: Integrating immunity's roles in cancer suppression and promotion. Science 2011, 331, 1565-1570. [CrossRef] [PubMed]

126. Guha, I.; Bhuniya, A.; Shukla, D.; Patidar, A.; Nandi, P.; Saha, A.; Dasgupta, S.; Ganguly, N.; Ghosh, S.; Nair, A.; et al. Tumor Arrests DN2 to DN3 Pro T Cell Transition and Promotes Its Conversion to Thymic Dendritic Cells by Reciprocally Regulating Notch1 and Ikaros Signaling. Front. Immunol. 2020, 11, 898. [CrossRef]

127. Prins, R.M.; Graf, M.R.; Merchant, R.E.; Black, K.L.; Wheeler, C.J. Thymic function and output of recent thymic emigrant T cells during intracranial glioma progression. J. Neurooncol. 2003, 64, 45-54. [CrossRef]

128. Laronne-Bar-On, A.; Zipori, D.; Haran-Ghera, N. Increased regulatory versus effector T cell development is associated with thymus atrophy in mouse models of multiple myeloma. J. Immunol. 2008, 181, 3714-3724. [CrossRef]

129. Li, Y.; Yin, Q.; Yang, L.; Chen, S.; Geng, S.; Wu, X.; Zhong, L.; Schmidt, C.A.; Przybylski, G.K. Reduced levels of recent thymic emigrants in acute myeloid leukemia patients. Cancer Immunol. Immunother. 2009, 58, 1047-1055. [CrossRef] [PubMed]

130. Shanker, A.; Singh, S.M.; Sodhi, A. Ascitic growth of a spontaneous transplantable T cell lymphoma induces thymic involution. 1. Alterations in the CD4/CD8 distribution in thymocytes. Tumour Biol. 2000, 21, 288-298. [CrossRef]

131. Iwamoto, M.; Taguchi, C.; Sasaguri, K.; Kubo, K.Y.; Horie, H.; Yamamoto, T.; Onozuka, M.; Sato, S.; Kadoya, T. The Galectin-1 level in serum as a novel marker for stress. Glycoconj. J. 2010, 27, 419-425. [CrossRef] [PubMed]

132. Sasaguri, K.; Yamada, K.; Narimatsu, Y.; Oonuki, M.; Oishi, A.; Koda, K.; Kubo, K.Y.; Yamamoto, T.; Kadoya, T. Stress-induced galectin-1 influences immune tolerance in the spleen and thymus by modulating CD45 immunoreactive lymphocytes. J. Physiol. Sci. 2017, 67, 489-496. [CrossRef]

133. Daley, S.R.; Teh, C.; Hu, D.Y.; Strasser, A.; Gray, D.H.D. Cell death and thymic tolerance. Immunol. Rev. 2017, 277, 9-20. [CrossRef]

134. Baum, L.G.; Pang, M.; Perillo, N.L.; Wu, T.; Delegeane, A.; Uittenbogaart, C.H.; Fukuda, M.; Seilhamer, J.J. Human thymic epithelial cells express an endogenous lectin, galectin-1, which binds to core 2 O-glycans on thymocytes and T lymphoblastoid cells. J. Exp. Med. 1995, 181, 877-887. [CrossRef] [PubMed]

135. He, J.; Baum, L.G. Endothelial cell expression of galectin-1 induced by prostate cancer cells inhibits T-cell transendothelial migration. Lab. Investig. 2006, 86, 578-590. [CrossRef] [PubMed]

136. Perillo, N.L.; Uittenbogaart, C.H.; Nguyen, J.T.; Baum, L.G. Galectin-1, an endogenous lectin produced by thymic epithelial cells, induces apoptosis of human thymocytes. J. Exp. Med. 1997, 185, 1851-1858. [CrossRef]

137. Vespa, G.N.; Lewis, L.A.; Kozak, K.R.; Moran, M.; Nguyen, J.T.; Baum, L.G.; Miceli, M.C. Galectin-1 specifically modulates TCR signals to enhance TCR apoptosis but inhibit IL-2 production and proliferation. J. Immunol. 1999, 162, 799-806. 
138. Bi, S.; Earl, L.A.; Jacobs, L.; Baum, L.G. Structural features of galectin-9 and galectin-1 that determine distinct T cell death pathways. J. Biol. Chem. 2008, 283, 12248-12258. [CrossRef]

139. Perillo, N.L.; Pace, K.E.; Seilhamer, J.J.; Baum, L.G. Apoptosis of T cells mediated by galectin-1. Nature 1995, 378, 736-739. [CrossRef]

140. Nguyen, J.T.; Evans, D.P.; Galvan, M.; Pace, K.E.; Leitenberg, D.; Bui, T.N.; Baum, L.G. CD45 modulates galectin-1-induced T cell death: Regulation by expression of core 2 O-glycans. J. Immunol. 2001, 167, 5697-5707. [CrossRef]

141. Cho, M.; Cummings, R.D. Galectin-1, a beta-galactoside-binding lectin in Chinese hamster ovary cells. I. Physical and chemical characterization. J. Biol. Chem. 1995, 270, 5198-5206. [CrossRef] [PubMed]

142. Cho, M.; Cummings, R.D. Characterization of monomeric forms of galectin-1 generated by site-directed mutagenesis. Biochemistry 1996, 35, 13081-13088. [CrossRef]

143. Battig, P.; Saudan, P.; Gunde, T.; Bachmann, M.F. Enhanced apoptotic activity of a structurally optimized form of galectin-1. Mol. Immunol. 2004, 41, 9-18. [CrossRef]

144. Villa-Verde, D.M.; Silva-Monteiro, E.; Jasiulionis, M.G.; Farias-De-Oliveira, D.A.; Brentani, R.R.; Savino, W.; Chammas, R. Galectin-3 modulates carbohydrate-dependent thymocyte interactions with the thymic microenvironment. Eur. J. Immunol. 2002, 32, 1434-1444. [CrossRef]

145. Fukumori, T.; Takenaka, Y.; Yoshii, T.; Kim, H.R.; Hogan, V.; Inohara, H.; Kagawa, S.; Raz, A. CD29 and CD7 mediate galectin-3induced type II T-cell apoptosis. Cancer Res. 2003, 63, 8302-8311.

146. Matarrese, P.; Fusco, O.; Tinari, N.; Natoli, C.; Liu, F.T.; Semeraro, M.L.; Malorni, W.; Iacobelli, S. Galectin-3 overexpression protects from apoptosis by improving cell adhesion properties. Int. J. Cancer 2000, 85, 545-554. [CrossRef]

147. Yang, R.Y.; Hsu, D.K.; Liu, F.T. Expression of galectin-3 modulates T-cell growth and apoptosis. Proc. Natl. Acad. Sci. USA 1996, 93, 6737-6742. [CrossRef] [PubMed]

148. Kashio, Y.; Nakamura, K.; Abedin, M.J.; Seki, M.; Nishi, N.; Yoshida, N.; Nakamura, T.; Hirashima, M. Galectin-9 induces apoptosis through the calcium-calpain-caspase-1 pathway. J. Immunol. 2003, 170, 3631-3636. [CrossRef] [PubMed]

149. Tribulatti, M.V.; Mucci, J.; Cattaneo, V.; Aguero, F.; Gilmartin, T.; Head, S.R.; Campetella, O. Galectin-8 induces apoptosis in the CD4(high)CD8(high) thymocyte subpopulation. Glycobiology 2007, 17, 1404-1412. [CrossRef] [PubMed]

150. Wada, J.; Ota, K.; Kumar, A.; Wallner, E.I.; Kanwar, Y.S. Developmental regulation, expression, and apoptotic potential of galectin-9, a beta-galactoside binding lectin. J. Clin. Investig. 1997, 99, 2452-2461. [CrossRef] [PubMed]

151. Savino, W.; Mendes-Da-Cruz, D.A.; Smaniotto, S.; Silva-Monteiro, E.; Villa-Verde, D.M. Molecular mechanisms governing thymocyte migration: Combined role of chemokines and extracellular matrix. J. Leukoc. Biol. 2004, 75, 951-961. [CrossRef] [PubMed]

152. Liu, S.D.; Whiting, C.C.; Tomassian, T.; Pang, M.; Bissel, S.J.; Baum, L.G.; Mossine, V.V.; Poirier, F.; Huflejt, M.E.; Miceli, M.C. Endogenous galectin-1 enforces class I-restricted TCR functional fate decisions in thymocytes. Blood 2008, 112, 120-130. [CrossRef]

153. Martinez Allo, V.C.; Hauk, V.; Sarbia, N.; Pinto, N.A.; Croci, D.O.; Dalotto-Moreno, T.; Morales, R.M.; Gatto, S.G.; Manselle Cocco, M.N.; Stupirski, J.C.; et al. Suppression of age-related salivary gland autoimmunity by glycosylation-dependent galectin-1-driven immune inhibitory circuits. Proc. Natl. Acad. Sci. USA 2020, 117, 6630-6639. [CrossRef] [PubMed]

154. Fernandez-Perez, R.; Lopez-Santalla, M.; Sanchez-Dominguez, R.; Alberquilla, O.; Gutierrez-Canas, I.; Juarranz, Y.; Bueren, J.A.; Garin, M.I. Enhanced Susceptibility of Galectin-1 Deficient Mice to Experimental Colitis. Front. Immunol. 2021, $12,687443$. [CrossRef]

155. Oliveira-de-Abreu, E.; Silva-Dos-Santos, D.; Lepletier, A.; Ramos, T.D.P.; Ferreira-Reis, R.; Vasconcelos-Fontes, L.; Ramos, M.T.; Torres, R.C.; Cotta-de-Almeida, V.; Carvalho, V.F.; et al. Lack of Galectin-3 Disrupts Thymus Homeostasis in Association to Increase of Local and Systemic Glucocorticoid Levels and Steroidogenic Machinery. Front. Endocrinol. 2018, 9, 365. [CrossRef]

156. Magnaldo, T.; Fowlis, D.; Darmon, M. Galectin-7, a marker of all types of stratified epithelia. Differentiation 1998, 63, 159-168. [CrossRef] [PubMed]

157. Vyakarnam, A.; Dagher, S.F.; Wang, J.L.; Patterson, R.J. Evidence for a role for galectin-1 in pre-mRNA splicing. Mol. Cell. Biol. 1997, 17, 4730-4737. [CrossRef] [PubMed]

158. Haudek, K.C.; Voss, P.G.; Wang, J.L.; Patterson, R.J. A 10 S galectin-3-U1 snRNP complex assembles into active spliceosomes. Nucleic Acids Res. 2016, 44, 6391-6397. [CrossRef]

159. Liu, F.T.; Patterson, R.J.; Wang, J.L. Intracellular functions of galectins. Biochim. Biophys. Acta 2002, 1572, 263-273. [CrossRef]

160. Kang, H.G.; Kim, W.J.; Chun, K.H.; Kim, S.J. Galectin-3 Interacts with C/EBPbeta and Upregulates Hyaluronan-Mediated Motility Receptor Expression in Gastric Cancer. Mol. Cancer Res. 2020, 18, 403-413. [CrossRef]

161. Kim, S.J.; Chun, K.H. Non-classical role of Galectin-3 in cancer progression: Translocation to nucleus by carbohydrate-recognition independent manner. BMB Rep. 2020, 53, 173-180. [CrossRef] [PubMed]

162. Goncalves, P.; Ferrarini, M.; Molina-Paris, C.; Lythe, G.; Vasseur, F.; Lim, A.; Rocha, B.; Azogui, O. A new mechanism shapes the naive CD8(+) T cell repertoire: The selection for full diversity. Mol. Immunol. 2017, 85, 66-80. [CrossRef] [PubMed]

163. De Greef, P.C.; Oakes, T.; Gerritsen, B.; Ismail, M.; Heather, J.M.; Hermsen, R.; Chain, B.; de Boer, R.J. The naive T-cell receptor repertoire has an extremely broad distribution of clone sizes. Elife 2020, 9, e49900. [CrossRef] [PubMed]

164. Yates, A.J. Theories and quantification of thymic selection. Front. Immunol. 2014, 5, 13. [CrossRef] [PubMed]

165. Ott, P.A.; Hu, Z.; Keskin, D.B.; Shukla, S.A.; Sun, J.; Bozym, D.J.; Zhang, W.; Luoma, A.; Giobbie-Hurder, A.; Peter, L.; et al. An immunogenic personal neoantigen vaccine for patients with melanoma. Nature 2017, 547, 217-221. [CrossRef] 
166. George, J.T.; Kessler, D.A.; Levine, H. Effects of thymic selection on T cell recognition of foreign and tumor antigenic peptides. Proc. Natl. Acad. Sci. USA 2017, 114, E7875-E7881. [CrossRef]

167. Pittet, M.J.; Valmori, D.; Dunbar, P.R.; Speiser, D.E.; Lienard, D.; Lejeune, F.; Fleischhauer, K.; Cerundolo, V.; Cerottini, J.C.; Romero, P. High frequencies of naive Melan-A/MART-1-specific CD8(+) T cells in a large proportion of human histocompatibility leukocyte antigen (HLA)-A2 individuals. J. Exp. Med. 1999, 190, 705-715. [CrossRef]

168. Germeau, C.; Ma, W.; Schiavetti, F.; Lurquin, C.; Henry, E.; Vigneron, N.; Brasseur, F.; Lethe, B.; De Plaen, E.; Velu, T.; et al. High frequency of antitumor $\mathrm{T}$ cells in the blood of melanoma patients before and after vaccination with tumor antigens. J. Exp. Med. 2005, 201, 241-248. [CrossRef]

169. Pinho, M.P.; Patente, T.A.; Flatow, E.A.; Sallusto, F.; Barbuto, J.A.M. Frequency determination of breast tumor-reactive CD4 and CD8 T cells in humans: Unveiling the antitumor immune response. Oncoimmunology 2019, 8, 1607674. [CrossRef]

170. Alexandrov, L.B.; Nik-Zainal, S.; Wedge, D.C.; Aparicio, S.A.; Behjati, S.; Biankin, A.V.; Bignell, G.R.; Bolli, N.; Borg, A.; Borresen-Dale, A.L.; et al. Signatures of mutational processes in human cancer. Nature 2013, 500, 415-421. [CrossRef]

171. Janeway, C.A.J.; Travers, P.; Walport, M.; Shlomchik, M. Immunobiology, 5th ed.; Garland Publishing: New York, NY, USA, 2001; ISBN 10:0-8153-3642-X.

172. Keryer-Bibens, C.; Pioche-Durieu, C.; Villemant, C.; Souquere, S.; Nishi, N.; Hirashima, M.; Middeldorp, J.; Busson, P. Exosomes released by EBV-infected nasopharyngeal carcinoma cells convey the viral latent membrane protein 1 and the immunomodulatory protein galectin 9. BMC Cancer 2006, 6, 283. [CrossRef]

173. Norling, L.V.; Sampaio, A.L.; Cooper, D.; Perretti, M. Inhibitory control of endothelial galectin-1 on in vitro and in vivo lymphocyte trafficking. FASEB J. 2008, 22, 682-690. [CrossRef]

174. Nambiar, D.K.; Aguilera, T.; Cao, H.; Kwok, S.; Kong, C.; Bloomstein, J.; Wang, Z.; Rangan, V.S.; Jiang, D.; von Eyben, R.; et al. Galectin-1-driven T cell exclusion in the tumor endothelium promotes immunotherapy resistance. J. Clin. Investig. 2019, 129, 5553-5567. [CrossRef]

175. Williams, S.P.; Odell, A.F.; Karnezis, T.; Farnsworth, R.H.; Gould, C.M.; Li, J.; Paquet-Fifield, S.; Harris, N.C.; Walter, A.; Gregory, J.L.; et al. Genome-wide functional analysis reveals central signaling regulators of lymphatic endothelial cell migration and remodeling. Sci. Signal. 2017, 10. [CrossRef]

176. Thiemann, S.; Man, J.H.; Chang, M.H.; Lee, B.; Baum, L.G. Galectin-1 regulates tissue exit of specific dendritic cell populations. J. Biol. Chem. 2015, 290, 22662-22677. [CrossRef] [PubMed]

177. Ilarregui, J.M.; Croci, D.O.; Bianco, G.A.; Toscano, M.A.; Salatino, M.; Vermeulen, M.E.; Geffner, J.R.; Rabinovich, G.A. Tolerogenic signals delivered by dendritic cells to $\mathrm{T}$ cells through a galectin-1-driven immunoregulatory circuit involving interleukin 27 and interleukin 10. Nat. Immunol. 2009, 10, 981-991. [CrossRef]

178. Peng, Y.; Ye, Y.; Jia, J.; He, Y.; Yang, Z.; Zhu, X.; Huang, H.; Wang, W.; Geng, L.; Yin, S.; et al. Galectin-1-induced tolerogenic dendritic cells combined with apoptotic lymphocytes prolong liver allograft survival. Int. Immunopharmacol. 2018, 65, 470-482. [CrossRef] [PubMed]

179. Ortner, D.; Grabher, D.; Hermann, M.; Kremmer, E.; Hofer, S.; Heufler, C. The adaptor protein Bam32 in human dendritic cells participates in the regulation of MHC class I-induced CD8+ T cell activation. J. Immunol. 2011, 187, 3972-3978. [CrossRef] [PubMed]

180. Tesone, A.J.; Rutkowski, M.R.; Brencicova, E.; Svoronos, N.; Perales-Puchalt, A.; Stephen, T.L.; Allegrezza, M.J.; Payne, K.K.; Nguyen, J.M.; Wickramasinghe, J.; et al. Satb1 Overexpression Drives Tumor-Promoting Activities in Cancer-Associated Dendritic Cells. Cell. Rep. 2016, 14, 1774-1786. [CrossRef]

181. Rubinstein, N.; Alvarez, M.; Zwirner, N.W.; Toscano, M.A.; Ilarregui, J.M.; Bravo, A.; Mordoh, J.; Fainboim, L.; Podhajcer, O.L.; Rabinovich, G.A. Targeted inhibition of galectin-1 gene expression in tumor cells results in heightened T cell-mediated rejection; A potential mechanism of tumor-immune privilege. Cancer Cell. 2004, 5, 241-251. [CrossRef]

182. Soldati, R.; Berger, E.; Zenclussen, A.C.; Jorch, G.; Lode, H.N.; Salatino, M.; Rabinovich, G.A.; Fest, S. Neuroblastoma triggers an immunoevasive program involving galectin-1-dependent modulation of T cell and dendritic cell compartments. Int. J. Cancer 2012, 131, 1131-1141. [CrossRef]

183. Cedeno-Laurent, F.; Opperman, M.; Barthel, S.R.; Kuchroo, V.K.; Dimitroff, C.J. Galectin-1 triggers an immunoregulatory signature in Th cells functionally defined by IL-10 expression. J. Immunol. 2012, 188, 3127-3137. [CrossRef]

184. Juszczynski, P.; Ouyang, J.; Monti, S.; Rodig, S.J.; Takeyama, K.; Abramson, J.; Chen, W.; Kutok, J.L.; Rabinovich, G.A.; Shipp, M.A. The AP1-dependent secretion of galectin-1 by Reed Sternberg cells fosters immune privilege in classical Hodgkin lymphoma. Proc. Natl. Acad. Sci. USA 2007, 104, 13134-13139. [CrossRef]

185. Motran, C.C.; Molinder, K.M.; Liu, S.D.; Poirier, F.; Miceli, M.C. Galectin-1 functions as a Th2 cytokine that selectively induces Th1 apoptosis and promotes Th2 function. Eur. J. Immunol. 2008, 38, 3015-3027. [CrossRef]

186. Tang, D.; Gao, J.; Wang, S.; Yuan, Z.; Ye, N.; Chong, Y.; Xu, C.; Jiang, X.; Li, B.; Yin, W.; et al. Apoptosis and anergy of T cell induced by pancreatic stellate cells-derived galectin-1 in pancreatic cancer. Tumour Biol. 2015, 36, 5617-5626. [CrossRef] [PubMed]

187. Liu, S.D.; Tomassian, T.; Bruhn, K.W.; Miller, J.F.; Poirier, F.; Miceli, M.C. Galectin-1 tunes TCR binding and signal transduction to regulate CD8 burst size. J. Immunol. 2009, 182, 5283-5295. [CrossRef] [PubMed]

188. Bunn, P.T.; Montes de Oca, M.; Rivera, F.L.; Kumar, R.; Edwards, C.L.; Faleiro, R.J.; Ng, S.S.; Sheel, M.; Wang, Y.; Amante, F.H.; et al. Galectin-1 Impairs the Generation of Anti-Parasitic Th1 Cell Responses in the Liver during Experimental Visceral Leishmaniasis. Front. Immunol. 2017, 8, 1307. [CrossRef] 
189. Lonnberg, T.; Svensson, V.; James, K.R.; Fernandez-Ruiz, D.; Sebina, I.; Montandon, R.; Soon, M.S.; Fogg, L.G.; Nair, A.S.; Liligeto, U.; et al. Single-cell RNA-seq and computational analysis using temporal mixture modelling resolves Th1/Tfh fate bifurcation in malaria. Sci. Immunol. 2017, 2, eaal2192. [CrossRef]

190. Corapi, E.; Carrizo, G.; Compagno, D.; Laderach, D. Endogenous Galectin-1 in T Lymphocytes Regulates Anti-prostate Cancer Immunity. Front. Immunol. 2018, 9, 2190. [CrossRef] [PubMed]

191. Dalotto-Moreno, T.; Croci, D.O.; Cerliani, J.P.; Martinez-Allo, V.C.; Dergan-Dylon, S.; Mendez Huergo, S.P.; Stupirski, J.C.; Mazal, D.; Osinaga, E.; Toscano, M.A.; et al. Targeting galectin-1 overcomes breast cancer associated immunosuppression and prevents metastatic disease. Cancer Res. 2013, 73, 1107-1117. [CrossRef]

192. Garin, M.I.; Chu, C.C.; Golshayan, D.; Cernuda-Morollon, E.; Wait, R.; Lechler, R.I. Galectin-1: A key effector of regulation mediated by CD4+CD25+ T cells. Blood 2007, 109, 2058-2065. [CrossRef]

193. Cagnoni, A.J.; Giribaldi, M.L.; Blidner, A.G.; Cutine, A.M.; Gatto, S.G.; Morales, R.M.; Salatino, M.; Abba, M.C.; Croci, D.O.; Marino, K.V.; et al. Galectin-1 fosters an immunosuppressive microenvironment in colorectal cancer by reprogramming CD8(+) regulatory T cells. Proc. Natl. Acad. Sci. USA 2021, 118, e2102950118. [CrossRef]

194. Verschuere, T.; Toelen, J.; Maes, W.; Poirier, F.; Boon, L.; Tousseyn, T.; Mathivet, T.; Gerhardt, H.; Mathieu, V.; Kiss, R.; et al. Glioma-derived galectin-1 regulates innate and adaptive antitumor immunity. Int. J. Cancer 2014, 134, 873-884. [CrossRef]

195. Baker, G.J.; Chockley, P.; Zamler, D.; Castro, M.G.; Lowenstein, P.R. Natural killer cells require monocytic Gr-1(+)/CD11b(+) myeloid cells to eradicate orthotopically engrafted glioma cells. Oncoimmunology 2016, 5, e1163461. [CrossRef] [PubMed]

196. Van Woensel, M.; Mathivet, T.; Wauthoz, N.; Rosiere, R.; Garg, A.D.; Agostinis, P.; Mathieu, V.; Kiss, R.; Lefranc, F.; Boon, L.; et al. Sensitization of glioblastoma tumor micro-environment to chemo- and immunotherapy by Galectin-1 intranasal knock-down strategy. Sci. Rep. 2017, 7, 1217. [CrossRef] [PubMed]

197. Orozco, C.A.; Martinez-Bosch, N.; Guerrero, P.E.; Vinaixa, J.; Dalotto-Moreno, T.; Iglesias, M.; Moreno, M.; Djurec, M.; Poirier, F.; Gabius, H.J.; et al. Targeting galectin-1 inhibits pancreatic cancer progression by modulating tumor-stroma crosstalk. Proc. Natl. Acad. Sci. USA 2018, 115, E3769-E3778. [CrossRef]

198. Chen, Q.; Han, B.; Meng, X.; Duan, C.; Yang, C.; Wu, Z.; Magafurov, D.; Zhao, S.; Safin, S.; Jiang, C.; et al. Immunogenomic analysis reveals LGALS1 contributes to the immune heterogeneity and immunosuppression in glioma. Int. J. Cancer 2019, 145, 517-530. [CrossRef] [PubMed]

199. Tiraboschi, C.; Gentilini, L.; Corapi, E.; Jaworski, F.M.; Velazquez, C.; Chauchereau, A.; Laderach, D.J.; Compagno, D. Combining inhibition of Galectin-3 with and before a therapeutic vaccination is critical for the prostate-tumor free outcome. J. Immunother. Cancer 2020, 8, e001535. [CrossRef]

200. Radosavljevic, G.; Jovanovic, I.; Majstorovic, I.; Mitrovic, M.; Lisnic, V.J.; Arsenijevic, N.; Jonjic, S.; Lukic, M.L. Deletion of galectin-3 in the host attenuates metastasis of murine melanoma by modulating tumor adhesion and NK cell activity. Clin. Exp. Metastasis 2011, 28, 451-462. [CrossRef]

201. Hsu, D.K.; Chernyavsky, A.I.; Chen, H.Y.; Yu, L.; Grando, S.A.; Liu, F.T. Endogenous galectin-3 is localized in membrane lipid rafts and regulates migration of dendritic cells. J. Investig. Derm. 2009, 129, 573-583. [CrossRef]

202. Breuilh, L.; Vanhoutte, F.; Fontaine, J.; van Stijn, C.M.; Tillie-Leblond, I.; Capron, M.; Faveeuw, C.; Jouault, T.; van Die, I.; Gosset, P.; et al. Galectin-3 modulates immune and inflammatory responses during helminthic infection: Impact of galectin-3 deficiency on the functions of dendritic cells. Infect. Immun. 2007, 75, 5148-5157. [CrossRef] [PubMed]

203. Wu, S.Y.; Yu, J.S.; Liu, F.T.; Miaw, S.C.; Wu-Hsieh, B.A. Galectin-3 negatively regulates dendritic cell production of IL-23/IL-17-axis cytokines in infection by Histoplasma capsulatum. J. Immunol. 2013, 190, 3427-3437. [CrossRef] [PubMed]

204. Fermin Lee, A.; Chen, H.Y.; Wan, L.; Wu, S.Y.; Yu, J.S.; Huang, A.C.; Miaw, S.C.; Hsu, D.K.; Wu-Hsieh, B.A.; Liu, F.T. Galectin-3 modulates Th17 responses by regulating dendritic cell cytokines. Am. J. Pathol. 2013, 183, 1209-1222. [CrossRef] [PubMed]

205. Chaudhari, A.D.; Gude, R.P.; Kalraiya, R.D.; Chiplunkar, S.V. Endogenous galectin-3 expression levels modulate immune responses in galectin-3 transgenic mice. Mol. Immunol. 2015, 68, 300-311. [CrossRef] [PubMed]

206. Amani, M.F.; Rolig, A.S.; Redmond, W.L. Intracellular Galectin-3 Is Essential for OX40-Mediated Memory CD8(+) T Cell Development. J. Immunol. 2020, 205, 1857-1866. [CrossRef]

207. Joo, H.G.; Goedegebuure, P.S.; Sadanaga, N.; Nagoshi, M.; von Bernstorff, W.; Eberlein, T.J. Expression and function of galectin-3, a beta-galactoside-binding protein in activated T lymphocytes. J. Leukoc. Biol. 2001, 69, 555-564.

208. Melief, S.M.; Visser, M.; van der Burg, S.H.; Verdegaal, E.M.E. IDO and galectin-3 hamper the ex vivo generation of clinical grade tumor-specific T cells for adoptive cell therapy in metastatic melanoma. Cancer Immunol. Immunother. 2017, 66, 913-926. [CrossRef]

209. Chen, W.S.; Cao, Z.; Sugaya, S.; Lopez, M.J.; Sendra, V.G.; Laver, N.; Leffler, H.; Nilsson, U.J.; Fu, J.; Song, J.; et al. Pathological lymphangiogenesis is modulated by galectin-8-dependent crosstalk between podoplanin and integrin-associated VEGFR-3. Nat. Commun. 2016, 7, 11302. [CrossRef]

210. Bieniasz-Krzywiec, P.; Martin-Perez, R.; Ehling, M.; Garcia-Caballero, M.; Pinioti, S.; Pretto, S.; Kroes, R.; Aldeni, C.; Di Matteo, M.; Prenen, H.; et al. Podoplanin-Expressing Macrophages Promote Lymphangiogenesis and Lymphoinvasion in Breast Cancer. Cell Metab. 2019, 30, 917-936.e10. [CrossRef]

211. Prato, C.A.; Carabelli, J.; Campetella, O.; Tribulatti, M.V. Galectin-8 Enhances T cell Response by Promotion of Antigen Internalization and Processing. iScience 2020, 23, 101278. [CrossRef] 
212. Carabelli, J.; Quattrocchi, V.; D'Antuono, A.; Zamorano, P.; Tribulatti, M.V.; Campetella, O. Galectin-8 activates dendritic cells and stimulates antigen-specific immune response elicitation. J. Leukoc. Biol. 2017, 102, 1237-1247. [CrossRef]

213. Carabelli, J.; Prato, C.A.; Sanmarco, L.M.; Aoki, M.P.; Campetella, O.; Tribulatti, M.V. Interleukin-6 signalling mediates Galectin-8 co-stimulatory activity of antigen-specific CD4 T-cell response. Immunology 2018, 155, 379-386. [CrossRef]

214. Tribulatti, M.V.; Cattaneo, V.; Hellman, U.; Mucci, J.; Campetella, O. Galectin-8 provides costimulatory and proliferative signals to T lymphocytes. J. Leukoc. Biol. 2009, 86, 371-380. [CrossRef] [PubMed]

215. Sampson, J.F.; Suryawanshi, A.; Chen, W.S.; Rabinovich, G.A.; Panjwani, N. Galectin-8 promotes regulatory T-cell differentiation by modulating IL-2 and TGFbeta signaling. Immunol. Cell. Biol. 2016, 94, 220. [CrossRef]

216. Tribulatti, M.V.; Figini, M.G.; Carabelli, J.; Cattaneo, V.; Campetella, O. Redundant and antagonistic functions of galectin-1, -3 , and -8 in the elicitation of T cell responses. J. Immunol. 2012, 188, 2991-2999. [CrossRef] [PubMed]

217. Kadowaki, T.; Arikawa, T.; Shinonaga, R.; Oomizu, S.; Inagawa, H.; Soma, G.; Niki, T.; Hirashima, M. Galectin-9 signaling prolongs survival in murine lung-cancer by inducing macrophages to differentiate into plasmacytoid dendritic cell-like macrophages. Clin. Immunol. 2012, 142, 296-307. [CrossRef]

218. Nobumoto, A.; Nagahara, K.; Oomizu, S.; Katoh, S.; Nishi, N.; Takeshita, K.; Niki, T.; Tominaga, A.; Yamauchi, A.; Hirashima, M. Galectin-9 suppresses tumor metastasis by blocking adhesion to endothelium and extracellular matrices. Glycobiology 2008, 18, 735-744. [CrossRef] [PubMed]

219. Nobumoto, A.; Oomizu, S.; Arikawa, T.; Katoh, S.; Nagahara, K.; Miyake, M.; Nishi, N.; Takeshita, K.; Niki, T.; Yamauchi, A.; et al. Galectin-9 expands unique macrophages exhibiting plasmacytoid dendritic cell-like phenotypes that activate NK cells in tumorbearing mice. Clin. Immunol. 2009, 130, 322-330. [CrossRef]

220. Wang, F.; He, W.; Zhou, H.; Yuan, J.; Wu, K.; Xu, L.; Chen, Z.K. The Tim-3 ligand galectin-9 negatively regulates CD8+ alloreactive T cell and prolongs survival of skin graft. Cell. Immunol. 2007, 250, 68-74. [CrossRef]

221. Seki, M.; Oomizu, S.; Sakata, K.M.; Sakata, A.; Arikawa, T.; Watanabe, K.; Ito, K.; Takeshita, K.; Niki, T.; Saita, N.; et al. Galectin-9 suppresses the generation of Th17, promotes the induction of regulatory $\mathrm{T}$ cells, and regulates experimental autoimmune arthritis. Clin. Immunol. 2008, 127, 78-88. [CrossRef]

222. Sharma, S.; Sundararajan, A.; Suryawanshi, A.; Kumar, N.; Veiga-Parga, T.; Kuchroo, V.K.; Thomas, P.G.; Sangster, M.Y.; Rouse, B.T. $\mathrm{T}$ cell immunoglobulin and mucin protein-3 (Tim-3)/Galectin-9 interaction regulates influenza A virus-specific humoral and CD8 T-cell responses. Proc. Natl. Acad. Sci. USA 2011, 108, 19001-19006. [CrossRef]

223. Reddy, P.B.; Sehrawat, S.; Suryawanshi, A.; Rajasagi, N.K.; Mulik, S.; Hirashima, M.; Rouse, B.T. Influence of galectin-9/Tim-3 interaction on herpes simplex virus-1 latency. J. Immunol. 2011, 187, 5745-5755. [CrossRef] [PubMed]

224. Moritoki, M.; Kadowaki, T.; Niki, T.; Nakano, D.; Soma, G.; Mori, H.; Kobara, H.; Masaki, T.; Kohno, M.; Hirashima, M. Galectin-9 ameliorates clinical severity of MRL/lpr lupus-prone mice by inducing plasma cell apoptosis independently of Tim-3. PLoS ONE 2013, 8, e60807. [CrossRef]

225. Gooden, M.J.; Wiersma, V.R.; Samplonius, D.F.; Gerssen, J.; van Ginkel, R.J.; Nijman, H.W.; Hirashima, M.; Niki, T.; Eggleton, P.; Helfrich, W.; et al. Galectin-9 activates and expands human T-helper 1 cells. PLoS ONE 2013, 8, e65616. [CrossRef] [PubMed]

226. Lhuillier, C.; Barjon, C.; Niki, T.; Gelin, A.; Praz, F.; Morales, O.; Souquere, S.; Hirashima, M.; Wei, M.; Dellis, O.; et al. Impact of exogenous galectin-9 on human t cells: Contribution of the t cell receptor complex to antigen-independent activation but not to apoptosis induction. J. Biol. Chem. 2015, 290, 16797-16811. [CrossRef]

227. Su, E.W.; Bi, S.; Kane, L.P. Galectin-9 regulates T helper cell function independently of Tim-3. Glycobiology 2011, 21, $1258-1265$. [CrossRef] [PubMed]

228. Dai, S.Y.; Nakagawa, R.; Itoh, A.; Murakami, H.; Kashio, Y.; Abe, H.; Katoh, S.; Kontani, K.; Kihara, M.; Zhang, S.L.; et al. Galectin-9 induces maturation of human monocyte-derived dendritic cells. J. Immunol. 2005, 175, 2974-2981. [CrossRef]

229. Chen, H.Y.; Wu, Y.F.; Chou, F.C.; Wu, Y.H.; Yeh, L.T.; Lin, K.I.; Liu, F.T.; Sytwu, H.K. Intracellular Galectin-9 Enhances Proximal TCR Signaling and Potentiates Autoimmune Diseases. J. Immunol. 2020, 204, 1158-1172. [CrossRef] [PubMed]

230. Oomizu, S.; Arikawa, T.; Niki, T.; Kadowaki, T.; Ueno, M.; Nishi, N.; Yamauchi, A.; Hattori, T.; Masaki, T.; Hirashima, M. Cell surface galectin-9 expressing th cells regulate Th17 and Foxp3+ Treg development by galectin-9 secretion. PLoS ONE 2012, 7, e48574. [CrossRef]

231. Oomizu, S.; Arikawa, T.; Niki, T.; Kadowaki, T.; Ueno, M.; Nishi, N.; Yamauchi, A.; Hirashima, M. Galectin-9 suppresses Th17 cell development in an IL-2-dependent but Tim-3-independent manner. Clin. Immunol. 2012, 143, 51-58. [CrossRef] [PubMed]

232. Shahbaz, S.; Dunsmore, G.; Koleva, P.; Xu, L.; Houston, S.; Elahi, S. Galectin-9 and VISTA Expression Define Terminally Exhausted T Cells in HIV-1 Infection. J. Immunol. 2020, 204, 2474-2491. [CrossRef]

233. Dardalhon, V.; Anderson, A.C.; Karman, J.; Apetoh, L.; Chandwaskar, R.; Lee, D.H.; Cornejo, M.; Nishi, N.; Yamauchi, A.; Quintana, F.J.; et al. Tim-3/galectin-9 pathway: Regulation of Th1 immunity through promotion of CD11b+Ly-6G+ myeloid cells. J. Immunol. 2010, 185, 1383-1392. [CrossRef]

234. Wang, F.; Wan, L.; Zhang, C.; Zheng, X.; Li, J.; Chen, Z.K. Tim-3-Galectin-9 pathway involves the suppression induced by CD4+CD25+ regulatory T cells. Immunobiology 2009, 214, 342-349. [CrossRef]

235. San Jose, E.; Borroto, A.; Niedergang, F.; Alcover, A.; Alarcon, B. Triggering the TCR complex causes the downregulation of nonengaged receptors by a signal transduction-dependent mechanism. Immunity 2000, 12, 161-170. [CrossRef] 
236. Galon, J.; Costes, A.; Sanchez-Cabo, F.; Kirilovsky, A.; Mlecnik, B.; Lagorce-Pages, C.; Tosolini, M.; Camus, M.; Berger, A.; Wind, P.; et al. Type, density, and location of immune cells within human colorectal tumors predict clinical outcome. Science 2006, 313, 1960-1964. [CrossRef]

237. Hwang, W.T.; Adams, S.F.; Tahirovic, E.; Hagemann, I.S.; Coukos, G. Prognostic significance of tumor-infiltrating T cells in ovarian cancer: A meta-analysis. Gynecol. Oncol. 2012, 124, 192-198. [CrossRef] [PubMed]

238. Joyce, J.A.; Fearon, D.T. T cell exclusion, immune privilege, and the tumor microenvironment. Science 2015, 348, 74-80. [CrossRef] [PubMed]

239. Banh, A.; Zhang, J.; Cao, H.; Bouley, D.M.; Kwok, S.; Kong, C.; Giaccia, A.J.; Koong, A.C.; Le, Q.T. Tumor galectin-1 mediates tumor growth and metastasis through regulation of T-cell apoptosis. Cancer Res. 2011, 71, 4423-4431. [CrossRef] [PubMed]

240. Mathieu, V.; de Lassalle, E.M.; Toelen, J.; Mohr, T.; Bellahcene, A.; Van Goietsenoven, G.; Verschuere, T.; Bouzin, C.; Debyser, Z.; De Vleeschouwer, S.; et al. Galectin-1 in melanoma biology and related neo-angiogenesis processes. J. Investig. Derm. 2012, 132, 2245-2254. [CrossRef]

241. Cedeno-Laurent, F.; Opperman, M.J.; Barthel, S.R.; Hays, D.; Schatton, T.; Zhan, Q.; He, X.; Matta, K.L.; Supko, J.G.; Frank, M.H.; et al. Metabolic inhibition of galectin-1-binding carbohydrates accentuates antitumor immunity. J. Investig. Derm. 2012, 132, 410-420. [CrossRef]

242. Martinez-Bosch, N.; Fernandez-Barrena, M.G.; Moreno, M.; Ortiz-Zapater, E.; Munne-Collado, J.; Iglesias, M.; Andre, S.; Gabius, H.J.; Hwang, R.F.; Poirier, F.; et al. Galectin-1 drives pancreatic carcinogenesis through stroma remodeling and Hedgehog signaling activation. Cancer Res. 2014, 74, 3512-3524. [CrossRef] [PubMed]

243. Rutkowski, M.R.; Stephen, T.L.; Svoronos, N.; Allegrezza, M.J.; Tesone, A.J.; Perales-Puchalt, A.; Brencicova, E.; Escovar-Fadul, X.; Nguyen, J.M.; Cadungog, M.G.; et al. Microbially driven TLR5-dependent signaling governs distal malignant progression through tumor-promoting inflammation. Cancer Cell. 2015, 27, 27-40. [CrossRef] [PubMed]

244. Endharti, A.T.; Zhou, Y.W.; Nakashima, I.; Suzuki, H. Galectin-1 supports survival of naive T cells without promoting cell proliferation. Eur. J. Immunol. 2005, 35, 86-97. [CrossRef] [PubMed]

245. Toscano, M.A.; Bianco, G.A.; Ilarregui, J.M.; Croci, D.O.; Correale, J.; Hernandez, J.D.; Zwirner, N.W.; Poirier, F.; Riley, E.M.; Baum, L.G.; et al. Differential glycosylation of TH1, TH2 and TH-17 effector cells selectively regulates susceptibility to cell death. Nat. Immunol. 2007, 8, 825-834. [CrossRef]

246. Stowell, S.R.; Qian, Y.; Karmakar, S.; Koyama, N.S.; Dias-Baruffi, M.; Leffler, H.; McEver, R.P.; Cummings, R.D. Differential roles of galectin-1 and galectin-3 in regulating leukocyte viability and cytokine secretion. J. Immunol. 2008, 180, 3091-3102. [CrossRef]

247. Yang, Y.; Karakhanova, S.; Werner, J.; Bazhin, A.V. Reactive oxygen species in cancer biology and anticancer therapy. Curr. Med. Chem. 2013, 20, 3677-3692. [CrossRef]

248. Cho, M.; Cummings, R.D. Galectin-1, a beta-galactoside-binding lectin in Chinese hamster ovary cells. II. Localization and biosynthesis. J. Biol. Chem. 1995, 270, 5207-5212. [CrossRef]

249. Fajka-Boja, R.; Blasko, A.; Kovacs-Solyom, F.; Szebeni, G.J.; Toth, G.K.; Monostori, E. Co-localization of galectin-1 with GM1 ganglioside in the course of its clathrin- and raft-dependent endocytosis. Cell. Mol. Life Sci. 2008, 65, 2586-2593. [CrossRef] [PubMed]

250. Valenzuela, H.F.; Pace, K.E.; Cabrera, P.V.; White, R.; Porvari, K.; Kaija, H.; Vihko, P.; Baum, L.G. O-glycosylation regulates LNCaP prostate cancer cell susceptibility to apoptosis induced by galectin-1. Cancer Res. 2007, 67, 6155-6162. [CrossRef] [PubMed]

251. Kovacs-Solyom, F.; Blasko, A.; Fajka-Boja, R.; Katona, R.L.; Vegh, L.; Novak, J.; Szebeni, G.J.; Krenacs, L.; Uher, F.; Tubak, V.; et al. Mechanism of tumor cell-induced T-cell apoptosis mediated by galectin-1. Immunol. Lett. 2010, 127, 108-118. [CrossRef]

252. Blasko, A.; Fajka-Boja, R.; Ion, G.; Monostori, E. How does it act when soluble? Critical evaluation of mechanism of galectin-1 induced T-cell apoptosis. Acta Biol. Hung. 2011, 62, 106-111. [CrossRef] [PubMed]

253. Buchel, G.; Schulte, J.H.; Harrison, L.; Batzke, K.; Schuller, U.; Hansen, W.; Schramm, A. Immune response modulation by Galectin-1 in a transgenic model of neuroblastoma. Oncoimmunology 2017, 5, e1131378. [CrossRef]

254. Thijssen, V.L.; Postel, R.; Brandwijk, R.J.; Dings, R.P.; Nesmelova, I.; Satijn, S.; Verhofstad, N.; Nakabeppu, Y.; Baum, L.G.; Bakkers, J.; et al. Galectin-1 is essential in tumor angiogenesis and is a target for antiangiogenesis therapy. Proc. Natl. Acad. Sci. USA 2006, 103, 15975-15980. [CrossRef]

255. Laderach, D.J.; Gentilini, L.D.; Giribaldi, L.; Delgado, V.C.; Nugnes, L.; Croci, D.O.; Al Nakouzi, N.; Sacca, P.; Casas, G.; Mazza, O.; et al. A Unique Galectin Signature in Human Prostate Cancer Progression Suggests Galectin-1 as a Key Target for Treatment of Advanced Disease. Cancer Res. 2013, 73, 86-96. [CrossRef]

256. Saussez, S.; Decaestecker, C.; Cludts, S.; Ernoux, P.; Chevalier, D.; Smetana, K., Jr.; Andre, S.; Leroy, X.; Gabius, H.J. Adhesion/growth-regulatory tissue lectin galectin-1 in relation to angiogenesis/lymphocyte infiltration and prognostic relevance of stromal up-regulation in laryngeal carcinomas. Anticancer Res. 2009, 29, 59-65. [PubMed]

257. Clausse, N.; van den Brule, F.; Waltregny, D.; Garnier, F.; Castronovo, V. Galectin-1 expression in prostate tumor-associated capillary endothelial cells is increased by prostate carcinoma cells and modulates heterotypic cell-cell adhesion. Angiogenesis 1999, 3, 317-325. [CrossRef] [PubMed]

258. Pranjol, M.Z.I.; Zinovkin, D.A.; Maskell, A.R.T.; Stephens, L.J.; Achinovich, S.L.; Los, D.M.; Nadyrov, E.A.; Hannemann, M.; Gutowski, N.J.; Whatmore, J.L. Cathepsin L-induced galectin-1 may act as a proangiogenic factor in the metastasis of high-grade serous carcinoma. J. Transl. Med. 2019, 17, 216. [CrossRef] [PubMed] 
259. Castillo-Gonzalez, R.; Cibrian, D.; Fernandez-Gallego, N.; Ramirez-Huesca, M.; Saiz, M.L.; Navarro, M.N.; Fresno, M.; de la Fuente, H.; Sanchez-Madrid, F. Galectin-1 Expression in CD8(+) T Lymphocytes Controls Inflammation in Contact Hypersensitivity. J. Investig. Derm. 2020, 141, 1522-1532. [CrossRef]

260. Deak, M.; Hornung, A.; Novak, J.; Demydenko, D.; Szabo, E.; Czibula, A.; Fajka-Boja, R.; Kriston-Pal, E.; Monostori, E.; Kovacs, L. Novel role for galectin-1 in T-cells under physiological and pathological conditions. Immunobiology 2015, 220, 483-489. [CrossRef]

261. Tanaka, A.; Sakaguchi, S. Regulatory T cells in cancer immunotherapy. Cell Res. 2017, 27, 109-118. [CrossRef]

262. Baatar, D.; Olkhanud, P.B.; Wells, V.; Indig, F.E.; Mallucci, L.; Biragyn, A. Tregs utilize beta-galactoside-binding protein to transiently inhibit PI3K/p21ras activity of human CD8+ T cells to block their TCR-mediated ERK activity and proliferation. Brain Behav. Immun. 2009, 23, 1028-1037. [CrossRef]

263. Lim, J.Y.; Kim, T.W.; Ryu, D.B.; Park, S.S.; Lee, S.E.; Kim, B.S.; Min, C.K. Myeloma-secreted galectin-1 potently interacts with CD304 on monocytic myeloid-derived suppressor cells. Cancer Immunol. Res. 2021, 9, 503-513. [CrossRef]

264. Blouin, C.M.; Hamon, Y.; Gonnord, P.; Boularan, C.; Kagan, J.; Viaris de Lesegno, C.; Ruez, R.; Mailfert, S.; Bertaux, N.; Loew, D.; et al. Glycosylation-Dependent IFN-gammaR Partitioning in Lipid and Actin Nanodomains Is Critical for JAK Activation. Cell 2016, 166, 920-934. [CrossRef]

265. Demotte, N.; Wieers, G.; Van Der Smissen, P.; Moser, M.; Schmidt, C.; Thielemans, K.; Squifflet, J.L.; Weynand, B.; Carrasco, J.; Lurquin, C.; et al. A galectin-3 ligand corrects the impaired function of human CD4 and CD8 tumor-infiltrating lymphocytes and favors tumor rejection in mice. Cancer Res. 2010, 70, 7476-7488. [CrossRef]

266. Woo, S.R.; Turnis, M.E.; Goldberg, M.V.; Bankoti, J.; Selby, M.; Nirschl, C.J.; Bettini, M.L.; Gravano, D.M.; Vogel, P.; Liu, C.L.; et al. Immune inhibitory molecules LAG-3 and PD-1 synergistically regulate T-cell function to promote tumoral immune escape. Cancer Res. 2012, 72, 917-927. [CrossRef] [PubMed]

267. Zubieta, M.R.; Furman, D.; Barrio, M.; Bravo, A.I.; Domenichini, E.; Mordoh, J. Galectin-3 expression correlates with apoptosis of tumor-associated lymphocytes in human melanoma biopsies. Am. J. Pathol. 2006, 168, 1666-1675. [CrossRef] [PubMed]

268. Gilson, R.C.; Gunasinghe, S.D.; Johannes, L.; Gaus, K. Galectin-3 modulation of T-cell activation: Mechanisms of membrane remodelling. Prog. Lipid. Res. 2019, 76, 101010. [CrossRef]

269. Jia, W.; Kidoya, H.; Yamakawa, D.; Naito, H.; Takakura, N. Galectin-3 accelerates M2 macrophage infiltration and angiogenesis in tumors. Am. J. Pathol. 2013, 182, 1821-1831. [CrossRef] [PubMed]

270. Demers, M.; Biron-Pain, K.; Hebert, J.; Lamarre, A.; Magnaldo, T.; St-Pierre, Y. Galectin-7 in lymphoma: Elevated expression in human lymphoid malignancies and decreased lymphoma dissemination by antisense strategies in experimental model. Cancer Res. 2007, 67, 2824-2829. [CrossRef] [PubMed]

271. Zhu, X.; Ding, M.; Yu, M.L.; Feng, M.X.; Tan, L.J.; Zhao, F.K. Identification of galectin-7 as a potential biomarker for esophageal squamous cell carcinoma by proteomic analysis. BMC Cancer 2010, 10, 290. [CrossRef]

272. Cada, Z.; Chovanec, M.; Smetana, K.; Betka, J.; Lacina, L.; Plzak, J.; Kodet, R.; Stork, J.; Lensch, M.; Kaltner, H.; et al. Galectin-7: Will the lectin's activity establish clinical correlations in head and neck squamous cell and basal cell carcinomas? Histol. Histopathol. 2009, 24, 41-48. [CrossRef] [PubMed]

273. Demers, M.; Rose, A.A.; Grosset, A.A.; Biron-Pain, K.; Gaboury, L.; Siegel, P.M.; St-Pierre, Y. Overexpression of galectin-7, a myoepithelial cell marker, enhances spontaneous metastasis of breast cancer cells. Am. J. Pathol. 2010, 176, 3023-3031. [CrossRef]

274. Trebo, A.; Ditsch, N.; Kuhn, C.; Heidegger, H.H.; Zeder-Goess, C.; Kolben, T.; Czogalla, B.; Schmoeckel, E.; Mahner, S.; Jeschke, U.; et al. High Galectin-7 and Low Galectin-8 Expression and the Combination of both are Negative Prognosticators for Breast Cancer Patients. Cancers 2020, 12, 953. [CrossRef]

275. Schulz, H.; Schmoeckel, E.; Kuhn, C.; Hofmann, S.; Mayr, D.; Mahner, S.; Jeschke, U. Galectins-1, -3, and -7 Are Prognostic Markers for Survival of Ovarian Cancer Patients. Int. J. Mol. Sci. 2017, 18, 1230. [CrossRef] [PubMed]

276. Kim, H.J.; Jeon, H.K.; Lee, J.K.; Sung, C.O.; Do, I.G.; Choi, C.H.; Kim, T.J.; Kim, B.G.; Bae, D.S.; Lee, J.W. Clinical significance of galectin-7 in epithelial ovarian cancer. Anticancer Res. 2013, 33, 1555-1561.

277. Pergialiotis, V.; Papoutsi, E.; Androutsou, A.; Tzortzis, A.S.; Frountzas, M.; Papapanagiotou, A.; Kontzoglou, K. Galectins-1, -3, -7, -8 and -9 as prognostic markers for survival in epithelial ovarian cancer: A systematic review and meta-analysis. Int. J. Gynaecol. Obs. 2021, 152, 299-307. [CrossRef]

278. Higareda-Almaraz, J.C.; Ruiz-Moreno, J.S.; Klimentova, J.; Barbieri, D.; Salvador-Gallego, R.; Ly, R.; Valtierra-Gutierrez, I.A.; Dinsart, C.; Rabinovich, G.A.; Stulik, J.; et al. Systems-level effects of ectopic galectin-7 reconstitution in cervical cancer and its microenvironment. BMC Cancer 2016, 16, 680. [CrossRef]

279. Bibens-Laulan, N.; St-Pierre, Y. Intracellular galectin-7 expression in cancer cells results from an autocrine transcriptional mechanism and endocytosis of extracellular galectin-7. PLoS ONE 2017, 12, e0187194. [CrossRef]

280. Labrie, M.; Vladoiu, M.C.; Grosset, A.A.; Gaboury, L.; St-Pierre, Y. Expression and functions of galectin-7 in ovarian cancer. Oncotarget 2014, 5, 7705-7721. [CrossRef]

281. Yamaguchi, T.; Hiromasa, K.; Kabashima-Kubo, R.; Yoshioka, M.; Nakamura, M. Galectin-7, induced by cis-urocanic acid and ultraviolet B irradiation, down-modulates cytokine production by T lymphocytes. Exp. Derm. 2013, 22, 840-842. [CrossRef]

282. Gentilini, L.D.; Jaworski, F.M.; Tiraboschi, C.; Perez, I.G.; Kotler, M.L.; Chauchereau, A.; Laderach, D.J.; Compagno, D. Stable and high expression of Galectin-8 tightly controls metastatic progression of prostate cancer. Oncotarget 2017, 8, 44654-44668. [CrossRef] 
283. Meinohl, C.; Barnard, S.J.; Fritz-Wolf, K.; Unger, M.; Porr, A.; Heipel, M.; Wirth, S.; Madlung, J.; Nordheim, A.; Menke, A.; et al. Galectin-8 binds to the Farnesylated C-terminus of K-Ras4B and Modifies Ras/ERK Signaling and Migration in Pancreatic and Lung Carcinoma Cells. Cancers 2019, 12, 30. [CrossRef]

284. Ferragut, F.; Cagnoni, A.J.; Colombo, L.L.; Sanchez Terrero, C.; Wolfenstein-Todel, C.; Troncoso, M.F.; Vanzulli, S.I.; Rabinovich, G.A.; Marino, K.V.; Elola, M.T. Dual knockdown of Galectin-8 and its glycosylated ligand, the activated leukocyte cell adhesion molecule (ALCAM/CD166), synergistically delays in vivo breast cancer growth. Biochim. Biophys. Acta Mol. Cell. Res. 2019, 1866, 1338-1352. [CrossRef]

285. Shatz-Azoulay, H.; Vinik, Y.; Isaac, R.; Kohler, U.; Lev, S.; Zick, Y. The Animal Lectin Galectin-8 Promotes Cytokine Expression and Metastatic Tumor Growth in Mice. Sci. Rep. 2020, 10, 7375. [CrossRef]

286. Norambuena, A.; Metz, C.; Vicuna, L.; Silva, A.; Pardo, E.; Oyanadel, C.; Massardo, L.; Gonzalez, A.; Soza, A. Galectin-8 induces apoptosis in Jurkat $\mathrm{T}$ cells by phosphatidic acid-mediated ERK1/2 activation supported by protein kinase A down-regulation. J. Biol. Chem. 2009, 284, 12670-12679. [CrossRef]

287. Cattaneo, V.; Tribulatti, M.V.; Campetella, O. Galectin-8 tandem-repeat structure is essential for T-cell proliferation but not for co-stimulation. Biochem. J. 2011, 434, 153-160. [CrossRef] [PubMed]

288. Zhou, X.; Sun, L.; Jing, D.; Xu, G.; Zhang, J.; Lin, L.; Zhao, J.; Yao, Z.; Lin, H. Galectin-9 Expression Predicts Favorable Clinical Outcome in Solid Tumors: A Systematic Review and Meta-Analysis. Front. Physiol. 2018, 9, 452. [CrossRef]

289. Irie, A.; Yamauchi, A.; Kontani, K.; Kihara, M.; Liu, D.; Shirato, Y.; Seki, M.; Nishi, N.; Nakamura, T.; Yokomise, H.; et al. Galectin-9 as a prognostic factor with antimetastatic potential in breast cancer. Clin. Cancer Res. 2005, 11, 2962-2968. [CrossRef]

290. Yamauchi, A.; Kontani, K.; Kihara, M.; Nishi, N.; Yokomise, H.; Hirashima, M. Galectin-9, a novel prognostic factor with antimetastatic potential in breast cancer. Breast J. 2006, 12, S196-S200. [CrossRef] [PubMed]

291. Fujita, K.; Iwama, H.; Sakamoto, T.; Okura, R.; Kobayashi, K.; Takano, J.; Katsura, A.; Tatsuta, M.; Maeda, E.; Mimura, S.; et al. Galectin-9 suppresses the growth of hepatocellular carcinoma via apoptosis in vitro and in vivo. Int. J. Oncol. 2015, 46, 2419-2430. [CrossRef] [PubMed]

292. De Mingo Pulido, A.; Gardner, A.; Hiebler, S.; Soliman, H.; Rugo, H.S.; Krummel, M.F.; Coussens, L.M.; Ruffell, B. TIM-3 Regulates CD103(+) Dendritic Cell Function and Response to Chemotherapy in Breast Cancer. Cancer Cell. 2018, 33, 60-74.e6. [CrossRef] [PubMed]

293. Headley, M.B.; Bins, A.; Nip, A.; Roberts, E.W.; Looney, M.R.; Gerard, A.; Krummel, M.F. Visualization of immediate immune responses to pioneer metastatic cells in the lung. Nature 2016, 531, 513-517. [CrossRef] [PubMed]

294. Roberts, E.W.; Broz, M.L.; Binnewies, M.; Headley, M.B.; Nelson, A.E.; Wolf, D.M.; Kaisho, T.; Bogunovic, D.; Bhardwaj, N.; Krummel, M.F. Critical Role for CD103(+)/CD141(+) Dendritic Cells Bearing CCR7 for Tumor Antigen Trafficking and Priming of T Cell Immunity in Melanoma. Cancer Cell. 2016, 30, 324-336. [CrossRef]

295. Salmon, H.; Idoyaga, J.; Rahman, A.; Leboeuf, M.; Remark, R.; Jordan, S.; Casanova-Acebes, M.; Khudoynazarova, M.; Agudo, J.; Tung, N.; et al. Expansion and Activation of CD103(+) Dendritic Cell Progenitors at the Tumor Site Enhances Tumor Responses to Therapeutic PD-L1 and BRAF Inhibition. Immunity 2016, 44, 924-938. [CrossRef]

296. Broz, M.L.; Binnewies, M.; Boldajipour, B.; Nelson, A.E.; Pollack, J.L.; Erle, D.J.; Barczak, A.; Rosenblum, M.D.; Daud, A.; Barber, D.L.; et al. Dissecting the tumor myeloid compartment reveals rare activating antigen-presenting cells critical for T cell immunity. Cancer Cell. 2014, 26, 638-652. [CrossRef]

297. Daley, D.; Mani, V.R.; Mohan, N.; Akkad, N.; Ochi, A.; Heindel, D.W.; Lee, K.B.; Zambirinis, C.P.; Pandian, G.S.B.; Savadkar, S.; et al. Dectin 1 activation on macrophages by galectin 9 promotes pancreatic carcinoma and peritumoral immune tolerance. Nat. Med. 2017, 23, 556-567. [CrossRef] [PubMed]

298. Mrizak, D.; Martin, N.; Barjon, C.; Jimenez-Pailhes, A.S.; Mustapha, R.; Niki, T.; Guigay, J.; Pancre, V.; de Launoit, Y.; Busson, P.; et al. Effect of nasopharyngeal carcinoma-derived exosomes on human regulatory T cells. J. Natl. Cancer Inst. 2015, 107, 363. [CrossRef]

299. Yan, J.; Zhang, Y.; Zhang, J.P.; Liang, J.; Li, L.; Zheng, L. Tim-3 expression defines regulatory T cells in human tumors. PLoS ONE 2013, 8, e58006. [CrossRef]

300. Sakuishi, K.; Ngiow, S.F.; Sullivan, J.M.; Teng, M.W.; Kuchroo, V.K.; Smyth, M.J.; Anderson, A.C. TIM3(+)FOXP3(+) regulatory T cells are tissue-specific promoters of T-cell dysfunction in cancer. Oncoimmunology 2013, 2, e23849. [CrossRef]

301. Qi, Y.; Chang, Y.; Wang, Z.; Chen, L.; Kong, Y.; Zhang, P.; Liu, Z.; Zhou, Q.; Chen, Y.; Wang, J.; et al. Tumor-associated macrophages expressing galectin-9 identify immunoevasive subtype muscle-invasive bladder cancer with poor prognosis but favorable adjuvant chemotherapeutic response. Cancer Immunol. Immunother. 2019, 68, 2067-2080. [CrossRef]

302. Zhou, Q.; Munger, M.E.; Veenstra, R.G.; Weigel, B.J.; Hirashima, M.; Munn, D.H.; Murphy, W.J.; Azuma, M.; Anderson, A.C.; Kuchroo, V.K.; et al. Coexpression of Tim-3 and PD-1 identifies a CD8+ T-cell exhaustion phenotype in mice with disseminated acute myelogenous leukemia. Blood 2011, 117, 4501-4510. [CrossRef]

303. Li, Z.; Liu, X.; Guo, R.; Wang, P. TIM-3 plays a more important role than PD-1 in the functional impairments of cytotoxic T cells of malignant Schwannomas. Tumour Biol. 2017, 39, 1010428317698352. [CrossRef] [PubMed]

304. Clayton, K.L.; Haaland, M.S.; Douglas-Vail, M.B.; Mujib, S.; Chew, G.M.; Ndhlovu, L.C.; Ostrowski, M.A. T cell Ig and mucin domain-containing protein 3 is recruited to the immune synapse, disrupts stable synapse formation, and associates with receptor phosphatases. J. Immunol. 2014, 192, 782-791. [CrossRef] 
305. Sakuishi, K.; Apetoh, L.; Sullivan, J.M.; Blazar, B.R.; Kuchroo, V.K.; Anderson, A.C. Targeting Tim-3 and PD-1 pathways to reverse T cell exhaustion and restore anti-tumor immunity. J. Exp. Med. 2010, 207, 2187-2194. [CrossRef] [PubMed]

306. Thommen, D.S.; Koelzer, V.H.; Herzig, P.; Roller, A.; Trefny, M.; Dimeloe, S.; Kiialainen, A.; Hanhart, J.; Schill, C.; Hess, C.; et al. A transcriptionally and functionally distinct PD-1(+) CD8(+) T cell pool with predictive potential in non-small-cell lung cancer treated with PD-1 blockade. Nat. Med. 2018, 24, 994-1004. [CrossRef]

307. Li, H.; van der Leun, A.M.; Yofe, I.; Lubling, Y.; Gelbard-Solodkin, D.; van Akkooi, A.C.J.; van den Braber, M.; Rozeman, E.A.; Haanen, J.; Blank, C.U.; et al. Dysfunctional CD8 T Cells Form a Proliferative, Dynamically Regulated Compartment within Human Melanoma. Cell 2019, 176, 775-789.e18. [CrossRef]

308. Saxena, M.; van der Burg, S.H.; Melief, C.J.M.; Bhardwaj, N. Therapeutic cancer vaccines. Nat. Rev. Cancer 2021, 125, $3401-3412$. [CrossRef]

309. Curran, M.A.; Glisson, B.S. New Hope for Therapeutic Cancer Vaccines in the Era of Immune Checkpoint Modulation. Annu. Rev. Med. 2019, 70, 409-424. [CrossRef]

310. Tran, T.; Blanc, C.; Granier, C.; Saldmann, A.; Tanchot, C.; Tartour, E. Therapeutic cancer vaccine: Building the future from lessons of the past. Semin. Immunopathol. 2019, 41, 69-85. [CrossRef]

311. Seyrek, K.; Richter, M.; Lavrik, I.N. Decoding the sweet regulation of apoptosis: The role of glycosylation and galectins in apoptotic signaling pathways. Cell Death Differ. 2019, 26, 981-993. [CrossRef] [PubMed]

312. Zhang, H.; Liu, P.; Zhang, Y.; Han, L.; Hu, Z.; Cai, Z.; Cai, J. Inhibition of galectin-3 augments the antitumor efficacy of PD-L1 blockade in non-small-cell lung cancer. FEBS Open Bio 2021, 11, 911-920. [CrossRef] [PubMed]

313. Dings, R.P.; Williams, B.W.; Song, C.W.; Griffioen, A.W.; Mayo, K.H.; Griffin, R.J. Anginex synergizes with radiation therapy to inhibit tumor growth by radiosensitizing endothelial cells. Int. J. Cancer 2005, 115, 312-319. [CrossRef] [PubMed]

314. Navarro, P.; Martinez-Bosch, N.; Blidner, A.G.; Rabinovich, G.A. Impact of Galectins in Resistance to Anticancer Therapies. Clin. Cancer Res. 2020, 26, 6086-6101. [CrossRef] [PubMed]

315. Astorgues-Xerri, L.; Riveiro, M.E.; Tijeras-Raballand, A.; Serova, M.; Rabinovich, G.A.; Bieche, I.; Vidaud, M.; de Gramont, A.; Martinet, M.; Cvitkovic, E.; et al. OTX008, a selective small-molecule inhibitor of galectin-1, downregulates cancer cell proliferation, invasion and tumour angiogenesis. Eur. J. Cancer 2014, 50, 2463-2477. [CrossRef] [PubMed]

316. Fukumori, T.; Oka, N.; Takenaka, Y.; Nangia-Makker, P.; Elsamman, E.; Kasai, T.; Shono, M.; Kanayama, H.O.; Ellerhorst, J.; Lotan, R.; et al. Galectin-3 regulates mitochondrial stability and antiapoptotic function in response to anticancer drug in prostate cancer. Cancer Res. 2006, 66, 3114-3119. [CrossRef]

317. Le Mercier, M.; Lefranc, F.; Mijatovic, T.; Debeir, O.; Haibe-Kains, B.; Bontempi, G.; Decaestecker, C.; Kiss, R.; Mathieu, V. Evidence of galectin-1 involvement in glioma chemoresistance. Toxicol. Appl. Pharm. 2008, 229, 172-183. [CrossRef]

318. Danhier, F.; Messaoudi, K.; Lemaire, L.; Benoit, J.P.; Lagarce, F. Combined anti-Galectin-1 and anti-EGFR siRNA-loaded chitosanlipid nanocapsules decrease temozolomide resistance in glioblastoma: In vivo evaluation. Int. J. Pharm. 2015, 481, 154-161. [CrossRef]

319. Gao, J.; Wang, W. Knockdown of galectin-1 facilitated cisplatin sensitivity by inhibiting autophagy in neuroblastoma cells. Chem. Biol. Interact. 2019, 297, 50-56. [CrossRef]

320. Lin, C.I.; Whang, E.E.; Donner, D.B.; Jiang, X.; Price, B.D.; Carothers, A.M.; Delaine, T.; Leffler, H.; Nilsson, U.J.; Nose, V.; et al. Galectin-3 targeted therapy with a small molecule inhibitor activates apoptosis and enhances both chemosensitivity and radiosensitivity in papillary thyroid cancer. Mol. Cancer Res. 2009, 7, 1655-1662. [CrossRef]

321. Harazono, Y.; Kho, D.H.; Balan, V.; Nakajima, K.; Hogan, V.; Raz, A. Extracellular galectin-3 programs multidrug resistance through $\mathrm{Na}+/ \mathrm{K}+-\mathrm{ATPase}$ and P-glycoprotein signaling. Oncotarget 2015, 6, 19592-19604. [CrossRef]

322. Yeh, C.C.; Hsu, C.H.; Shao, Y.Y.; Ho, W.C.; Tsai, M.H.; Feng, W.C.; Chow, L.P. Integrated Stable Isotope Labeling by Amino Acids in Cell Culture (SILAC) and Isobaric Tags for Relative and Absolute Quantitation (iTRAQ) Quantitative Proteomic Analysis Identifies Galectin-1 as a Potential Biomarker for Predicting Sorafenib Resistance in Liver Cancer. Mol. Cell. Proteom. 2015, 14, 1527-1545. [CrossRef]

323. Zhang, P.F.; Li, K.S.; Shen, Y.H.; Gao, P.T.; Dong, Z.R.; Cai, J.B.; Zhang, C.; Huang, X.Y.; Tian, M.X.; Hu, Z.Q.; et al. Galectin-1 induces hepatocellular carcinoma EMT and sorafenib resistance by activating FAK/PI3K/AKT signaling. Cell Death Dis. 2016, 7 , e2201. [CrossRef]

324. Zhang, L.; Liu, X.; Tang, Z.; Li, X.; Wang, G. Reversal of galectin-1 gene silencing on resistance to cisplatin in human lung adenocarcinoma A549 cells. Biomed. Pharm. 2016, 83, 265-270. [CrossRef] [PubMed]

325. Chung, L.Y.; Tang, S.J.; Sun, G.H.; Chou, T.Y.; Yeh, T.S.; Yu, S.L.; Sun, K.H. Galectin-1 promotes lung cancer progression and chemoresistance by upregulating p38 MAPK, ERK, and cyclooxygenase-2. Clin. Cancer Res. 2012, 18, 4037-4047. [CrossRef]

326. Luo, W.; Song, L.; Chen, X.L.; Zeng, X.F.; Wu, J.Z.; Zhu, C.R.; Huang, T.; Tan, X.P.; Lin, X.M.; Yang, Q.; et al. Identification of galectin-1 as a novel mediator for chemoresistance in chronic myeloid leukemia cells. Oncotarget 2016, 7, 26709-26723. [CrossRef]

327. Chauhan, D.; Li, G.; Podar, K.; Hideshima, T.; Neri, P.; He, D.; Mitsiades, N.; Richardson, P.; Chang, Y.; Schindler, J.; et al. A novel carbohydrate-based therapeutic GCS-100 overcomes bortezomib resistance and enhances dexamethasone-induced apoptosis in multiple myeloma cells. Cancer Res. 2005, 65, 8350-8358. [CrossRef] [PubMed]

328. Oishi, T.; Itamochi, H.; Kigawa, J.; Kanamori, Y.; Shimada, M.; Takahashi, M.; Shimogai, R.; Kawaguchi, W.; Sato, S.; Terakawa, N. Galectin-3 may contribute to Cisplatin resistance in clear cell carcinoma of the ovary. Int. J. Gynecol. Cancer 2007, 17, 1040-1046. [CrossRef] 
329. Mirandola, L.; Yu, Y.; Cannon, M.J.; Jenkins, M.R.; Rahman, R.L.; Nguyen, D.D.; Grizzi, F.; Cobos, E.; Figueroa, J.A.; Chiriva-Internati, M. Galectin-3 inhibition suppresses drug resistance, motility, invasion and angiogenic potential in ovarian cancer. Gynecol. Oncol. 2014, 135, 573-579. [CrossRef]

330. Wang, D.; You, D.; Li, L. Galectin-3 regulates chemotherapy sensitivity in epithelial ovarian carcinoma via regulating mitochondrial function. J. Toxicol. Sci. 2019, 44, 47-56. [CrossRef]

331. Hossein, G.; Halvaei, S.; Heidarian, Y.; Dehghani-Ghobadi, Z.; Hassani, M.; Hosseini, H.; Naderi, N.; Sheikh Hassani, S. Pectasol-C Modified Citrus Pectin targets Galectin-3-induced STAT3 activation and synergize paclitaxel cytotoxic effect on ovarian cancer spheroids. Cancer Med. 2019, 8, 4315-4329. [CrossRef] [PubMed]

332. Wongkham, S.; Junking, M.; Wongkham, C.; Sripa, B.; Chur-In, S.; Araki, N. Suppression of galectin-3 expression enhances apoptosis and chemosensitivity in liver fluke-associated cholangiocarcinoma. Cancer Sci. 2009, 100, 2077-2084. [CrossRef]

333. Park, G.B.; Kim, D.J.; Kim, Y.S.; Lee, H.K.; Kim, C.W.; Hur, D.Y. Silencing of galectin-3 represses osteosarcoma cell migration and invasion through inhibition of FAK/Src/Lyn activation and beta-catenin expression and increases susceptibility to chemotherapeutic agents. Int. J. Oncol. 2015, 46, 185-194. [CrossRef] [PubMed]

334. Kobayashi, T.; Shimura, T.; Yajima, T.; Kubo, N.; Araki, K.; Wada, W.; Tsutsumi, S.; Suzuki, H.; Kuwano, H.; Raz, A. Transient silencing of galectin-3 expression promotes both in vitro and in vivo drug-induced apoptosis of human pancreatic carcinoma cells. Clin. Exp. Metastasis 2011, 28, 367-376. [CrossRef] [PubMed]

335. Xu, Y.; Gu, X.; Gong, M.; Guo, G.; Han, K.; An, R. Galectin-3 inhibition sensitizes human renal cell carcinoma cells to arsenic trioxide treatment. Cancer Biol. 2013, 14, 897-906. [CrossRef] [PubMed]

336. Kuroda, J.; Yamamoto, M.; Nagoshi, H.; Kobayashi, T.; Sasaki, N.; Shimura, Y.; Horiike, S.; Kimura, S.; Yamauchi, A.; Hirashima, M.; et al. Targeting activating transcription factor 3 by Galectin-9 induces apoptosis and overcomes various types of treatment resistance in chronic myelogenous leukemia. Mol. Cancer Res. 2010, 8, 994-1001. [CrossRef] [PubMed]

337. Jabbari, N.; Kenerson, H.L.; Lausted, C.; Yan, X.; Meng, C.; Sullivan, K.M.; Baloni, P.; Bergey, D.; Pillarisetty, V.G.; Hood, L.E.; et al. Modulation of Immune Checkpoints by Chemotherapy in Human Colorectal Liver Metastases. Cell. Rep. Med. 2020, 1, 100160. [CrossRef]

338. Cabioglu, N.; Onder, S.; Oner, G.; Karatay, H.; Tukenmez, M.; Muslumanoglu, M.; Igci, A.; Eralp, Y.; Aydiner, A.; Saip, P.; et al. TIM3 expression on TILs is associated with poor response to neoadjuvant chemotherapy in patients with locally advanced triple-negative breast cancer. BMC Cancer 2021, 21, 357. [CrossRef]

339. Cai, G.; Ma, X.; Chen, B.; Huang, Y.; Liu, S.; Yang, H.; Zou, W. Galectin-3 induces ovarian cancer cell survival and chemoresistance via TLR4 signaling activation. Tumour Biol. 2016, 37, 11883-11891. [CrossRef]

340. Kelly, M.G.; Alvero, A.B.; Chen, R.; Silasi, D.A.; Abrahams, V.M.; Chan, S.; Visintin, I.; Rutherford, T.; Mor, G. TLR-4 signaling promotes tumor growth and paclitaxel chemoresistance in ovarian cancer. Cancer Res. 2006, 66, 3859-3868. [CrossRef]

341. Upreti, M.; Jyoti, A.; Johnson, S.E.; Swindell, E.P.; Napier, D.; Sethi, P.; Chan, R.; Feddock, J.M.; Weiss, H.L.; O’Halloran, T.V.; et al. Radiation-enhanced therapeutic targeting of galectin-1 enriched malignant stroma in triple negative breast cancer. Oncotarget 2016, 7, 41559-41574. [CrossRef]

342. Kuo, P.; Le, Q.T. Galectin-1 links tumor hypoxia and radiotherapy. Glycobiology 2014, 24, 921-925. [CrossRef]

343. Lai, J.; Lu, D.; Zhang, C.; Zhu, H.; Gao, L.; Wang, Y.; Bao, R.; Zhao, Y.; Jia, B.; Wang, F.; et al. Noninvasive small-animal imaging of galectin-1 upregulation for predicting tumor resistance to radiotherapy. Biomaterials 2018, 158, 1-9. [CrossRef] [PubMed]

344. Upreti, M.; Jamshidi-Parsian, A.; Apana, S.; Berridge, M.; Fologea, D.A.; Koonce, N.A.; Henry, R.L.; Griffin, R.J. Radiation-induced galectin-1 by endothelial cells: A promising molecular target for preferential drug delivery to the tumor vasculature. J. Mol. Med. 2013, 91, 497-506. [CrossRef]

345. Chouaib, S.; Messai, Y.; Couve, S.; Escudier, B.; Hasmim, M.; Noman, M.Z. Hypoxia promotes tumor growth in linking angiogenesis to immune escape. Front. Immunol. 2012, 3, 21. [CrossRef] [PubMed]

346. Khan, K.A.; Kerbel, R.S. Improving immunotherapy outcomes with anti-angiogenic treatments and vice versa. Nat. Rev. Clin. Oncol. 2018, 15, 310-324. [CrossRef]

347. Bannoud, N.; Dalotto-Moreno, T.; Kindgard, L.; Garcia, P.A.; Blidner, A.G.; Marino, K.V.; Rabinovich, G.A.; Croci, D.O. Hypoxia Supports Differentiation of Terminally Exhausted CD8 T Cells. Front. Immunol. 2021, 12, 660944. [CrossRef] [PubMed]

348. Miller, B.C.; Sen, D.R.; Al Abosy, R.; Bi, K.; Virkud, Y.V.; LaFleur, M.W.; Yates, K.B.; Lako, A.; Felt, K.; Naik, G.S.; et al. Subsets of exhausted CD8(+) T cells differentially mediate tumor control and respond to checkpoint blockade. Nat. Immunol. 2019, 20, 326-336. [CrossRef]

349. Jain, R.K. Normalizing tumor microenvironment to treat cancer: Bench to bedside to biomarkers. J. Clin. Oncol. 2013, 31, 2205-2218. [CrossRef] [PubMed]

350. Koonce, N.A.; Griffin, R.J.; Dings, R.P.M. Galectin-1 Inhibitor OTX008 Induces Tumor Vessel Normalization and Tumor Growth Inhibition in Human Head and Neck Squamous Cell Carcinoma Models. Int. J. Mol. Sci. 2017, 18, 2671. [CrossRef]

351. Grosset, A.A.; Labrie, M.; Vladoiu, M.C.; Yousef, E.M.; Gaboury, L.; St-Pierre, Y. Galectin signatures contribute to the heterogeneity of breast cancer and provide new prognostic information and therapeutic targets. Oncotarget 2016, 7, 18183-18203. [CrossRef]

352. Labrie, M.; De Araujo, L.O.F.; Communal, L.; Mes-Masson, A.M.; St-Pierre, Y. Tissue and plasma levels of galectins in patients with high grade serous ovarian carcinoma as new predictive biomarkers. Sci. Rep. 2017, 7, 13244. [CrossRef] [PubMed]

353. Drake, C.G.; Doody, A.D.; Mihalyo, M.A.; Huang, C.T.; Kelleher, E.; Ravi, S.; Hipkiss, E.L.; Flies, D.B.; Kennedy, E.P.; Long, M.; et al. Androgen ablation mitigates tolerance to a prostate/prostate cancer-restricted antigen. Cancer Cell. 2005, 7, 239-249. [CrossRef] 
354. Obradovic, A.Z.; Dallos, M.C.; Zahurak, M.L.; Partin, A.W.; Schaeffer, E.M.; Ross, A.E.; Allaf, M.E.; Nirschl, T.R.; Liu, D.; Chapman, C.G.; et al. T-Cell Infiltration and Adaptive Treg Resistance in Response to Androgen Deprivation With or Without Vaccination in Localized Prostate Cancer. Clin. Cancer Res. 2020, 26, 3182-3192. [CrossRef]

355. Spallanzani, R.G.; Dalotto-Moreno, T.; Raffo Iraolagoitia, X.L.; Ziblat, A.; Domaica, C.I.; Avila, D.E.; Rossi, L.E.; Fuertes, M.B.; Battistone, M.A.; Rabinovich, G.A.; et al. Expansion of CD11b(+)Ly6G (+)Ly6C (int) cells driven by medroxyprogesterone acetate in mice bearing breast tumors restrains NK cell effector functions. Cancer Immunol. Immunother. 2013, 62, 1781-1795. [CrossRef] [PubMed]

356. Sequeira, G.R.; Sahores, A.; Dalotto-Moreno, T.; Perrotta, R.M.; Pataccini, G.; Vanzulli, S.I.; Polo, M.L.; Radisky, D.C.; Sartorius, C.A.; Novaro, V.; et al. Enhanced Antitumor Immunity via Endocrine Therapy Prevents Mammary Tumor Relapse and Increases Immune Checkpoint Blockade Sensitivity. Cancer Res. 2021, 81, 1375-1387. [CrossRef]

357. Blois, S.M.; Ilarregui, J.M.; Tometten, M.; Garcia, M.; Orsal, A.S.; Cordo-Russo, R.; Toscano, M.A.; Bianco, G.A.; Kobelt, P.; Handjiski, B.; et al. A pivotal role for galectin-1 in fetomaternal tolerance. Nat. Med. 2007, 13, 1450-1457. [CrossRef]

358. Ramhorst, R.E.; Giribaldi, L.; Fraccaroli, L.; Toscano, M.A.; Stupirski, J.C.; Romero, M.D.; Durand, E.S.; Rubinstein, N.; Blaschitz, A.; Sedlmayr, P.; et al. Galectin-1 confers immune privilege to human trophoblast: Implications in recurrent fetal loss. Glycobiology 2012, 22, 1374-1386. [CrossRef]

359. Zucchetti, M.; Bonezzi, K.; Frapolli, R.; Sala, F.; Borsotti, P.; Zangarini, M.; Cvitkovic, E.; Noel, K.; Ubezio, P.; Giavazzi, R.; et al. Pharmacokinetics and antineoplastic activity of galectin-1-targeting OTX008 in combination with sunitinib. Cancer Chemother. Pharm. 2013, 72, 879-887. [CrossRef]

360. Leung, Z.; Ko, F.C.F.; Tey, S.K.; Kwong, E.M.L.; Mao, X.; Liu, B.H.M.; Ma, A.P.Y.; Fung, Y.M.E.; Che, C.M.; Wong, D.K.H.; et al. Galectin-1 promotes hepatocellular carcinoma and the combined therapeutic effect of OTX008 galectin-1 inhibitor and sorafenib in tumor cells. J. Exp. Clin. Cancer Res. 2019, 38, 423. [CrossRef] [PubMed]

361. Kostic, M.; Dzopalic, T.; Marjanovic, G.; Urosevic, I.; Milosevic, I. Immunomodulatory effects of galectin-1 in patients with chronic lymphocytic leukemia. Cent. Eur J. Immunol. 2021, 46, 54-62. [CrossRef]

362. Limagne, E.; Richard, C.; Thibaudin, M.; Fumet, J.D.; Truntzer, C.; Lagrange, A.; Favier, L.; Coudert, B.; Ghiringhelli, F. Tim-3/galectin-9 pathway and mMDSC control primary and secondary resistances to PD-1 blockade in lung cancer patients. Oncoimmunology 2019, 8, e1564505. [CrossRef]

363. Li, X.; Luo, L.; Jiang, M.; Zhu, C.; Shi, Y.; Zhang, J.; Qin, B.; Luo, Z.; Guo, X.; Lu, Y.; et al. Cocktail strategy for 'cold' tumors therapy via active recruitment of CD8+ T cells and enhancing their function. J. Control. Release 2021, 334, 413-426. [CrossRef]

364. Vuong, L.; Kouverianou, E.; Rooney, C.M.; McHugh, B.J.; Howie, S.E.M.; Gregory, C.D.; Forbes, S.J.; Henderson, N.C.; Zetterberg, F.R.; Nilsson, U.J.; et al. An Orally Active Galectin-3 Antagonist Inhibits Lung Adenocarcinoma Growth and Augments Response to PD-L1 Blockade. Cancer Res. 2019, 79, 1480-1492. [CrossRef] [PubMed]

365. Curti, B.D.; Koguchi, Y.; Leidner, R.S.; Rolig, A.S.; Sturgill, E.R.; Sun, Z.; Wu, Y.; Rajamanickam, V.; Bernard, B.; Hilgart-Martiszus, I.; et al. Enhancing clinical and immunological effects of anti-PD-1 with belapectin, a galectin-3 inhibitor. $J$. Immunother. Cancer 2021, 9, e002371. [CrossRef] [PubMed]

366. Capalbo, C.; Scafetta, G.; Filetti, M.; Marchetti, P.; Bartolazzi, A. Predictive Biomarkers for Checkpoint Inhibitor-Based Immunotherapy: The Galectin-3 Signature in NSCLCs. Int. J. Mol. Sci. 2019, 20, 1607. [CrossRef] [PubMed]

367. Wu, X.; Li, J.; Connolly, E.M.; Liao, X.; Ouyang, J.; Giobbie-Hurder, A.; Lawrence, D.; McDermott, D.; Murphy, G.; Zhou, J.; et al. Combined Anti-VEGF and Anti-CTLA-4 Therapy Elicits Humoral Immunity to Galectin-1 Which Is Associated with Favorable Clinical Outcomes. Cancer Immunol. Res. 2017, 5, 446-454. [CrossRef]

368. Nanami, T.; Hoshino, I.; Shiratori, F.; Yajima, S.; Oshima, Y.; Suzuki, T.; Ito, M.; Hiwasa, T.; Kuwajima, A.; Shimada, H. Prevalence of serum galectin-1 autoantibodies in seven types of cancer: A potential biomarker. Mol. Clin. Oncol. 2021, 15, 179. [CrossRef] [PubMed]

369. Wu, X.; Giobbie-Hurder, A.; Connolly, E.M.; Li, J.; Liao, X.; Severgnini, M.; Zhou, J.; Rodig, S.; Hodi, F.S. Anti-CTLA-4 based therapy elicits humoral immunity to galectin-3 in patients with metastatic melanoma. Oncoimmunology 2018, 7, e1440930. [CrossRef]

370. Vladoiu, M.C.; Labrie, M.; Letourneau, M.; Egesborg, P.; Gagne, D.; Billard, E.; Grosset, A.A.; Doucet, N.; Chatenet, D.; St-Pierre, Y. Design of a peptidic inhibitor that targets the dimer interface of a prototypic galectin. Oncotarget 2015, 6, 40970-40980. [CrossRef] [PubMed]

371. Iurisci, I.; Cumashi, A.; Sherman, A.A.; Tsvetkov, Y.E.; Tinari, N.; Piccolo, E.; D’Egidio, M.; Adamo, V.; Natoli, C.; Rabinovich, G.A.; et al. Synthetic inhibitors of galectin-1 and -3 selectively modulate homotypic cell aggregation and tumor cell apoptosis. Anticancer Res. 2009, 29, 403-410.

372. Blanchard, H.; Yu, X.; Collins, P.M.; Bum-Erdene, K. Galectin-3 inhibitors: A patent review (2008-present). Expert Opin. Pat. 2014, 24, 1053-1065. [CrossRef]

373. Tellez-Sanz, R.; Garcia-Fuentes, L.; Vargas-Berenguel, A. Human galectin-3 selective and high affinity inhibitors. Present state and future perspectives. Curr. Med. Chem. 2013, 20, 2979-2990. [CrossRef] [PubMed]

374. Cagnoni, A.J.; Perez Saez, J.M.; Rabinovich, G.A.; Marino, K.V. Turning-Off Signaling by Siglecs, Selectins, and Galectins: Chemical Inhibition of Glycan-Dependent Interactions in Cancer. Front. Oncol. 2016, 6, 109. [CrossRef]

375. Cooper, D.N. Galectinomics: Finding themes in complexity. Biochim. Biophys. Acta 2002, 1572, 209-231. [CrossRef] 
376. Barondes, S.H.; Castronovo, V.; Cooper, D.N.; Cummings, R.D.; Drickamer, K.; Feizi, T.; Gitt, M.A.; Hirabayashi, J.; Hughes, C.; Kasai, K.; et al. Galectins: A family of animal beta-galactoside-binding lectins. Cell 1994, 76, 597-598. [CrossRef]

377. Inohara, H.; Raz, A. Effects of natural complex carbohydrate (citrus pectin) on murine melanoma cell properties related to galectin-3 functions. Glycoconj J. 1994, 11, 527-532. [CrossRef] [PubMed]

378. Cagnoni, A.J.; Kovensky, J.; Uhrig, M.L. Design and synthesis of hydrolytically stable multivalent ligands bearing thiodigalactoside analogues for peanut lectin and human galectin-3 binding. J. Org. Chem. 2014, 79, 6456-6467. [CrossRef]

379. Kocibalova, Z.; Guzyova, M.; Borovska, I.; Messingerova, L.; Copakova, L.; Sulova, Z.; Breier, A. Development of Multidrug Resistance in Acute Myeloid Leukemia Is Associated with Alterations of the LPHN1/GAL-9/TIM-3 Signaling Pathway. Cancers 2021, 13, 3629. [CrossRef] [PubMed]

380. Ito, K.; Scott, S.A.; Cutler, S.; Dong, L.F.; Neuzil, J.; Blanchard, H.; Ralph, S.J. Thiodigalactoside inhibits murine cancers by concurrently blocking effects of galectin-1 on immune dysregulation, angiogenesis and protection against oxidative stress. Angiogenesis 2011, 14, 293-307. [CrossRef]

381. Ito, K.; Ralph, S.J. Inhibiting galectin-1 reduces murine lung metastasis with increased CD4(+) and CD8 (+) T cells and reduced cancer cell adherence. Clin. Exp. Metastasis 2012, 29, 561-572. [CrossRef]

382. Amano, M.; Suzuki, M.; Andoh, S.; Monzen, H.; Terai, K.; Williams, B.; Song, C.W.; Mayo, K.H.; Hasegawa, T.; Dings, R.P.; et al. Antiangiogenesis therapy using a novel angiogenesis inhibitor, anginex, following radiation causes tumor growth delay. Int. J. Clin. Oncol. 2007, 12, 42-47. [CrossRef] [PubMed]

383. Dings, R.P.; Yokoyama, Y.; Ramakrishnan, S.; Griffioen, A.W.; Mayo, K.H. The designed angiostatic peptide anginex synergistically improves chemotherapy and antiangiogenesis therapy with angiostatin. Cancer Res. 2003, 63, 382-385.

384. Mayo, K.H.; Dings, R.P.; Flader, C.; Nesmelova, I.; Hargittai, B.; van der Schaft, D.W.; van Eijk, L.I.; Walek, D.; Haseman, J.; Hoye, T.R.; et al. Design of a partial peptide mimetic of anginex with antiangiogenic and anticancer activity. J. Biol. Chem. 2003, 278, 45746-45752. [CrossRef]

385. Dings, R.P.; Kumar, N.; Miller, M.C.; Loren, M.; Rangwala, H.; Hoye, T.R.; Mayo, K.H. Structure-based optimization of angiostatic agent 6DBF7, an allosteric antagonist of galectin-1. J. Pharm. Exp. 2013, 344, 589-599. [CrossRef] [PubMed]

386. Dings, R.P.; Van Laar, E.S.; Webber, J.; Zhang, Y.; Griffin, R.J.; Waters, S.J.; MacDonald, J.R.; Mayo, K.H. Ovarian tumor growth regression using a combination of vascular targeting agents anginex or topomimetic 0118 and the chemotherapeutic irofulven. Cancer Lett. 2008, 265, 270-280. [CrossRef]

387. Michael, J.V.; Wurtzel, J.G.; Goldfinger, L.E. Inhibition of Galectin-1 Sensitizes HRAS-driven Tumor Growth to Rapamycin Treatment. Anticancer Res. 2016, 36, 5053-5061. [CrossRef]

388. Ouyang, J.; Juszczynski, P.; Rodig, S.J.; Green, M.R.; O’Donnell, E.; Currie, T.; Armant, M.; Takeyama, K.; Monti, S.; Rabinovich, G.A.; et al. Viral induction and targeted inhibition of galectin-1 in EBV+ posttransplant lymphoproliferative disorders. Blood 2011, 117, 4315-4322. [CrossRef] [PubMed]

389. Perez Saez, J.M.; Hockl, P.F.; Cagnoni, A.J.; Mendez Huergo, S.P.; Garcia, P.A.; Gatto, S.G.; Cerliani, J.P.; Croci, D.O.; Rabinovich, G.A. Characterization of a neutralizing anti-human galectin-1 monoclonal antibody with angioregulatory and immunomodulatory activities. Angiogenesis 2021, 24, 1-5. [CrossRef] [PubMed]

390. Demotte, N.; Bigirimana, R.; Wieers, G.; Stroobant, V.; Squifflet, J.L.; Carrasco, J.; Thielemans, K.; Baurain, J.F.; Van Der Smissen, P.; Courtoy, P.J.; et al. A short treatment with galactomannan GM-CT-01 corrects the functions of freshly isolated human tumor-infiltrating lymphocytes. Clin. Cancer Res. 2014, 20, 1823-1833. [CrossRef] [PubMed]

391. Sturgill, E.R.; Rolig, A.S.; Linch, S.N.; Mick, C.; Kasiewicz, M.J.; Sun, Z.; Traber, P.G.; Shlevin, H.; Redmond, W.L. Galectin-3 inhibition with belapectin combined with anti-OX40 therapy reprograms the tumor microenvironment to favor anti-tumor immunity. Oncoimmunology 2021, 10, 1892265. [CrossRef] [PubMed]

392. Newton-Northup, J.R.; Dickerson, M.T.; Ma, L.; Besch-Williford, C.L.; Deutscher, S.L. Inhibition of metastatic tumor formation in vivo by a bacteriophage display-derived galectin-3 targeting peptide. Clin. Exp. Metastasis 2013, 30, 119-132. [CrossRef]

393. Yang, Y.; Zhou, Z.; He, S.; Fan, T.; Jin, Y.; Zhu, X.; Chen, C.; Zhang, Z.R.; Huang, Y. Treatment of prostate carcinoma with (galectin-3)-targeted HPMA copolymer-(G3-C12)-5-Fluorouracil conjugates. Biomaterials 2012, 33, 2260-2271. [CrossRef]

394. Yang, Y.; Li, L.; Zhou, Z.; Yang, Q.; Liu, C.; Huang, Y. Targeting prostate carcinoma by G3-C12 peptide conjugated N-(2hydroxypropyl)methacrylamide copolymers. Mol. Pharm. 2014, 11, 3251-3260. [CrossRef]

395. Yang, Q.; Yang, Y.; Li, L.; Sun, W.; Zhu, X.; Huang, Y. Polymeric nanomedicine for tumor-targeted combination therapy to elicit synergistic genotoxicity against prostate cancer. ACS Appl. Mater. Interfaces 2015, 7, 6661-6673. [CrossRef] [PubMed]

396. Sun, W.; Li, L.; Yang, Q.; Shan, W.; Zhang, Z.; Huang, Y. G3-C12 Peptide Reverses Galectin-3 from Foe to Friend for Active Targeting Cancer Treatment. Mol. Pharm. 2015, 12, 4124-4136. [CrossRef]

397. Platt, D.; Raz, A. Modulation of the lung colonization of B16-F1 melanoma cells by citrus pectin. J. Natl. Cancer Inst. 1992, 84, 438-442. [CrossRef] [PubMed]

398. Pienta, K.J.; Naik, H.; Akhtar, A.; Yamazaki, K.; Replogle, T.S.; Lehr, J.; Donat, T.L.; Tait, L.; Hogan, V.; Raz, A. Inhibition of spontaneous metastasis in a rat prostate cancer model by oral administration of modified citrus pectin. J. Natl. Cancer Inst. 1995, 87, 348-353. [CrossRef] [PubMed]

399. Hayashi, A.; Gillen, A.C.; Lott, J.R. Effects of daily oral administration of quercetin chalcone and modified citrus pectin on implanted colon-25 tumor growth in Balb-c mice. Altern. Med. Rev. 2000, 5, 546-552. 
400. Nangia-Makker, P.; Hogan, V.; Honjo, Y.; Baccarini, S.; Tait, L.; Bresalier, R.; Raz, A. Inhibition of human cancer cell growth and metastasis in nude mice by oral intake of modified citrus pectin. J. Natl. Cancer Inst. 2002, 94, 1854-1862. [CrossRef]

401. Liu, H.Y.; Huang, Z.L.; Yang, G.H.; Lu, W.Q.; Yu, N.R. Inhibitory effect of modified citrus pectin on liver metastases in a mouse colon cancer model. World J. Gastroenterol. 2008, 14, 7386-7391. [CrossRef]

402. Ramachandran, C.; Wilk, B.J.; Hotchkiss, A.; Chau, H.; Eliaz, I.; Melnick, S.J. Activation of human T-helper/inducer cell, Tcytotoxic cell, B-cell, and natural killer (NK)-cells and induction of natural killer cell activity against K562 chronic myeloid leukemia cells with modified citrus pectin. BMC Complement. Altern. Med. 2011, 11, 59. [CrossRef]

403. Yan, J.; Katz, A. PectaSol-C modified citrus pectin induces apoptosis and inhibition of proliferation in human and mouse androgen-dependent and- independent prostate cancer cells. Integr. Cancer 2010, 9, 197-203. [CrossRef]

404. Tehranian, N.; Sepehri, H.; Mehdipour, P.; Biramijamal, F.; Hossein-Nezhad, A.; Sarrafnejad, A.; Hajizadeh, E. Combination effect of PectaSol and Doxorubicin on viability, cell cycle arrest and apoptosis in DU-145 and LNCaP prostate cancer cell lines. Cell Biol. Int. 2012, 36, 601-610. [CrossRef] [PubMed]

405. Streetly, M.J.; Maharaj, L.; Joel, S.; Schey, S.A.; Gribben, J.G.; Cotter, F.E. GCS-100, a novel galectin-3 antagonist, modulates MCL-1, NOXA, and cell cycle to induce myeloma cell death. Blood 2010, 115, 3939-3948. [CrossRef] [PubMed]

406. Wang, Y.; Nangia-Makker, P.; Balan, V.; Hogan, V.; Raz, A. Calpain activation through galectin-3 inhibition sensitizes prostate cancer cells to cisplatin treatment. Cell Death Dis. 2010, 1, e101. [CrossRef] [PubMed]

407. Clark, M.C.; Pang, M.; Hsu, D.K.; Liu, F.T.; de Vos, S.; Gascoyne, R.D.; Said, J.; Baum, L.G. Galectin-3 binds to CD45 on diffuse large B-cell lymphoma cells to regulate susceptibility to cell death. Blood 2012, 120, 4635-4644. [CrossRef] [PubMed]

408. Ruvolo, P.P.; Ruvolo, V.R.; Benton, C.B.; AlRawi, A.; Burks, J.K.; Schober, W.; Rolke, J.; Tidmarsh, G.; Hail, N., Jr.; Davis, R.E.; et al. Combination of galectin inhibitor GCS-100 and BH3 mimetics eliminates both p53 wild type and p53 null AML cells. Biochim. Biophys. Acta 2016, 1863, 562-571. [CrossRef] 